University of Nebraska - Lincoln

DigitalCommons@University of Nebraska - Lincoln

\title{
$5-2008$
}

\section{Elk Calf Survival and Mortality Following Wolf Restoration to Yellowstone National Park}

Shannon M. Barber-Meyer

University of Minnesota, Saint Paul, sbarber-meyer@usgs.gov

L. David Mech

USGS Northern Prairie Wildlife Research Center, david_mech@usgs.gov

P. J. White

Yellowstone National Park

Follow this and additional works at: https://digitalcommons.unl.edu/usgsnpwrc

Part of the Other International and Area Studies Commons

Barber-Meyer, Shannon M.; Mech, L. David; and White, P. J., "Elk Calf Survival and Mortality Following Wolf Restoration to Yellowstone National Park" (2008). USGS Northern Prairie Wildlife Research Center. 96. https://digitalcommons.unl.edu/usgsnpwrc/96

This Article is brought to you for free and open access by the US Geological Survey at DigitalCommons@University of Nebraska - Lincoln. It has been accepted for inclusion in USGS Northern Prairie Wildlife Research Center by an authorized administrator of DigitalCommons@University of Nebraska - Lincoln. 


\title{
Elk Calf Survival and Mortality Following Wolf Restoration to Yellowstone National Park
}

\author{
SHANNON M. BARBER-MEYER, 1,2 Department of Fisheries, Wildlife, and Conservation Biology, 200 Hodson Hall, 1980 Folwell Avenue, \\ University of Minnesota, Saint Paul, MN 55108, USA \\ L. DAVID MECH, Northern Prairie Wildlife Research Center, United States Geological Survey, Jamestown, ND 58401, USA \\ P. J. WHITE, National Park Service, P.O. Box 168, Yellowstone National Park, WY 82190, USA
}

\begin{abstract}
We conducted a 3-year study (May 2003-Apr 2006) of mortality of northern Yellowstone elk (Cervus elaphus) calves to determine the cause for the recruitment decline (i.e., 33 calves to 13 calves/100 adult F) following the restoration of wolves (Canis lupus). We captured, fit with radiotransmitters, and evaluated blood characteristics and disease antibody seroprevalence in 151 calves $\leq 6$ days old (68M:83F). Concentrations $(\bar{x}$, SE) of potential condition indicators were as follows: thyroxine (T4; $13.8 \mu \mathrm{g} / \mathrm{dL}, 0.43$ ), serum urea nitrogen (SUN; $17.4 \mathrm{mg} / \mathrm{dL}, 0.57$ ), $\gamma$-glutamyltransferase (GGT; 66.4 IU/L, 4.36), gamma globulins (GG; $1.5 \mathrm{~g} / \mathrm{dL}, 0.07)$, and insulin-like growth factor-1 (IGF-1; $253.6 \mathrm{ng} / \mathrm{mL}, 9.59)$. Seroprevalences were as follows: brucellosis (Brucella abortus; 3\%), bovine-respiratory syncytial virus (3\%), bovine-viral-diarrhea virus type 1 (25\%), infectious-bovine rhinotracheitis (58\%), and bovine parainfluenza-3 (32\%). Serum urea nitrogen, GGT, GG, and IGF-1 varied with year; T4, SUN, and GG varied with age $(P \leq 0.01)$; and SUN varied by capture area $(P=0.02)$. Annual survival was $0.22(\mathrm{SE}=0.035, n=149)$ and varied by calving area but not year. Neonates captured in the Stephens Creek/Mammoth area of Yellowstone National Park, USA, had annual survival rates $>3 \times$ higher $(0.54)$ than those captured in the Lamar Valley area (0.17), likely due to the higher predator density in Lamar Valley. Summer survival (20 weeks after radiotagging) was $0.29(\mathrm{SE}=0.05, n=116)$, and calving area, absolute deviation from median birth date, and GG were important predictors of summer survival. Survival during winter (Nov-Apr) was $0.90(\mathrm{SE}=0.05, n=42)$, and it did not vary by calving area or year. Sixty-nine percent ( $n=104)$ of calves died within the first year of life, 24\% $(n=36)$ survived their first year, and 7\% ( $n=11)$ had unknown fates. Grizzly bears (Ursus arctos) and black bears (Ursus americanus) accounted for 58-60\% $(n=60-62)$ of deaths, and wolves accounted for $14-17 \%(n=15-18)$. Summer predation (95\% of summer deaths) increased, and winter malnutrition ( $0 \%$ of winter deaths) decreased, compared with a similar study during 1987-1990 (72\% and 58\%, respectively). Physiological factors (e.g., low levels of GG) may predispose calves to predation. Also, the increase in bear numbers since wolf restoration and spatial components finer than the northern range should be considered when trying to determine the causes of the northern Yellowstone elk decline. This is the first study to document the predation impacts from reintroduced wolves on elk calf mortality in an ecosystem already containing established populations of 4 other major predators (i.e., grizzly and black bears, cougars [Puma concolor], and coyotes [Canis latrans]). The results are relevant to resource managers of the Yellowstone ecosystem in understanding the dynamics of the elk population, in providing harvest quota recommendations for local elk hunts to the Montana Department of Fish, Wildlife and Parks, the United States Fish and Wildlife Service regarding wolf and grizzly bear recovery, and to all areas worldwide where predators are increasing, by providing managers with information about potential carnivore impacts on elk populations. (WILDLIFE MONOGRAPHS 169:1-30)
\end{abstract}

DOI: $10.2193 / 2008-004$

KEY WORDS Canis lupus, Cervus elaphus, elk, gamma globulins, mortality, predation, Ursus americanus, Ursus arctos, wolf, Yellowstone.

\section{La Supervivencia y la Mortalidad de las Crías de Wapiti Tras la Restauración del Lobo al Parque Nacional de Yellowstone}

\begin{abstract}
RESEMEN Hemos realizado un estudio de 3 años (may 2003-abr 2006) sobre la mortalidad de las crías de wapiti (Cervus elaphus) en el norte de Yellowstone para determinar las causas del descenso del reclutamiento (de 33 a 13 crías /100 hembras adultas) tras la restauración del lobo (Canis lupus). Hemos capturado, marcado con radiotransmisores y evaluado las características de la sangre y la seroprevalencia de los anticuerpos a enfermedades de 151 crías $\leq 6$ días (68M:83H). Las concentraciones $(\bar{x}, \mathrm{SE})$ de los indicadores del estado potencial de salud fueron: tiroxina (T4; $13.8 \mu \mathrm{g} / \mathrm{dL}, 0.43$ ), nitrógeno de urea en suero (SUN; $17.4 \mathrm{mg} / \mathrm{dL}$, 0.57), $\gamma$-glutamiltransferasa (GGT; $66.4 \mathrm{IU} / \mathrm{L}, 4.36$ ), gamma globulinas (GG; $1.5 \mathrm{~g} / \mathrm{dL}, 0.07$ ) y factor de crecimiento insulinoide tipo 1 (IGF-1; $253.6 \mathrm{ng} / \mathrm{mL}$, 9.59). Las seroprevalencias fueron: brucelosis (Brucella abortus; 3\%), virus respiratorio sincitial bovino (3\%), virus de la diarrea viral bovina tipo 1 (25\%), rinotraqueítis infecciosa bovina (58\%) y parainfluenza bovina tipo 3 (32\%). El SUN, la GGT, las GG y el IGF-1 variaron con el año; la T4, el SUN y las GG variaron con la edad $(P \leq 0.01)$; y el SUN varió con el área de captura $(P=0.02)$. La supervivencia anual fue del $0.22(\mathrm{SE}=0.035, n=149)$ y varió con la zona de reproducción pero no con el año. Los neonatos capturados en la zona de Stephens Creek/Mammoth del Parque Nacional de Yellowstone, EE.UU., tuvieron tasas de supervivencia anual más de 3 veces superiores (0.54) a las de los capturados en la zona del valle de Lamar (0.17), presumiblemente por la mayor densidad de predadores en el valle de Lamar. La supervivencia estival (20 semanas después del radiomarcaje) fue 0.29 ( $\mathrm{SE}=0.05, n=116)$; la zona de partos, la desviación absoluta de la mediana de la fecha de nacimiento y las GG fueron predictores importantes de la supervivencia estival. La supervivencia durante el invierno (nov-abr) fue $0.90(\mathrm{SE}=0.05, n=42)$ y no varió con la zona de partos o con el año. El $69 \%(n=104)$ de las crías murieron antes de cumplir un año, el 24\% $(n=36)$ sobrevivieron más de un año y se desconoce el destino del 7\% ( $n=11)$. Los osos grizzly (Ursus arctos) y los osos negros (Ursus americanus) fueron responsables del 58-60\% ( $n=60-$ 62) de las muertes, y los lobos, del 14-17\% ( $n=15-18)$. La predación estival ( $95 \%$ de las muertes en verano) aumentó, y la malnutrición en invierno (0\% de las muertes en invierno) disminuyó en comparación con un estudio similar realizado durante 1987-1990 (72\% y 58\%, respectivamente). Los factores fisiológicos (bajos niveles de GG) quizá predisponen a las crías a ser predadas. Además, el aumento de la población de osos desde la restauración del lobo y algunos componentes espaciales más sutiles en las montañas septentrionales deberían ser considerados al tratar de determinar las causas del declive del wapiti en el norte de Yellowstone. Este es el primer estudio que describe el impacto que la predación de lobos reintroducidos tiene sobre la mortalidad de las crías de wapiti en un ecosistema donde ya existen poblaciones establecidas de otros 4 grandes predadores (osos grizzly y negro, pumas [Puma concolor] y coyotes [Canis latrans]). Los resultados son relevantes para los gestores de recursos del ecosistema de Yellowstone porque ayudan a comprender la dinámica de las poblaciones de wapiti; aportan recomendaciones al Departamento de Pesca, Vida Silvestre y Parques de Montana para decidir cuotas de extracción de wapiti en las cacerías locales, al Servicio de Pesca y Vida Silvestre de los Estados Unidos en relación a la recuperación del lobo y el oso grizzly; y ofrecen a los gestores información acerca de los impactos potenciales de los carnívoros sobre las poblaciones de wapiti en todas las zonas del mundo donde los predadores están aumentando.
\end{abstract}

${ }^{1}$ E-mail: shannonbarbermeyer@gmail.com

2 Present address: The World Wildlife Fund, 1250 24th Street NW, Washington, D.C. 20037, USA 


\title{
La Survie et la Mortalité des Faons de Wapitis qui a Suivi la Réintroduction du Loup au Parc de Yellowstone
}

\begin{abstract}
RÉSUMÉ Nous avons réalisé une étude de 3 ans (mai 2003-avr 2006) portant sur les faons des wapitis du nord de Yellowstone afin de déterminer les causes du déclin de recrutement (c.-à-d. de 33 à 13 faons/100 femelles adultes) qui a suivi la réintroduction du loup (Canis lupus). Nous avons capturé, prélevé un échantillon sanguin et muni d'un radioémetteur 151 faons de $\leq 6$ jours (68M:83F). Les concentrations ( $\bar{x}, \mathrm{ET})$ d'indicateurs potentiels de condition physique étaient: thyroxine (T4; $13.8 \mu \mathrm{g} / \mathrm{dL}, 0.43$ ), azote uréique sérique (AUS; $17.4 \mathrm{mg} / \mathrm{dL}, 0.57$ ), $\gamma$-glutamyltransférase (GGT; 66.4 IU/L, 4.36), gamma globulines (GG; $1.5 \mathrm{~g} / \mathrm{dL}, 0.07)$ et facteur de croissance insulinomimétique de type 1 (FCI-1; $253.6 \mathrm{ng} / \mathrm{mL}, 9.59)$. La prévalence sérique d'anticorps était: brucellose (Brucella abortus; 3\%), virus syncitial respiratoire bovin (3\%), virus diarrhéique bovin de type 1 (25\%), rhinotrachéite infectieuse bovine (58\%) et parainfluenza-3 bovin (32\%). L'azote uréique sérique, la GGT, les GG et le FCI-1 ont varié entre les années; la T4, l'AUS et les GG varièrent en fonction de l'âge $(P \leq 0.01)$ et l'AUS en fonction du lieu de capture $(P=0.02)$. Le taux annuel de survie atteignit $0.22(\mathrm{ET}=0.035, n=149)$ et varia en fonction de l'aire de mise bas mais non de l'année. Les faons nés dans l'aire de Stephens Creek/Mammoth du parc national de Yellowstone, États-Unis, possédaient des taux annuels de survie plus de 3 fois supérieurs (0.54) à ceux capturés dans l'aire de Lamar Valley (0.17), vraisemblablement à cause d'une densité de prédateurs plus élevée au second endroit. La survie estivale moyenne (20 semaines suivant le marquage) était de $0.29(\mathrm{ET}=0.05, n=116)$ et elle dépendait fortement du lieu de mise bas, de la déviation absolue de la date de naissance médiane et de la concentration de GG. La survie hivernale (nov-avr) atteignait 0.90 (ET $=0.05, n$ $=42)$ et ne variait ni en fonction du lieu de naissance ou de l'année. Soixante-neuf pourcent $(n=104)$ des faons moururent durant leur première année, $24 \%(n$ $=36)$ survécurent et le sort de 7\% $(n=11)$ demeura inconnu. Les ours grizzlys (Ursus arctos) et les ours noirs (Ursus americanus) furent responsables de 58-60\% des mortalités $(n=60-62)$, contre $14-17 \%$ pour les loups $(n=15-18)$. La prédation estivale ( $95 \%$ des mortalités) augmenta et la malnutrition hivernale $(0 \%$ des mortalités) diminua en comparaison avec une étude similaire réalisée de 1987 à 1990 (72\% et 58\%, respectivement). Des facteurs physiologiques (c.-à-d. des bas niveaux de GG) pourraient prédisposer les faons à la prédation. Par ailleurs, l'accroissement du nombre d'ours depuis la réintroduction du loup et des composantes spatiales plus fines que celles de notre étude devraient être pris en compte en tentant de déterminer les causes du déclin du nombre de wapitis du nord de Yellowstone. Notre étude s'avère la première à documenter les impacts de la prédation de loups réintroduits dans un écosystème contenant des populations établies de 4 prédateurs majeurs (c.-à-d., les ours grizzlys et noirs, les cougars [Puma concolor], les coyotes [Canis latrans]). Nos résultats concernent les gestionnaires de l'écosystème de Yellowstone puisqu'ils permettent de comprendre la dynamique de la population de wapitis, qu'ils fournissent des recommandations pour les chasses locales au Montana Department of Fish, Wildlife and Parks et d'autres, pour la gestion du loup et de l'ours grizzly, au U.S. Fish and Wildlife Service. Nos résultats concernent également toutes les régions du monde où les prédateurs s'accroissent puisqu'ils fournissent aux gestionnaires des informations concernant l'impact potentiel des carnivores sur les populations de grands herbivores.
\end{abstract}

\section{Contents}

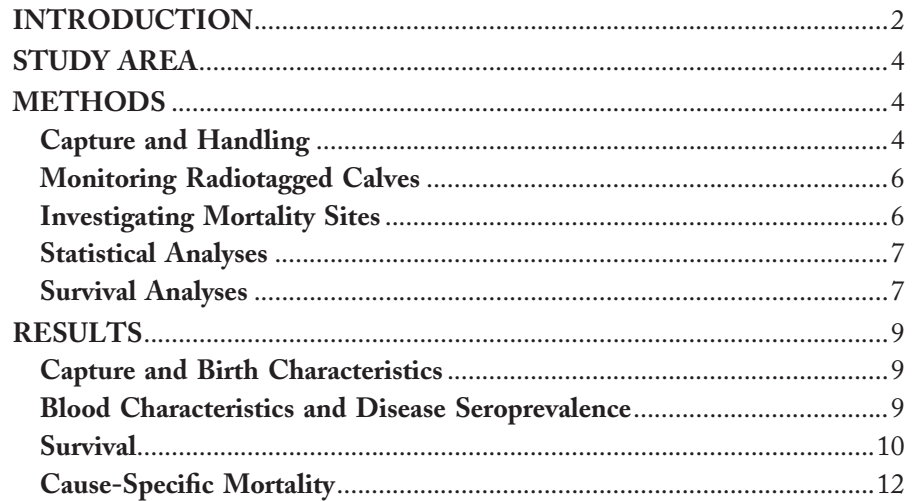

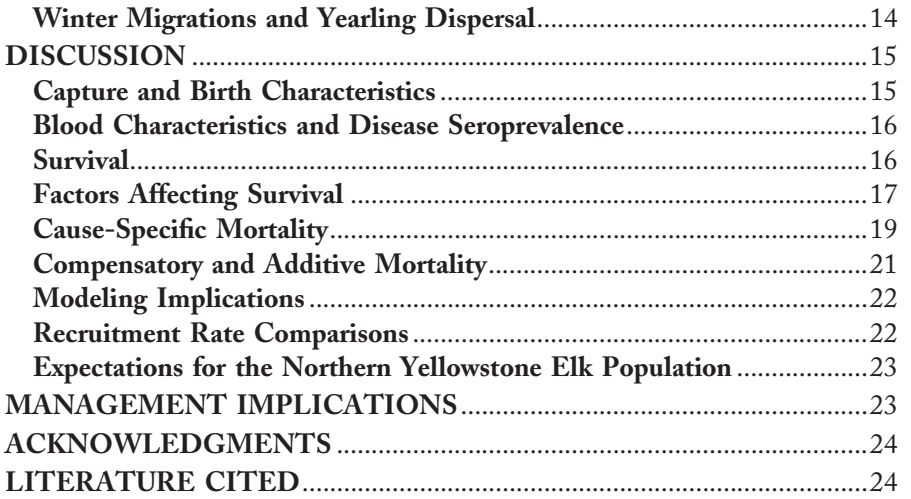

\section{INTRODUCTION}

Sixty years after the elimination of gray wolves (Canis lupus) from Yellowstone National Park (YNP), USA, in the 1930s (Weaver 1978), 31 wolves from western Canada were released in YNP during 1995-1996 (Bangs and Fritts 1996, Phillips and Smith 1996). Before wolf restoration, predictions were made about potential impacts to elk abundance and distribution (Yellowstone National Park et al. 1990, Varley and Brewster 1992, Cook 1993, U.S. Fish and Wildlife Service 1994, Messier et al. 1995). Predictions centered on the northern Yellowstone elk herd (elk that winter "on the Yellowstone River drainage in and adjacent to the park," Houston 1982:1), the largest and most studied elk herd residing in YNP. Although most models indicated elk abundance would decrease 5-30\% after wolf restoration (Boyce and Gaillard 1992; Boyce 1993; Mack and Singer 1992, 1993a, b), Messier et al. (1995) predicted greater declines due to the diverse predator suite and hunting pressure. Indeed, elk annual counts on the northern range declined 50\% from 19,045 in 1994 to 9,545 in 2005, as wolf numbers in this area increased to a high of 106 in 2004 (White and Garrott 2005a). Models attempting to explain the elk decline considered weather, hunting, and wolf predation, 
but they reached different conclusions (White et al. 2003, Vucetich et al. 2005, Varley and Boyce 2006).

Elk made up 90\% of northern range wolf kills during 1995-2000 (Smith et al. 2004). Potentially, wolves could reduce the elk population in YNP (Mech and Peterson 2003) because they are estimated to be taking about 7\% of adult female elk/year (Evans et al. 2006) and often prey disproportionately on young ungulates in their first months (Mech and Peterson 2003). However, little is known about wolf predation on elk neonates in YNP. Conceivably, wolves could kill enough elk calves each year that they substantially reduce the population. Alternatively, wolves could partially substitute (or compensate) for other forms of mortality such as winter malnutrition losses. Wolf predation might also compensate for deaths by other predators (e.g., grizzly bears [Ursus arctos], black bears [Ursus americanus], coyotes [Canis latrans], and cougars [Puma concolor]).

Although predisposition to mortality due to poor condition is important in the differentiation of compensatory and additive mortality, many cause-specific ungulate mortality studies do not screen for potential condition indicators (Linnell et al. 1995). Individual variation in condition may be exaggerated in neonates and juveniles due to their immature and weaker bodies (Schlegel 1976, Guinness et al. 1978, Singer et al. 1997, Smith and Anderson 1998). Several studies indicate that juvenile ungulates in poorer condition suffer greater predation (Seal et al. 1978, Kunkel and Mech 1994, Mech 2007, Carstensen et al. 2008). These factors may be associated with the true causal agent in predisposing juveniles to predation.

Disease is also an important ecological consideration in mortality studies. Moreover, it affects basic population parameters such as birth and death rates, age composition, and abundance (Eberhardt 1971, 1985). The importance of disease in the management of elk populations has been recognized for $>50$ years (Cowan 1951, Murie 1951, Honess and Winter 1956), and disease surveys are important to long-term monitoring of wild ungulate populations (Aguirre and Starkey 1994, Aguirre et al. 1995, Rhyan et al. 1997, Frolich 2000, Thorne et al. 2002). Early surveys on elk in YNP (Rush 1932, Tunnicliff and Marsh 1935, Worley and Barrett 1964, Greer 1968, Meagher 1974) did not have the capabilities to screen for the blood characteristics and diseases that are now considered routine. Although more recent surveys of blood characteristics and diseases have been conducted for adult elk in YNP (Aguirre et al. 1995, Rhyan et al. 1997, Barber-Meyer et al. 2007b), no studies surveyed neonatal elk. Several authorities have recommended such studies (Aguirre and Starkey 1994, Aguirre et al. 1995, National Research Council 2002), and recent research on white-tailed deer (Odocoileus virginianus) and elk neonates indicates that blood characteristics are useful in determining predisposition to mortality (Smith et al. 2006a, Carstensen et al. 2008).

Before wolf restoration, the annual survival rate for northern Yellowstone elk calves (1987-1990) averaged $0.43(\mathrm{SE}=0.18, n=$ 127; Singer et al. 1997). The greatest source of mortality among confirmed calf deaths was predation (43.9\%), mainly by bears and coyotes, followed by winter malnutrition (22.7\%). Summer survival of elk calves $(\bar{x}=0.65, \mathrm{SE}=0.13, n=127)$ was correlated with estimated birth mass. Winter survival $(\bar{x}=0.72, \mathrm{SE}=0.33, n$
$=82)$ increased with early calving and mildness of winter and was lowest (0.16) after the fires of 1988. During winter, starvation caused 15 of 26 deaths, whereas predation accounted for only one death (cougar). Some of this mortality seemed compensatory (Errington 1946) because predators killed more light-mass and late-born calves and calves were born lighter and later after severe winters (Singer et al. 1997). Overall, bear predation accounted for $22 \%$ of all calf mortality. The prewolf restoration data of Singer et al. (1997) provide a baseline for comparison with postwolf restoration data and assessment of the extent to which wolf predation on elk calves is compensatory or additive.

Large herbivore population dynamics may be largely driven by juvenile survival (recruitment) due to its inherent variability compared with adult survival (Allee et al. 1949, Pimlott 1967, Gaillard et al. 2000, Raithel 2005, Raithel et al. 2007). Inherent variability in elk calf survival in a Life Stage Simulation Analysis that used data from 37 sources (e.g., primarily Rocky Mountain and northwestern United States areas) accounted for $75 \%$ of the variation in population growth rates (Raithel et al. 2007). In hunted populations the annual change observed in population surveys is more likely influenced by elk calf survival than by adult female harvest (Raithel et al. 2007). Because elk calf survival greatly influences population trajectories, it is critical for wildlife managers to have reliable information before initiating predator management actions (e.g., reintroduction, restoration, and removal; Smith et al. 2006a). Calf recruitment is likely influenced most by habitat quality and elk density, predation, and adult male age structure (Gratson and Zager 1998).

Reduced habitat quality and higher elk densities influence elk calf recruitment by limiting the forage available to females, which can lead to diminished condition, decreased reproductive rates, and low-birth-mass calves (Thorne et al. 1976, Clutton-Brock et al. 1982, Singer et al. 1997, Cook 2000). Decreased juvenile survival has been correlated with lower birth mass in studies of elk, red deer, and other ungulates (Guinness et al. 1978, Nelson and Woolf 1987, Keech et al. 2000, Ditchkoff et al. 2001, Jenkins and Barten 2005), including northern Yellowstone elk calves during 1987-1990 (Singer et al. 1997). Poor habitat and higher adult female densities can also lead to reduced calf growth rates and reduced overwinter survival (Guinness et al. 1978; Cook et al. 1996, 2004).

Researchers that studied sympatric ungulate and wolf populations in Alaska, Canada, and Minnesota suggested that wolves can have substantial top-down control on ungulates (Ballard et al. 1987, 1991; Gasaway et al. 1992; Mech and Karns 1977; Messier 1994). High neonatal mortality due to predation has been observed in elk in the Greater Yellowstone Ecosystem (Smith and Anderson 1996, Singer et al. 1997) and elsewhere in Idaho (Schlegel 1976, Zager et al. 2005), Montana (Hamlin and Ross 2002, Raithel 2005, Harris 2007), and Washington, USA (Myers et al. 1996). Predation can be the primary factor limiting ungulate populations in areas where multiple predator species are sympatric (Gasaway et al. 1992, Kunkel and Pletshcer 1999).

A lack of mature males can lead to less synchronous breeding (Noyes et al. 1996). Birth synchrony in time and space is likely an optimal relationship between predator avoidance and forage quality (Carl and Robbins 1988, Linnell et al. 1995, Sinclair et 
al. 2000, Paquet and Brook 2004). Increased survival of peak-born neonates may be due to the dilution effect (i.e., the probability of each individual neonate being killed is diluted due to the abundance of other neonates; Darling 1938, Pulliam and Caraco 1984, Rutberg 1987), confusion effect (i.e., the ability of a predator to capture a particular neonate is reduced due to the presence and activities of other proximate neonates; Hamilton 1971), and increased defense afforded by numerous vigilant adult females (Kruuk 1964, Bergerud 1974, Estes 1976, Estes and Estes 1979, Wissel and Brandl 1988). Other studies on ungulate species reveal a high degree of synchrony likely due to seasonal forage availability (Sadlier 1969, Sekulic 1978) as it relates to nutritional condition.

Of the factors (i.e., habitat quality and elk density, predation, and male age structure), we predicted that predation and habitat quality were the most important influences on northern Yellowstone elk calf survival during 2003-2006. We did not expect male age structure to influence calf survival because there is no available evidence the synchrony of breeding has changed significantly (P. J. White, National Park Service, personal communication). We predicted predation would be more important than habitat quality to elk calf survival because of the multipredator system and the increase in predators since 1987-1990 (Singer et al. 1997). However, we considered habitat quality as secondarily important in potentially predisposing low-birth-mass neonates to mortality because of drought.

Yellowstone National Park last-winter (Feb-Mar) calf:adult female ratios dropped to approximately 13:100 during 2002-2004 compared with an average of 29:100 during 1990-2001 (White and Garrott 2005a). However, no information was available after wolf restoration regarding wolf predation on YNP elk calves $<5$ months of age when they were small and most vulnerable, although wolves selected older calves during winter (Smith et al. 2004). To determine the extent to which predators and other sources of mortality influence calf recruitment in the northern Yellowstone elk herd, we conducted a 3-year elk calf survival and mortality study during May 2003-April 2006. Our objective was to determine the basis for the decline in calf recruitment by estimating calf survival rates, estimating the relative causes and timing of calf deaths, and evaluating factors that may predispose calves to death.

\section{STUDY AREA}

Our study area consisted of the calving, summer, and winter ranges of the northern Yellowstone elk herd (Houston 1982, Cook et al. 2004). Yellowstone National Park (Fig. 1) encompasses $8,991 \mathrm{~km}^{2}$ of Wyoming, Montana, and Idaho in the western United States $\left(44^{\circ} \mathrm{N}, 110^{\circ} \mathrm{W}\right)$. Severe, sustained drought conditions existed during our study. The mean Palmer Drought Severity Index (Palmer 1965) for the growing season (May 1-July 31) across Division 1 of Wyoming (the upper northwestern corner) decreased from 0.9 during 1995 to -9.0 during 2005 compared with a mean of -1.0 during 1969-1995 (range $=-6.4$ to 2.9 ). The winters of 2001-2005 were relatively mild, with the accumulated daily value of snow water equivalent (Garrott et al. 2003) estimated at the Tower Falls weather station (WY9025) near Tower Junction, YNP, during 1 October to 30 April averaging $630 \mathrm{~cm}$ (range $=467-901 \mathrm{~cm})$ compared with a mean of $932 \mathrm{~cm}$ (range $=335-1,931 \mathrm{~cm})$ during the same period in 19692005.

During our study, counts of the northern Yellowstone elk herd averaged 9,032 (range =8,335-9,545; White and Garrott 2005a). These elk wintered and calved on the foothills and valley bottoms of the Gardiner, Yellowstone, and Lamar rivers in the northern portion of the park and adjacent areas of Montana (together referred to as the northern range, covering approximately 1,500 $\mathrm{km}^{2}$; Houston 1979, Lemke et al. 1998) in lower elevations $(1,550-2,500 \mathrm{~m})$ at a milder climate $(31.7 \mathrm{~cm}$ annual precipitation, $1.8^{\circ} \mathrm{C}$ mean temp) than the rest of YNP (Houston 1982). Typically, $30-35 \%$ of the annual precipitation at these lower elevations (relative to mountaintops on the northern range reaching 3,300 m) is snow (Farnes et al. 1999). Approximately $35 \%$ of the northern range is north of the park on Gallatin National Forest and privately owned lands (Lemke et al. 1998). One traditional calving area on the northern range, Stephens Creek/ Mammoth, contains a human residential area where elk congregate and predators are less likely to occur during spring and summer (K. Gunther and D. Smith, National Park Service, unpublished data). Other traditional calving areas in the northern range lack substantial residential areas that might serve as refuges for elk.

Big sagebrush (Artemsia tridentate), Idaho fescue (Festuca idahoensis), Douglas fir (Pseudotsuga menziesii), and quaking aspen (Populus tremuloides) were the primary shrubs and trees in our study area (Despain 1990). Extensive fires during 1998 caused partially by severe drought burned $36 \%$ of YNP (about $27 \%$ of the winter range used by northern Yellowstone elk burned), resulting in areas of burned and unburned forests at varying stages of succession (Despain et al. 1989, Singer et al. 1989).

Ungulates sympatric with northern Yellowstone elk on their winter range included approximately 700-1,000 bison (Bison bison), 2,000-2,500 mule deer (Odocoileus hemionus), 175-250 bighorn sheep (Ovis canadensis), 200-250 pronghorn (Antilocapra americana), $<200$ moose (Alces alces), $<100$ mountain goats (Oreamnos americanus), and $<25$ white-tailed deer (White and Garrott 2005b; P. J. White, unpublished data). Major sympatric predators included an unknown number of black bears (K. Gunther, unpublished data), approximately 70-92 grizzly bears (Haroldson and Frey 2005; K. Gunther, unpublished data), 20 cougars (Ruth 2004), 225 coyotes (Crabtree and Sheldon 1999), and 50-100 wolves (Smith 2005).

\section{METHODS}

\section{Capture and Handling}

We located elk calves $\leq 6$ days old, as indicated by their wet coats, wobbly stances, and attached umbilical cords (Johnson 1951), from air and ground (Barber et al. 2005). We (teams of $\geq 2$ people) attempted ground captures on calves observed opportunistically during 16 May-20 June 2003-2005 by hiking to areas where calves were seen by us from vehicles as we conducted daily ground telemetry (see Methods, Monitoring Radiotagged Calves) or areas where calves were reported by the public or YNP staff. We also conducted aerial searches using a Bell Jet Ranger helicopter during 2-3 days in early (19 May-25 May), middle (31 May-4 Jun), and late (6-10 Jun) portions of the calving season 


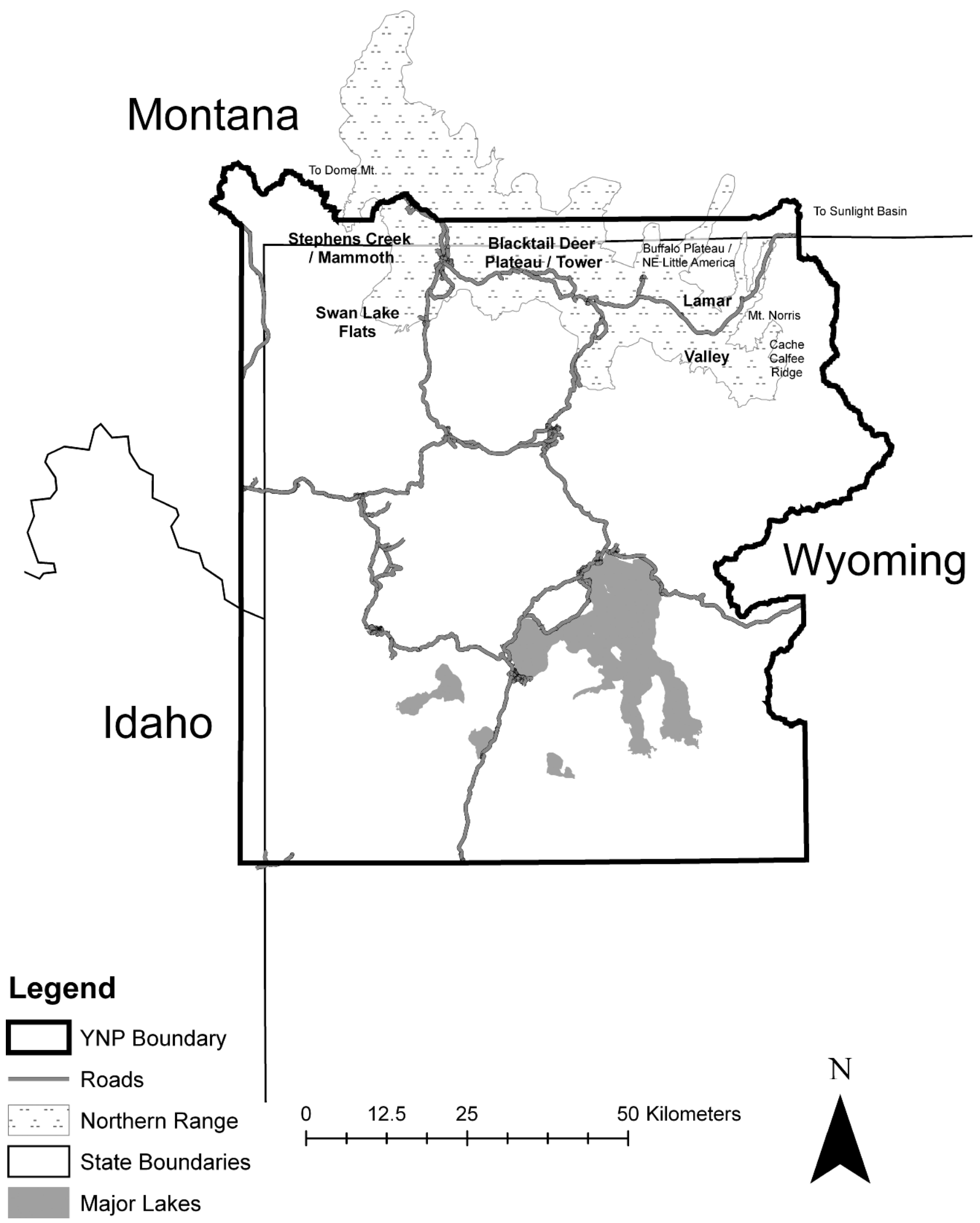

Figure 1. Yellowstone National Park (YNP), USA. Major elk calving areas on the northern range include Stephens Creek/Mammoth, Swan Lake Flats, Blacktail Deer Plateau/Tower, and Lamar Valley.

(i.e., 6-9 days/yr). The pilot flew transects over 4 traditional calving areas including the Stephens Creek/Mammoth (i.e., Sepulcher Mountain foothills), Swan Lake Flats, Blacktail Deer Plateau/Tower (including Mount Everts), and Lamar Valley (Fig.
1). We searched areas (during similar periods) where Singer et al. (1997) caught calves during the prewolf restoration study except for an area to the southeast of Lamar Valley (i.e., Cache Calfee Ridge), which Singer et al. (1997) were able to search using 
horses. We did not use horses to search for live calves due to logistical constraints. When a calf was spotted, the pilot landed in the vicinity and 2-3 biologists manually captured the calf. We captured and handled all elk in compliance with requirements of the Institutional Animal Care and Use Committee for the University of Minnesota (Protocol 0301A39581) and with the guidelines recommended by the American Society of Mammalogists (Gannon et al. 2007). We handled each calf for approximately 8 minutes.

We blindfolded and manually restrained captured calves. We used a fresh side of a ground cloth for each calf, and each person handling calves wore clean rubber gloves, to minimize the possibility of scent transfer to calves (although to our knowledge this has not been documented as an issue; Carstensen Powell et al. 2005). We aged calves using criteria determined by Johnson 1951 (e.g., dentition, navel healing, hair moisture on coat and in ears, ability to walk, and hoof and dewclaw wear). When a calf's characteristics equally overlapped 2 age categories, we coded its age as the mean. We sexed and weighed each calf to the nearest $0.23 \mathrm{~kg}$ using a hand-held spring scale and ground cloth that encompassed and supported the animal's entire body. In addition to the characteristics we used to age the calves, we also measured body-contour length, hind-foot length, eye-to-nose-tip length, and numbers of ticks in each ear (Johnson 1951, Haugen and Speake 1958).

We drew approximately $20-25 \mathrm{~mL}$ of blood by puncture of the jugular vein using 18 - or 20 -gauge $2.54-\mathrm{cm}$ or $3.81-\mathrm{cm}$ needles and a $35-\mathrm{mL}$ syringe. We placed blood in sterile, $10-\mathrm{mL}$ serumseparating tubes and centrifuged the blood within 4 hours of collection. We stored serum in $2-\mathrm{mL}$ or $5-\mathrm{mL}$ cryovials in a freezer $\left(-60^{\circ} \mathrm{C}\right)$ within $1-8$ hours. We shipped serum samples overnight on ice to various laboratories for analyses. The University of Minnesota's Veterinary Diagnostic Lab, St. Paul, Minnesota, USA, assayed thyroxine (T4) by chemiluminescence with the Immulite 1000 (Diagnostic Products Corporation, Los Angeles, $\mathrm{CA}$ ), and serum urea nitrogen (SUN) and $\gamma$-glutamyltransferase (GGT) were autoanalyzed with the Beckman CX7 (Beckman Coulter, Brea, CA; 2003 samples) and the Olympus AU400E (Olympus, Melville, NY; 2004 and 2005 samples). The University of Minnesota's Department of Veterinary and Biomedical Sciences laboratory (St. Paul, MN) assayed insulin-like growth factor-1 (IGF-1; human-based enzyme-linked immunosorbent assay [ELISA] kit; samples 2003-2004 catalog no. 026-AC-27F1, Alpco Diagnostics, Salem, NH; samples 2005 catalog no. AC27F1, Immuno Diagnostics Systems, Incorporated, Fountain Hills, AZ). The Minnesota Department of Natural Resources' laboratory, Grand Rapids, Minnesota, assayed gamma globulins (GG) by absorption spectroscopy with the Stasar III spectrophotometer (Gilford Systems, Ciba Corning Diagnostics Corporation, Oberlin, OH). The University of Minnesota's Veterinary Diagnostic Lab assayed all diseases. The lab tested sera for prevalence of antibodies against bovine-viral-diarrhea virus type 1 (BVD-1, serum neutralization test $[\mathrm{SN}]$ ), infectious-bovine rhinotracheitis virus (IBR, SN), parainfluenza-3 virus (PI-3, hemagglutination inhibition), bovine-respiratory syncytial virus (BRSV, SN), and Brucella abortus. All evaluations were bovine-based except for $B$. abortus tests, which were elk-validated. None of the tests detected actual disease-causing agents; thus, they were not considered gold standard tests (Thrusfield 2005). Brucellosis results were summarized as positive or negative using card tests during 2003-2005 and complement fixation tests during 2003-2004. We interpreted disease titers as follows: $>1: 16$, exposed to the disease; $=1: 16$, possibly exposed; and $<1: 16$, not exposed (except for PI-3 because these titers were not reported in 1:4 dilutions; therefore, these titers were interpreted as follows: $>1: 20$, exposed; $=1: 20$, possibly exposed; and <1:20, not exposed). We used these conservative titer level categories to avoid false positives (Goyal et al. 1988). We constructed $95 \%$ confidence intervals for seroprevalence following Thrusfield (2005). We reported the interleukin-6 (IL)-6 and tumor necrosis factor (TNF)- $\alpha$ values for these calves separately (Barber-Meyer et al. 2007a).

We fit each calf with an ear-tag transmitter (model 3430, Advanced Telemetry Systems, Inc., Isanti, MN) weighing approximately $23 \mathrm{~g}$ and designed to emit a radiosignal each day for 12 hours for approximately 1 year. Each transmitter changed pulse rate if it remained motionless for $>4$ hours. This change in pulse rate (i.e., mortality mode/signal) alerted us that the animal was likely dead and enabled us to examine the carcass soon after death (O'Gara 1978, Garner et al. 1985, Larsen et al. 1989, Adams et al. 1995). Thus, the transmitters allowed us to quickly and conveniently monitor daily survival without visually locating each animal.

\section{Monitoring Radiotagged Calves}

During May through mid-July, when the risk of mortality to calves was relatively high, we monitored transmitter frequencies of ear-tagged calves via airplane (Montana Aircraft, Belgrade, MT) each day at dawn to determine calf survival. As calves became older and less prone to predation because they were able to escape predators by running (Altmann 1952, Geist 2002), we reduced aerial monitoring to $3 \times /$ week during mid- to late July, $2 \times /$ week during August-21 September, and bimonthly thereafter (except during Sep 2005-May 2006 when we monitored calf signals aerially approx. $1 \times / 10$ days). The pilot obtained Universal Transverse Mercator coordinate locations for all dead calves using a Global Positioning System unit and searched for predators in the vicinity of the carcass. This approach reduced the risk of ground crews displacing predators from carcasses that could result in artificially high calf mortality if displaced predators killed additional calves to compensate for the food lost by being displaced. However, any displacement likely had a trivial effect on the amount of carcass consumed because elk calves were relatively small and quickly consumed, with little of the carcass remaining by the time ground crews arrived. Ground crews also monitored transmitter frequencies of ear-tagged calves 3-4X/day until midJuly and less frequently (approx. $4 \times /$ week) during mid-July to the following July, except during 2005 when ground tracking ended in late August 2005.

\section{Investigating Mortality Sites}

Ground crews investigated mortality sites and conducted necropsies of dead calves to evaluate causes of death based on evidence such as predator tracks, consumption patterns, canine puncture measurements, and scat measurements (O'Gara 1978, Roy and Dorrance 1976, Wade and Bowns 1985). Crews also collected hair samples for predator identification (Moore et al. 1974) at the 
University of Idaho's Laboratory for Ecological and Conservation Genetics (Moscow, ID, USA). Although we attempted to collect a long bone midsection and metatarsus from each calf for condition analyses (Cheatum 1949), the bones were generally broken or missing; therefore, we did not have a sufficient sample for analyses.

We coded calf fates through the first year of life as survivor, mortality, or censored. We evaluated mortality events following methods modified from those used by Garner et al. (1985) and Kunkel and Mech (1994). We concluded that a carcass was scavenged if we determined no 1) evidence of subcutaneous hemorrhaging; 2) aspirated blood in mouth, nose, or trachea; or 3) signs of struggle including scuff or track evidence of chase and struggle, blood on the ground from pursuit, broken branches, or blood on plants. Censored events included missing radiosignals, inability to examine 2 possible mortality sites due to wildfires in 2003 and high water in 2005, and possible transmitter pull-outs (i.e., only an intact transmitter was located, and no remains of a calf carcass, evidence of an attack, or predator evidence was found).

\section{Statistical Analyses}

We used chi-square tests to evaluate sex-ratio differences. We estimated calf birth mass from capture mass using sex-specific linear regression of estimated age of all calves $\geq 1$ day old versus capture mass (Smith et al. 1997). We assumed capture mass of calves $<1$ day old to be their birth mass. We used 3-way analysis of variance (ANOVA) to examine variation of mean calf-capture ages, estimated birth masses, and estimated birth dates by sex, calving area, and capture year. We used 2-way ANOVA to test for main effects and 2-way interactions of capture year, calving area, sex, and age at capture ( $\leq 1.5$ days, $2-4.5$ days, and $\geq 5$ days) collectively with each categorical seroprevalence of disease (i.e., BVD-1, IBR, and PI-3) and continuous blood characteristic (i.e., T4, SUN, IGF-1, GGT, and GG) as dependent variables. We did not include possibly exposed disease cases (i.e., titers of 1:16 for diseases other than PI-3 and brucellosis and titers of 1:20 for PI3 ) in ANOVA due to the small number of cases. Also, we could not test for higher-order ( $>2$-way) interactions due to limited samples. We did not adjust the $\alpha$ level of significance for multiple comparisons because we were more concerned with potentially overlooking an important predictor of condition than falsely identifying a potential predictor. We used linear regression to assess the impact of disease seroprevalences and continuous blood characteristics on mean estimated birth mass after accounting for main effects and interactions among capture year, calving area, and sex. We transformed continuous blood characteristics for ANOVAs and regressions to logarithm base 10 to help stabilize variance and lessen the impact of extreme cases (Krebs 1999). We back-transformed from logarithms the means and confidence intervals of continuous blood characteristics from ANOVAs and regressions. We did not back-transform standard errors from logarithms because they have no meaning once back-transformed (Krebs 1999). We conducted all regression analyses with Arc version 1.06 (Cook and Weisberg 1999) and eliminated cases that caused nonconstant variance and curvature in the residual function (assessed through model-checking plots), statistical outliers (outlier $t$ statistic), and cases with Cook's Distance values $>0.2$
(Cook and Weisberg 1999). We used 2-way ANOVA to examine variation of the probability of being killed by a bear or all predators combined by capture year, calving area, sex, and birth period. For each year, we divided the number of days from the earliest estimated birth date to the latest estimated birth date into 3 equal ( \pm 1 day) birth-period categories (i.e., prepeak, peak, and postpeak) and classified each calf's birth accordingly. We used 1-way ANOVA to assess variation of mean monthly spring precipitation (cm; Mar-May) during years. We conducted ANOVAs and all other statistical procedures with STATISTICA version 6 (StatSoft, Tulsa, OK). We considered all differences significant at $\alpha=0.05$.

\section{Survival Analyses}

We used known-fate models (White and Garrott 1990, Bunck and Pollock 1993) in Program MARK (version 4.1, Jul 2004; White and Burnham 1999, Cooch and White 2002) to estimate summer (20 weeks post-radiotagging; approx. late May-early Jun through early to late Oct), winter (Nov-Apr), and annual (MayApr) survival of elk calves and model covariate influences on summer survival. We used periods of 1 week to model summer survival and 1 month to model winter and annual survival. Using information from our data, we created temporal survival models for summer, winter, and annual survival (Chouinard and Arnold 2007). Then, we used forward selection to evaluate other influences on survival. We lost radiosignals from 2 tagged calves within the first week after radiotagging, and we did not include these calves in our survival analyses.

For summer survival, we did not use the staggered entry design (Pollock et al. 1989) because we captured all calves within approximately 3 weeks, and mortality was highly concentrated in the first 2 weeks after capture (Pojar and Bowden 2004). For summer calf encounter histories $(n=116)$, we used 1 -week intervals to record radiotagging, survival, mortality, and censor events. We left-justified calf histories, so survival estimates related to calf survival by weeks irrespective of the actual date calves were radiotagged (Vreeland et al. 2004, Raithel 2005).

We first modeled constant summer survival through 20 weeks. We then modeled summer survival as different for each week through 20 weeks, and we graphed the results to identify similar periods of survival (Chouinard and Arnold 2007). We used this information and supporting biological information (Geist 2002, Irwin 2002) to model survival as life-stage specific including 3 periods: 1-2 weeks when calves were hiders or inexperienced runners (Lent 1974), 3-6 weeks when calves were better runners and joined nursery herds (Altmann 1952), and 7-20 weeks when calves were able to migrate with the herd to higher-elevation summer ranges. We selected the 3-phase (1-2, 3-6, and 7-20 weeks) life-stage-specific model from among the other models (i.e., constant survival and different survival for each week) using Akaike's Information Criterion (AIC) adjusted for small samples (lowest $\mathrm{AIC}_{i}$; Hurvich and Tsai 1995), provided there were no other candidate models within $\Delta \mathrm{AIC}_{c}<2$.

We tested for capture-year and capture-area effects using the triphasic life-stage-specific model. We modeled 4 scenarios: 1) life-stage-specific survival with an interactive capture-year effect through week 6 ; 2) life-stage-specific survival with an additive capture-year effect through week 6;3) life-stage-specific survival 
with an interactive capture-area effect through week 6; and 4) lifestage-specific survival with an additive capture-area effect through week 6 . Among these 4 models and the life-stage-specific model without capture-year or capture-area effects, we selected the model with the lowest $\mathrm{AIC}_{c}$ provided there were no other candidate models within $\Delta \mathrm{AIC}_{c}<2$.

We used this base model to evaluate the importance of individual covariates on summer survival, including estimated birth date (bdt), absolute deviation in days from median birth date (bdtdev), estimated birth mass (bms), sex, and estimated capture age (age; Johnson 1951), which have been documented as important to neonatal ungulate survival (Thorne et al. 1976, Clutton-Brock et al. 1982, Smith and Anderson 1996, Singer et al. 1997, Raithel 2005). Our sample size precluded us from evaluating the importance of body-contour length or hind-foot length on survival, and these variables were significantly correlated with bms ( $r=0.54$ and $r=0.32$, respectively; both $P<0.01$ ). We also evaluated the importance of potential condition indicators, including T4, SUN, IL-6, GG, IGF-1, GGT, TNF- $\alpha$; PI-3, IBR, and BVD-1, which could affect survival but have seldom been studied in neonate ungulates (Linnell et al. 1995). To test for outliers and influential cases among continuous covariates (except IL-6; see below in this paragraph), we standardized their values to a mean of zero and noted cases that had standard deviations $>4$. We created models with and without these cases to assess their influence on a model. If a covariate was in a model that was not a candidate model with or without these cases, then we included cases for that covariate to increase the overall sample. Because the distribution of IL-6 contained 37\% zeros (51/138) and showed positive skew (Barber-Meyer et al. 2007a), we added 0.5 to the IL-6 values and transformed this number to logarithm base 10 to lessen the impact of extreme values (Krebs 1999).

We assessed the additive importance of these covariates on summer survival during weeks 1-6 (because very little mortality occurred after these weeks) with forward selection by adding them each singly to the base model (Cook and Weisberg 1999). We selected the model with the lowest $\mathrm{AIC}_{c}$ from among these models and the base model without covariates. To this new base model containing one covariate, we added singly any other covariates whose addition in the last step resulted in a lower $\mathrm{AIC}_{c}$ than the previous base model without any covariates. We selected the model with the lowest $\mathrm{AIC}_{c}$ that had 2 covariates if it had a lower $\mathrm{AIC}_{c}$ than the previously selected model with one covariate. Using this new base model, we added singly any other covariates whose addition resulted in a lower $\mathrm{AIC}_{c}$ than the model that had one covariate. We continued this process until the addition of covariates did not result in a lower $\mathrm{AIC}_{c}$ than the current base model. We selected the model with the lowest $\mathrm{AIC}_{c}$ that contained only covariates whose $95 \%$ confidence intervals of the $\beta$ estimates did not contain zero. In all of our survival models (i.e., summer, winter, and annual) the addition of a variable whose confidence interval contained zero always caused $\geq 1$ other variable's confidence interval to then contain zero, which indicated near collinearity (Cook and Weisberg 1999). Thus, the most recently added variable contained little new information about the response (i.e., little predictive power). Our approach that tested each covariate independently allowed the variable with the greatest explanatory power to enter and remain in the model first, and so on with successive variables. We then tested for nonlinear effects among continuous covariates in this model by adding singly the quadratic form of each continuous covariate (i.e., covariate ${ }^{2}$ ). If the quadratic form resulted in a lower $\mathrm{AIC}_{c}$, we retained the quadratic term. Otherwise, we selected the model with the lowest $\mathrm{AIC}_{c}$ with covariates whose $\beta$ estimates did not have $95 \%$ confidence intervals including zero (Neter et al. 1996). During final model selection, we evaluated candidate models within $\Delta \mathrm{AIC}_{c}<2$ based on their $\mathrm{AIC}_{c}$ weight and parameter differences from the model with the lowest $\mathrm{AIC}_{c}$ that did not contain any covariates whose $\beta$-estimate confidence intervals contained zero.

Using logit equations containing $\beta$ estimates from the selected summer-survival candidate models, we evaluated the influence of each covariate across the range of observed values for that covariate on survival (holding all other covariates in the model at mean levels) in each calving area (i.e., Stephens Creek/Mammoth, Swan Lake Flats, Blacktail Deer Plateau/Tower, and Lamar Valley) for each model using Microsoft Office Excel 2003 (Microsoft, Redmond, WA).

For winter (Nov-Apr) and annual (May-Apr) survival, we followed a similar approach, but we did not assess the importance of individual covariates because the majority of mortality occurred during summer and ignoring covariates allowed the inclusion of more cases. We started all calf histories on 1 November for the winter survival analyses. Because we were more interested in monthly patterns than actual calf age (which we assessed in summer survival), we staggered our entries for annual survival analyses, entering some calves during May and some during June. We first modeled constant survival during each month (i.e., NovApr for winter, May-Apr for annual). We then modeled survival as different for each month, and we graphed the results to identify similar periods of survival (Chouinard and Arnold 2007). Next, using this information, we modeled survival grouped by months of similar survival. We selected this model containing months grouped by similar survival from among the other models (i.e., constant survival and different survival for each month) using $\mathrm{AIC}_{c}$ (lowest $\mathrm{AIC}_{c}$; Hurvich and Tsai 1995), provided there were no other candidate models within $\Delta \mathrm{AIC}_{c}<2$.

We tested for capture-year and capture-area effects using the model grouped by months of similar survival as our base model. We modeled 4 scenarios for winter survival: 1) the base model with an interactive-year effect, 2) the base model with an additiveyear effect, 3) the base model with an interactive capture-area effect, and 4) the base model with an additive capture-area effect. We selected the model with the lowest $\mathrm{AIC}_{c}$ from these 4 models and the base model without capture-year or capture-area effects. For annual survival, we modeled the above-mentioned 4 scenarios and an additional scenario, the base model with an additive capture-area effect during only May-June, and we selected from among these models and the base model without capture-year or capture-area effects using $\mathrm{AIC}_{c}$. During final model selection, we evaluated candidate models within $\Delta \mathrm{AIC}_{c}<2$, if present, based on their $\mathrm{AIC}_{c}$ weight and parameter differences from the model with the lowest $\mathrm{AIC}_{c}$.

Because no goodness-of-fit statistic is available for known-fate models, we investigated model robustness by artificially inflating $\hat{c}$ 
(i.e, a model term representing dispersion) from 1.0 to 3.0 (i.e., no dispersion to extreme dispersion) to simulate various levels of dispersion (Devries et al. 2003) reflected in quasi-AIC ${ }_{c}\left(\mathrm{QAIC}_{c}\right)$ values.

\section{RESULTS}

\section{Capture and Birth Characteristics}

We captured 83 female and 68 male $(n=151)$ neonate elk throughout calving areas (i.e., Stephens Creek/Mammoth, Swan Lake Flats, Blacktail Deer Plateau/Tower, and Lamar Valley) across the northern range of YNP (Fig. 1) and throughout the calving season. We captured similar numbers of calves each year (Table 1). We also captured similar numbers of calves in each of the 4 main calving areas and during each of the main calving periods that we categorized based on calving observations as follows: early (19-25 May); peak (26 May-2 Jun); and late (3 Jun10 June; Table 1$)$.

None of the within-year or across-year sex ratios were significantly different from parity $\left(2003 \chi_{\text {obs }}^{2}=3.31, P=0.07\right.$; $2004 \chi_{\text {obs }}^{2}=0.09, P=0.76 ; 2005 \chi_{\text {obs }}^{2}=0.00, P=1.00$; and $\left.2003-2005 \chi_{\text {obs }}^{2}=1.49, P=0.22 ; \mathrm{df}=1\right)$, and none of the sex ratios was significantly different from one another (2003 and 2004 $\chi_{\text {obs }}^{2}=1.06, P=0.30 ; 2003$ and $2005 \chi_{\text {obs }}^{2}=1.76, P=0.18$; and 2004 and $2005 \chi_{\text {obs }}^{2}=0.05, P=0.82$; df $\left.=1\right)$. The pooled 20032005 sex ratio was significantly different $\left(\chi_{\text {obs }}^{2}=4.28, P=0.04\right.$, df $=1$ ) from the pooled 1987-1990 sex ratio (73M:54F; Singer et al. 1997), with more females captured during 2003-2005.

Estimated birth mass $(\bar{x}=14.91 \mathrm{~kg}, \mathrm{SE}=0.21, n=148)$ differed by sex $\left(P<0.01, F_{1,124}=31.15\right)$ and capture year $(P<0.01$, $\left.F_{2,124}=8.88\right)$. Males $(\bar{x}=16.04 \mathrm{~kg}, \mathrm{SE}=0.31, n=68)$ weighed significantly more than females $(13.96 \mathrm{~kg}, \mathrm{SE}=2.24, n=80)$. Although mean estimated pooled sex birth mass was similar during $2003(\bar{x}=14.31 \mathrm{~kg}, \mathrm{SE}=0.29, n=48)$ and $2004(\bar{x}=14.26$ $\mathrm{kg}, \mathrm{SE}=0.39, n=44)$, it was significantly higher during $2005(\bar{x}=$ $15.94 \mathrm{~kg}, \mathrm{SE}=0.37, n=56$ ). Estimated birth masses did not vary by any 2 -way interactions of sex, capture year, capture age, or capture area. We could not evaluate 3- and 4-way interactions due to small samples.

Males $\geq 1$ day old were born heavier than females, but females had a higher growth rate through day 6 (male capture mass $=$ $15.71 \mathrm{~kg}+0.85 \times$ estimated capture age in days; $n=56, r^{2}=0.18$, $F_{1,54}=11.89, P<0.01$; female capture mass $=13.67 \mathrm{~kg}+1.34 \times$ estimated capture age in days; $n=63, r^{2}=0.36, F_{1,61}=34.88, P<$ 0.01 . To meet regression assumptions of constant variance and no curvature among residuals, we had to censor 2 male cases (both age 5 days) and 3 female cases (age 5.5, 6, and 6 days). After these cases were censored, there were no problems with curvature among residuals, nonconstant variance, or outliers.

Estimated ages of elk calves at capture ranged from 0.5 days to 6.0 days, with an average of 2.5 days $(0.12 \mathrm{SE}, n=151)$. Estimated age at capture did not vary significantly by capture year, calving area, sex, or any interactions of these variables.

Estimated birth dates ranged from 16 May to 10 June $(\bar{x}=28$ May, $\mathrm{SE}=0.55, n=151)$. Although estimated birth dates varied by capture year $\left(P=0.05, F_{2,127}=3.10\right)$, their means were similar, with the latest during 2003 ( 29 May, $\mathrm{SE}=1.06, n=51$ ), the earliest during 2005 (27 May, $\mathrm{SE}=0.81, n=56$ ), and the mean
Table 1. Background information about neonatal elk studied during 2003-2005 on the northern range of Yellowstone National Park, USA.

\begin{tabular}{lrrrr}
\hline \multicolumn{1}{c}{ Neonatal elk information } & $\mathbf{2 0 0 3}$ & $\mathbf{2 0 0 4}$ & $\mathbf{2 0 0 5}$ & Total \\
\hline Captures & & & & \\
$\quad$ Total & 51 & 44 & 56 & 151 \\
$\quad$ Ground captures & 6 & 4 & 1 & 11 \\
$\quad$ Aerial captures & 45 & 40 & 55 & 140 \\
Calving periods & & & & \\
$\quad$ Early (19-25 May) & 14 & 11 & 26 & 51 \\
$\quad$ Peak (26 May-2 Jun) & 17 & 20 & 18 & 55 \\
Late (3-10 Jun) & 20 & 13 & 12 & 45 \\
Capture areas & & & & \\
$\quad$ Stephens Creek/Mammoth & 14 & 12 & 13 & 39 \\
Swan Lake Flats & 11 & 14 & 14 & 39 \\
Blacktail Deer Plateau/Tower & 9 & 10 & 11 & 30 \\
$\quad$ Lamar Valley & \\
Sex & 17 & 8 & 18 & 43 \\
M & & & & \\
F & 19 & 21 & 28 & 68 \\
\hline
\end{tabular}

${ }^{a}$ Included one capture in the Buffalo Plateau/Northeast Little America area.

during 2004 (28 May, $\mathrm{SE}=0.99, n=44)$. Estimated birth dates did not vary significantly by calving area, sex, or any 2- or 3-way interactions of calving area, sex, and capture year. We categorized birth periods as 18-25 May (prepeak), 26 May-2 June (peak), and 3-10 June (postpeak) during 2003; 16-23 May (prepeak), 24-31 May (peak), and 1-8 June (postpeak) during 2004; and 19-24 May (prepeak), 25 May-1 June (peak), and 2-7 June (postpeak) during 2005.

\section{Blood Characteristics and Disease Seroprevalence}

Blood concentrations of IGF-1, GGT, GG, and SUN varied by capture year $\left(P \leq 0.01\right.$; IGF- $1 F_{2,101}=17.74$, GGT $F_{2,103}=6.54$, GG $F_{2,84}=7.26$, and SUN $F_{2,84}=4.52$; Table 2). Calves captured during 2005 averaged the highest IGF- 1 concentrations $(\bar{x}=324$ $\mathrm{ng} / \mathrm{mL}, \mathrm{SE}=0.02, n=50)$ and the lowest GGT $(\bar{x}=47 \mathrm{IU} / \mathrm{L}, \mathrm{SE}$ $=0.03, n=48)$ and $\mathrm{GG}$ concentrations $(\bar{x}=0.95 \mathrm{~g} / \mathrm{dL}, \mathrm{SE}=0.03$, $n=42)$. Calves captured during 2003 had the lowest SUN concentrations $(\bar{x}=15 \mathrm{mg} / \mathrm{dL}, \mathrm{SE}=0.03, n=40)$. Serum urea nitrogen varied by capture area $\left(P=0.02, F_{3,99}=3.53\right)$, with calves captured in Swan Lake having the lowest SUN concentrations ( $\bar{x}$ $=15 \mathrm{mg} / \mathrm{dL}, \mathrm{SE}=0.03, n=35)$. Thyroxine, SUN, and GG all varied by capture age $\left(P<0.01\right.$; T4 $F_{2,99}=35.99$, SUN $F_{2,99}=$ 16.83 , and $\left.\mathrm{GG} F_{2,84}=15.60\right)$. Calves $\leq 1.5$ days old averaged the highest $\mathrm{T} 4(\bar{x}=18 \mu \mathrm{g} / \mathrm{dL}, \mathrm{SE}=0.02, n=43)$ and SUN concentrations $(\bar{x}=21 \mathrm{mg} / \mathrm{dL}, \mathrm{SE}=1.3, n=43)$ and the lowest GG concentrations $(\bar{x}=0.83 \mathrm{~g} / \mathrm{dL}, \mathrm{SE}=0.07, n=32)$. Only GG varied with capture age by sex $\left(P=0.04, F_{2,84}=3.31\right)$, with females $\leq 1.5$ day old having the lowest concentrations $(\bar{x}=0.75$ $\mathrm{g} / \mathrm{dL}, \mathrm{SE}=0.10, n=19)$ and males $\geq 5$ days old having the highest concentrations ( $\bar{x}=1.9, \mathrm{SE}=0.05, n=5)$. No other 2-way interactions were significant, and no continuous blood characteristics were significant predictors of estimated calf birth mass after accounting for sex, capture year, and calving area.

We detected high seroprevalences of IBR (58\%) and PI-3 (32\%), but low seroprevalences of BRSV (3\%) and brucellosis (3\%; Table 3). Only BVD-1 varied with capture year as a main effect $(P=$ $\left.0.05, F_{2,98}=3.13\right)$, having the highest seroprevalence during 2004 
Table 2. Values of blood characteristics of neonatal elk in the northern range of Yellowstone National Park, USA, 2003-2005.

\begin{tabular}{|c|c|c|c|c|c|}
\hline Blood characteristic (units) & $\bar{x}$ & SE & $n$ & Min. & Max. \\
\hline Thyroxine $(\mu \mathrm{g} / \mathrm{dL})^{\mathrm{a}}$ & 14 & 0.43 & 131 & 6.7 & 24 \\
\hline Serum urea nitrogen $(\mathrm{mg} / \mathrm{dL})^{\mathrm{b}}$ & 17 & 0.57 & 131 & 2.0 & 39 \\
\hline$\gamma$-Glutamyltransferase $(\mathrm{IU} / \mathrm{L})^{\mathrm{c}}$ & 63 & 2.7 & 134 & 19 & 184 \\
\hline Insulin-like growth factor-1 $(\mathrm{ng} / \mathrm{mL})^{\mathrm{d}}$ & 261 & 9.2 & 133 & 78 & 764 \\
\hline Gamma globulins $(\mathrm{g} / \mathrm{dL})^{\mathrm{e}}$ & 1.6 & 0.07 & 120 & 0.10 & 3.3 \\
\hline
\end{tabular}

${ }^{\mathrm{a}}$ We censored 1 case $(3.6 \mu \mathrm{g} / \mathrm{dL})$.

${ }^{\mathrm{b}}$ We censored 1 case $(2.0 \mathrm{mg} / \mathrm{dL})$.

${ }^{\mathrm{c}}$ We censored 1 case $(524 \mathrm{IU} / \mathrm{L})$.

${ }^{\mathrm{d}}$ We censored 4 cases $(5.4,18,21$, and $43 \mathrm{ng} / \mathrm{mL})$.

${ }^{\mathrm{e}}$ We censored 8 cases (one 0.20 , three 0.10 , and four $0.00 \mathrm{~g} / \mathrm{dL}$ ).

$(\bar{x}=0.38, \mathrm{SE}=0.08, n=42)$. Bovine-viral-diarrhea virus type 1 also varied by 2 interactions, capture year by calving area $(P=0.05$, $\left.F_{2,98}=2.20\right)$ and calving area by sex $\left(P=0.04, F_{2,98}=2.98\right)$. Bovine-viral-diarrhea virus type 1 was not detected in the Blacktail Deer Plateau calving area during $2003(n=8)$ or the Lamar Valley calving area during $2005(n=16)$. The highest BVD-1 seroprevalence of year by area interactions was recorded during 2005 in the Blacktail Deer Plateau calving area $(\bar{x}=0.55$, $\mathrm{SE}=0.16, n=11)$. Bovine-viral-diarrhea virus type 1 seroprevalence was lowest among area by sex interactions in females captured in Lamar Valley $(\bar{x}=0.06, \mathrm{SE}=0.06, n=18)$ and highest in males captured in Swan Lake Flats $(\bar{x}=0.50, \mathrm{SE}=$ $0.14, n=14)$. Infectious-bovine rhinotracheitis $(n=119)$ varied by capture age $\left(P<0.01, F_{1,88}=17.76\right)$, sex $\left(P=0.05, F_{1,88}=3.89\right)$, and capture year by sex $\left(P=0.02, F_{2,88}=4.24\right)$. Calves $\leq 1.5$ days old had lower mean IBR seroprevalence $(\bar{x}=0.35, \mathrm{SE}=0.08, n=$ 37) than calves aged $2-4.5$ days $(\bar{x}=0.79, \mathrm{SE}=0.05, n=72)$ and $\geq 5$ days $(\bar{x}=0.70, \mathrm{SE}=0.15, n=10)$. Males had higher mean seroprevalence $(\bar{x}=0.76, \mathrm{SE}=0.06, n=54)$ than females $(\bar{x}=$ $0.55, \mathrm{SE}=0.06, n=65)$. Males born during 2004 had the highest seroprevalence $(\bar{x}=1.0, \mathrm{SE}=0.0, n=19)$, whereas females born during 2003 had lower mean seroprevalence $(\bar{x}=0.48, \mathrm{SE}=0.11$, $n=21$ ). Exposure to disease (i.e., BVD-1, PI-3, and IBR) was not a significant predictor of estimated calf birth mass after accounting for capture year, calving area, and sex. The lack of significant variation in BRSV and brucellosis seroprevalences precluded testing with ANOVAs or regressions.

\section{Survival}

The summer survival model with the lowest $\mathrm{AIC}_{c}$, after excluding models with $\beta$-estimate $95 \%$ confidence intervals containing zero, was the life-stage-specific model with an additive capture-area effect (area) through week 6 and the additive covariate bdtdev through week 6, S(1-2,3-6,7-20wk+area_6wk+bdtdev_6wk). Another candidate model was similar but differed by the inclusion of GG through week 6 rather than bdtdev. The only other candidate models within $\Delta \mathrm{AIC}_{c}<2$ differed by the inclusion of the quadratic form of the covariates (Table 4). Because the quadratic terms did not result in lower $\mathrm{AIC}_{c} \mathrm{~s}$, we did not retain these terms. Therefore, we selected models 9 and 10 (Table 4). Models 9 and 10 (Table 4) had the lowest $\mathrm{QAIC}_{c}$ when $\hat{c}=2.0$ (moderate dispersion) and both were candidate models $\left(\Delta \mathrm{QAIC}_{c} \leq 0.636\right)$ through $\hat{c}=3.0$ (extreme dispersion). Sample limitations precluded us from examining the relationships between survival and long bone midsection marrow-fat content, metatarsus length, body-contour length, hind-foot length, and eye-to-nose-tip length. Because we detected no ticks in the ears of captured calves, we also did not evaluate tick load relative to calf survival.

We used the equations (Table 5) generated from the knownfates model in Program MARK to estimate life-stage- and areaspecific survival estimates through 20 weeks post-radiotagging with standardized covariates (i.e., [variable value - variable mean]/ variable $\mathrm{SD})$. We then estimated summer survival of elk born in various calving areas as $\left(e^{\text {Logit }}\right) /\left(1+e^{\text {Logit }}\right)$ for each period for each model (Cooch and White 2002). To calculate summer survival for elk calves born in various calving areas, we squared the estimate for survival in each calving area/week during weeks 1-2 (2 weeks) and multiplied by the estimate for survival in each area/week during weeks 3-6 (4 weeks) to the fourth power and multiplied by the estimate for survival pooled across all areas/week during weeks 720 (14 weeks) to the 14th power. We generated the estimate for survival during weeks 7-20 in Program MARK. Using the selected model containing bdtdev, calf survival to 20 weeks after radiotagging was $0.29(\mathrm{SE}=0.05, n=116)$, and survival pooled across capture areas and years was $0.65(\mathrm{SE}=0.04)$ during weeks $1-2,0.94(\mathrm{SE}=0.02)$ during weeks $3-6$, and $0.99(\mathrm{SE}<0.01)$ during weeks 7-20. Using the selected model containing GG, calf survival to 20 weeks after radiotagging was $0.30(\mathrm{SE}=0.05, n=$ 116), and survival pooled across capture areas and years was 0.66 $(\mathrm{SE}=0.04)$ during weeks 1-2, $0.94(\mathrm{SE}=0.02)$ during weeks 3-6, and 0.99 (SE < 0.01) during weeks 7-20. These estimates of summer survival from each model through 20 weeks were similar to the finite survival rate observed during the same period (0.29$0.34, n=151$, depending on whether censored animals were considered alive or dead). Estimated summer survival was $>5 \times$ higher for calves captured in the Stephens Creek/Mammoth area (0.60 for bdtdev model and 0.57 for GG model, $n=29$ ) than for

Table 3. Seroprevalence (prevalence; 95\% confidence interval $[n / N]$ ) of disease antibodies in neonatal elk (2003-2005) and adult female elk ${ }^{\mathrm{a}}(2000-2005)$ on the northern range of Yellowstone National Park, USA.

\begin{tabular}{|c|c|c|c|c|}
\hline \multirow[b]{2}{*}{ Disease } & \multicolumn{2}{|c|}{ Neonatal elk } & \multicolumn{2}{|c|}{ Ad F elk } \\
\hline & Positive & Possibly positive & Positive & Possibly positive \\
\hline Bovine-viral-diarrhea virus type 1 & $25 ; 18-32(33 / 132)$ & $2 ; 0-4(2 / 132)$ & $24 ; 16-32(26 / 109)$ & $11 ; 5-17(12 / 109)$ \\
\hline Infectious-bovine rhinotracheitis & $58 ; 50-66(77 / 133)$ & $11 ; 5-16(14 / 133)$ & $4 ; 0-8(3 / 81)$ & $12 ; 5-20(10 / 81)$ \\
\hline Bovine parainfluenza-3 & $32 ; 24-40(42 / 131)$ & $15 ; 9-21(19 / 131)$ & $70 ; 61-79(74 / 106)$ & $12 ; 6-19(13 / 106)$ \\
\hline Bovine-respiratory syncytial virus & $3 ; 0-6(4 / 130)$ & $5 ; 2-9(7 / 130)$ & $0(0 / 81)$ & $1 ; 0-4(1 / 81)$ \\
\hline Brucellosis & $3 ; 0-6(4 / 130)$ & $1 ; 0-2(1 / 130)$ & $2 ; 0-5(2 / 100)$ & $3 ; 0-6(3 / 100)$ \\
\hline
\end{tabular}

${ }^{a}$ Data are from Barber-Meyer et al. $2007 b$. 
Table 4. Ranking of 32 models estimating elk calf survival $(n=116)$ with covariates ${ }^{\mathrm{a}}$ and when $\hat{c}$ (a variance term) was 1.0 (i.e., assumed no dispersion) through 20 weeks post-radiotagging on the northern range of Yellowstone National Park, USA, 2003-2005. The selected models are in bold.

\begin{tabular}{|c|c|c|c|c|c|c|}
\hline Model & $\mathrm{AIC}_{c}^{\mathrm{b}}$ & $\Delta \mathrm{AIC}_{c}$ & $\mathrm{AIC}_{c} \mathrm{wt}$ & Model likelihood & No. par. ${ }^{b}$ & Deviance \\
\hline 1. $S\left(1-2,3-6,7-20 w k+a r e a \_6 w k+b d t d e v \_6 w k+b d t \_6 w k+G G \_6 w k\right)^{c}$ & 348.342 & 0.00 & 0.16417 & 1.0000 & 9 & 330.134 \\
\hline 2. S(1-2,3-6,7-20wk+area_6wk+bdtdev_6wk+bdt_6wk+T4_6wk $)^{c}$ & 349.308 & 0.97 & 0.10125 & 0.6167 & 9 & 331.100 \\
\hline 3. $S\left(1-2,3-6,7-20 w k+a r e a \_6 w k+b d t d e v \_6 w k+b d t \_6 w k\right)^{c}$ & 349.803 & 1.46 & 0.07908 & 0.4817 & 8 & 333.637 \\
\hline 4. S(1-2,3-6,7-20wk+area_6wk+bdtdev_6wk+bdt_6wk+IBR_6wk $)^{c}$ & 349.832 & 1.49 & 0.07792 & 0.4746 & 9 & 331.625 \\
\hline 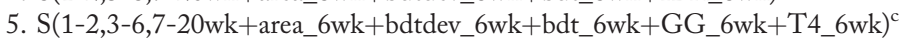 & 349.855 & 1.51 & 0.07703 & 0.4692 & 10 & 329.601 \\
\hline 6. $S\left(1-2,3-6,7-20 w k+a r e a \_6 w k+b d t d e v \_6 w k+G G \_6 w k\right)^{c}$ & 349.901 & 1.56 & 0.07530 & 0.4587 & 8 & 333.735 \\
\hline 7. S(1-2,3-6,7-20wk+area_6wk+bdtdev_6wk+T4_6wk $)^{c}$ & 350.266 & 1.92 & 0.06272 & 0.3820 & 8 & 334.100 \\
\hline 8. $\mathrm{S}(1-2,3-6,7-20 w \mathrm{w}+\text { area_6wk+bdtdev_6wk+IBR_6wk })^{\mathrm{c}}$ & 350.913 & 2.57 & 0.04539 & 0.2765 & 8 & 334.747 \\
\hline 9. S(1-2,3-6,7-20wk+area_6wk +bdtdev_6wk ${ }^{\text {d }}$ & 350.995 & 2.65 & 0.04356 & 0.2653 & 7 & 336.866 \\
\hline 10. $S(1-2,3-6,7-20 w k+\text { area_6wk }+ \text { GG_6wk })^{d}$ & 351.066 & 2.72 & 0.04206 & 0.2562 & 7 & 336.937 \\
\hline 11. $S\left(1-2,3-6,7-20 w k+a r e a-6 w k+b d t d e v \_6 w k+b d t d e v^{2} \_6 w k\right)^{e}$ & 351.398 & 3.06 & 0.03561 & 0.2169 & 8 & 335.232 \\
\hline 12. $\mathrm{S}(1-2,3-6,7-20 \mathrm{wk}+\text { area_6wk+T4_6wk })^{\mathrm{f}}$ & 351.459 & 3.12 & 0.03454 & 0.2104 & 7 & 337.330 \\
\hline 13. $\mathrm{S}(1-2,3-6,7-20 w \mathrm{w}+\text { area_6wk+bdt_6wk })^{\mathrm{f}}$ & 351.706 & 3.36 & 0.03054 & 0.1860 & 7 & 337.577 \\
\hline 14. S(1-2,3-6,7-20wk+area_6wk+IBR_6wk $)^{\mathrm{f}}$ & 352.622 & 4.28 & 0.01931 & 0.1176 & 7 & 338.494 \\
\hline 15. $S\left(1-2,3-6,7-20 w k+\text { area_6wk }+G_{G} 6 w k+G^{2} \_6 w k\right)^{e}$ & 352.748 & 4.41 & 0.01813 & 0.1104 & 8 & 336.582 \\
\hline 16. $S(1-2,3-6,7-20 \mathrm{wk}+$ area_6wk $)$ & 353.222 & 4.88 & 0.01431 & 0.0872 & 6 & 341.125 \\
\hline 17. $S(1-2,3-6,7-20 w k+$ area_6wk+IL-6_6wk $)$ & 353.457 & 5.12 & 0.01272 & 0.0775 & 7 & 339.328 \\
\hline 18. $S(1-2,3-6,7-20 w k+$ area_6wk+age_6wk $)$ & 354.138 & 5.80 & 0.00905 & 0.0551 & 7 & 340.009 \\
\hline 19. S(1-2,3-6,7-20wk+area_6wk+PI-3_6wk) & 354.585 & 6.24 & 0.00724 & 0.0441 & 7 & 340.457 \\
\hline 20. S(1-2,3-6,7-20wk+area_6wk+sex_6wk) & 354.609 & 6.27 & 0.00715 & 0.0436 & 7 & 340.480 \\
\hline 21. S(1-2,3-6,7-20wk+area_6wk+BUN_6wk) & 354.614 & 6.27 & 0.00713 & 0.0434 & 7 & 340.485 \\
\hline 22. S(1-2,3-6,7-20wk+area_6wk+GGT_6wk) & 354.707 & 6.37 & 0.00681 & 0.0415 & 7 & 340.578 \\
\hline 23. S(1-2,3-6,7-20wk+area_6wk+IGF-1_6wk) & 354.783 & 6.44 & 0.00656 & 0.0400 & 7 & 340.654 \\
\hline 24. $S\left(1-2,3-6,7-20 w k+a r e a \_6 w k+b m s \_6 w k\right)$ & 354.992 & 6.65 & 0.00591 & 0.0360 & 7 & 340.863 \\
\hline 25. $\mathrm{S}(1-2,3-6,7-20 \mathrm{wk} \times$ area_6wk $)$ & 355.042 & 6.70 & 0.00576 & 0.0351 & 9 & 336.834 \\
\hline 26. $S\left(1-2,3-6,7-20 w k+\right.$ area_6wk+TNF- $\left.\alpha \_6 w k\right)$ & 355.131 & 6.79 & 0.00551 & 0.0336 & 7 & 341.003 \\
\hline 27. S(1-2,3-6,7-20wk+area_6wk+BVD-1_6wk) & 355.227 & 6.88 & 0.00525 & 0.0320 & 7 & 341.098 \\
\hline 28. $S(1-2,3-6,7-20 w k)$ & 371.249 & 22.91 & 0.00000 & 0.0000 & 3 & 365.221 \\
\hline 29. S(1-2,3-6,7-20wk+year_6wk) & 373.780 & 25.44 & 0.00000 & 0.0000 & 5 & 363.711 \\
\hline 30. $S(1-2,3-6,7-20 w k$ x year_6wk) & 377.076 & 28.73 & 0.00000 & 0.0000 & 7 & 362.947 \\
\hline 31. S(each_wk_20wk) & 389.152 & 40.81 & 0.00000 & 0.0000 & 20 & 348.171 \\
\hline 32. S(constant) & 532.980 & 184.64 & 0.00000 & 0.0000 & 1 & 530.975 \\
\hline
\end{tabular}

${ }^{a}$ We evaluated covariates including capture area (area), capture year (year), capture age (age), sex, birth date (bdt), birth mass (bms), absolute deviation from median birth date (bdtdev), thyroxine (T4), serum urea nitrogen (SUN), $\gamma$-glutamyltransferase (GGT), gamma globulins (GG), interleukin (IL)-6, tumor necrosis factor (TNF)$\alpha$, insulin-like growth factor-1 (IGF-1), bovine-viral-diarrhea virus type 1 (BVD-1), infectious-bovine rhinotracheitis (IBR), and bovine parainfluenza-3 (PI-3).

${ }^{\mathrm{b}} \mathrm{AIC}_{c}=$ Akaike's Information Criterion adjusted for small sample size; no. par = no. of parameters.

${ }^{c}$ The $95 \%$ CI for the $\beta$ estimates of the parameter last added and one more parameter in these models contained zero when the last variable was added, so these models were not considered when selecting the model with the lowest $\mathrm{AIC}_{c}$.

${ }^{\mathrm{d}}$ These selected models included life-stage effects (weeks 1-2, 3-6, and 7-20), an additive area effect during weeks 1-6 (area_6wk; calving areas including Stephens Creek/Mammoth, Swan Lake Flats, Blacktail Deer Plateau/Tower, and Lamar Valley), and either an additive absolute deviation from the median birth date effect during weeks 1-6 (bdtdev_6wk) or an additive gamma globulin concentration effect during weeks 1-6 (GG_6wk).

${ }^{\mathrm{e}}$ Although these models were within $\Delta \mathrm{AIC}_{c}<2$ of the selected models [S(1-2,3-6,7-20wk+area_6wk+bdtdev_6wk) and S(1-2,3-6,7-20wk+area_6wk+GG_6wk)], adding the quadratic form of the covariates did not lower the $\mathrm{AIC}_{c}$, so these models were not selected.

${ }^{\mathrm{f}}$ The $95 \%$ CI for the $\beta$ estimate of the parameter last added and one more parameter in each of these models contained zero when the last variable was added, so these models were not considered candidate models, although they were within $\Delta \mathrm{AIC}_{c}<2$ of the selected models, [S(1-2,3-6,7-20wk+area_6wk+bdtdev_6wk) and S(1-2,3-6,720wk+area_6wk+GG_6wk)].

those captured in the Lamar Valley area $(0.11$ for bdtdev model and 0.10 for GG model, $n=33$; Table 6). Absolute deviation from the median birth date was negatively correlated with survival, and calves with higher GG had increased survival through week 6 after radiotagging (Table 7). Because the survival estimates we derived from both models were so similar, we used the estimates from the bdtdev model (i.e., the model with the lower $\mathrm{AIC}_{c}$ ) for summary purposes. Subsequent exploratory investigations supported our separation of summer survival into these 3 periods rather than lumping either the 1-2-week period with the 3-6-week period or the 3-6-week period with the 7-20-week period (these alternate models ranged from $\Delta \mathrm{AIC}_{c}=11-52$ more than the model with 3 periods).

Winter (Nov-Apr) survival was high $(0.90, \mathrm{SE}=0.05, n=42)$ compared with summer survival. This estimate of winter survival was similar to the finite survival rate observed during the same period (Nov-Apr, 0.86-0.90, $n=42$, depending on whether censored animals were considered alive or dead). Estimated survival during November-December and March-April was 1.00 $(\mathrm{SE}=0.00)$ and $0.95(\mathrm{SE}=0.03)$ during January-February. This model was the only candidate model within $\Delta \mathrm{AIC}_{c}<2$ when $\hat{c}$ was 1.0, 2.0, and 3.0. Neither capture year nor capture area was included in any candidate models for winter survival within $\Delta \mathrm{AIC}_{c}$ $<2$ (Table 8).

Annual survival was estimated as $0.22(\mathrm{SE}=0.04, n=149)$. The $95 \%$ confidence interval for this estimate $(0.15-0.29)$ contained the observed finite survival rate during the same period (0.24$0.30, n=151$, depending on whether censored animals were considered alive or dead). The selected annual survival model included 3 periods grouped by similar survival and an additive 
Table 5. Equations generated from known-fates models (Program MARK) to estimate life-stage and area-specific survival estimates for northern Yellowstone elk calves, 2003-2005, through 20 weeks post-radiotagging and May-April with standardized covariates (i.e., [variable value - variable mean]/variable SD).

Model

Model through 20 weeks post-radiotagging containing life-stage effects, an additive capture area effect during weeks $1-6$, and an additive absolute deviation from the median birth date effect during weeks 1-6 (bdtdev); $\mathrm{S}(1-2,3-6,7-20 \mathrm{wk}+$ area_6wk+bdtdev_6wk)

Model through 20 weeks post-radiotagging containing life-stage effects, an additive capture area effect during weeks $1-6$, and an additive gamma globulin (GG) concentration effect during weeks 1-6; S(1-2,3-6,720wk+area_6wk+GG_6wk)

Model during May-Apr containing temporal effects and an additive capture area effect during May-Jun; S(May-Jun,Jul-Oct\&Jan-Feb,Nov-Dec\&MarApr+area_only May-Jun)
Equation

Logit $=(0.6323165 \times 1$ if during weeks $1-2$, otherwise $\times 0)+(2.6757005$ $\times 1$ if during weeks $3-6$, otherwise $\times 0)+(4.8323055 \times 1$ if during weeks $7-20$, otherwise $\times 0)+(0.8459554 \times 1$ if in Stephens Creek/ Mammoth calving area, otherwise $\times 0)+(0.0977533 \times 1$ if in Swan Lake Flats calving area, otherwise $\times 0)+(0.4819465 \times 1$ if in Blacktail Deer Plateau/Tower calving area, otherwise $\times 0)+(-0.3343158 \times$ bdtdev)

Logit $=(0.6396822 \times 1$ if during weeks $1-2$, otherwise $\times 0)+(2.6980935$ $\times 1$ if during weeks $3-6$, otherwise $\times 0)+(4.8323057 \times 1$ if during weeks $7-20$, otherwise $\times 0)+(0.7967472 \times 1$ if in Stephens Creek/ Mammoth calving area, otherwise $\times 0)+(0.1913007 \times 1$ if in Swan Lake Flats calving area, otherwise $\times 0)+(0.4921120 \times 1$ if in Blacktail Deer Plateau/Tower calving area, otherwise $\times 0)+(0.3067064 \times$ GG $)$

Logit $=(0.1732566 \times 1$ if during weeks May-Jun, otherwise $\times 0)+$ $(2.9292665 \times 1$ if during Jul-Oct or Jan-Feb, otherwise $\times 0)+$ $(20.514586 \times 1$ if during Nov-Dec or Mar-Apr, otherwise $\times 0)+$ $(0.7297802 \times 1$ if in Stephens Creek/Mammoth calving area, otherwise $\times 0)+(0.1578208 \times 1$ if in Swan Lake Flats calving area, otherwise $\times$ $0)+(0.2630197 \times 1$ if in Blacktail Deer Plateau/Tower calving area, otherwise $\times 0$ ) capture-area effect during May-June (Table 9). Survival across the 3 periods was $0.54(\mathrm{SE}=0.04)$ during May-June, $0.95(\mathrm{SE}=$ 0.01 ) during July-October and January-February, and 1.00 (SE $=$ 0.00) during November-December and March-April. Capture year was not included in the model with the lowest $\mathrm{AIC}_{c}$, and there was no other candidate model within $\Delta \mathrm{AIC}_{c}<2$ when $\hat{c}$ was 1.0. When $\hat{c}$ was 2.0 and 3.0, the selected model remained the model with the lowest QAIC $_{c}$

We used an equation (Table 5) generated in Program MARK from the known-fates model to estimate area-specific survival estimates during May-April with standardized covariates (i.e., [variable value - variable mean]/variable SD). We then estimated the May-June component of annual survival of elk born in various calving areas as $\left(e^{\text {Logit }}\right) /\left(1+e^{\text {Logit }}\right)$ as per Cooch and White (2002). We squared this estimate (2 months) and multiplied by the estimate for survival pooled across all areas during JulyOctober and January-February (6 months) to the sixth power and multiplied by the estimate for survival pooled across all areas

Table 6. Probability of summer ${ }^{\mathrm{a}}$ (20 weeks post-radiotagging) and annual (MayApr) calf-elk survival by capture area on the northern range of Yellowstone National Park, USA, 2003-2005.

\begin{tabular}{llcl}
\hline \multicolumn{1}{c}{ Capture area } & Period & Survival probability & $\boldsymbol{n}$ \\
\hline \multirow{2}{*}{ Stephens Creek/Mammoth } & Summer & $0.60,0.57$ & 29 \\
& Annual & 0.54 & 39 \\
Swan Lake Flats & Summer & $0.15,0.19$ & 29 \\
\multirow{5}{*}{ Blacktail Deer Plateau/Tower } & Annual & 0.18 & 37 \\
& Summer & $0.40,0.40$ & 25 \\
Lamar Valley & Annual & 0.34 & 30 \\
& Summer & $0.11,0.10$ & 33 \\
& Annual & 0.17 & 43
\end{tabular}

${ }^{a}$ The first summer survival estimate is from the selected model containing birthdate-deviation [S(1-2,3-6,7-20wk+area_6wk+bdtdev_6wk); survival during weeks $1-2,3-6$, and 7-20; and additive effects of capture area and absolute deviation from median birth date during weeks 1-6] and the second estimate is from the selected model containing gamma globulins [GG; S(1-2,3-6,7-20wk+area_6wk+GG_6wk); survival during weeks $1-2,3-6$, and 7-20; and additive effects of capture area and GG concentrations during weeks 1-6]. during November-December and March-April (4 months) to the fourth power to calculate annual survival for elk calves born in various calving areas (Table 6). We used Program MARK to generate the estimates for survival during July-October, JanuaryFebruary, November-December, and March-April. Animals captured in the Stephens Creek/Mammoth area had an average annual survival probability $>3 \times$ higher $(0.54)$ than those captured in the Lamar Valley (0.17; Table 6).

\section{Cause-Specific Mortality}

Sixty-nine percent $(n=104)$ of calves $(n=151)$ died within their first year, 24\% $(n=36)$ survived their first year, and $7 \%(n=11)$

Table 7. Survival point estimates of northern Yellowstone elk calves during 20032005 in Yellowstone National Park, USA, while varying one covariate with others held constant at means through 20 weeks after capture in different calving areas. Covariates include absolute deviation from median birth date (days) and gamma globulins $(\mathrm{g} / \mathrm{dL})$.

\begin{tabular}{|c|c|c|c|c|}
\hline Covariate & $\begin{array}{l}\text { Stephens } \\
\text { Creek/ } \\
\text { Mammoth }\end{array}$ & $\begin{array}{l}\text { Swan } \\
\text { Lake } \\
\text { Flats }\end{array}$ & $\begin{array}{l}\text { Blacktail } \\
\text { Deer } \\
\text { Plateau/ } \\
\text { Tower }\end{array}$ & $\begin{array}{l}\text { Lamar } \\
\text { Valley }\end{array}$ \\
\hline \multicolumn{5}{|c|}{ Absolute deviation from median birth date } \\
\hline Max. premedian (16 May) & 0.44 & 0.05 & 0.22 & 0.03 \\
\hline 10 days premedian (19 May) & 0.51 & 0.09 & 0.30 & 0.06 \\
\hline First quartile (22 May) & 0.58 & 0.13 & 0.37 & 0.09 \\
\hline 5 days premedian (24 May) & 0.62 & 0.17 & 0.42 & 0.12 \\
\hline Median (29 May) & 0.70 & 0.28 & 0.54 & 0.22 \\
\hline 5 days post-median (3 Jun) & 0.62 & 0.17 & 0.42 & 0.12 \\
\hline Third quartile ( 3 Jun) & 0.62 & 0.17 & 0.42 & 0.12 \\
\hline 10 days post-median ( 8 Jun) & 0.51 & 0.09 & 0.30 & 0.06 \\
\hline Max. post-median (10 Jun) & 0.47 & 0.06 & 0.25 & 0.039 \\
\hline \multicolumn{5}{|l|}{ Gamma globulins } \\
\hline Min. $(0.0 \mathrm{~g} / \mathrm{dL})$ & 0.42 & 0.08 & 0.24 & 0.04 \\
\hline First quartile $(0.975 \mathrm{~g} / \mathrm{dL})$ & 0.52 & 0.15 & 0.34 & 0.07 \\
\hline Median $(1.50 \mathrm{~g} / \mathrm{dL})$ & 0.57 & 0.19 & 0.40 & 0.10 \\
\hline Third quartile $(2.125 \mathrm{~g} / \mathrm{dL})$ & 0.62 & 0.25 & 0.46 & 0.15 \\
\hline Max. $(3.30 \mathrm{~g} / \mathrm{dL})$ & 0.70 & 0.37 & 0.58 & 0.25 \\
\hline
\end{tabular}


Table 8. Ranking of 7 models estimating winter elk calf survival ( $n=42)$ during November-April (2003-2006) on the northern range of Yellowstone National Park, USA. The selected model (when $\hat{c}$, a variance term, was 1.0; i.e., assumed no dispersion in the data) is in bold.

\begin{tabular}{|c|c|c|c|c|c|c|}
\hline Model $^{\mathbf{a}}$ & $\mathrm{AIC}_{c}^{\mathrm{b}}$ & $\Delta \mathrm{AIC}_{c}$ & $\mathrm{AIC}_{c} \mathrm{wt}$ & Model likelihood & No. par. & Deviance \\
\hline 1. S(Nov-Dec\&Mar-Apr,Jan-Feb) ${ }^{c}$ & 35.501 & 0.00 & 0.67803 & 1.0000 & 2 & 31.449 \\
\hline 2. S(Nov-Dec\&Mar-Apr,Jan-Feb+area) & 38.295 & 2.79 & 0.16770 & 0.2473 & 5 & 28.029 \\
\hline 3. S(Nov-Dec\&Mar-Apr,Jan-Feb+year) & 39.391 & 3.89 & 0.09697 & 0.1430 & 4 & 31.214 \\
\hline 4. $\mathrm{S}$ (constant) & 42.397 & 6.90 & 0.02157 & 0.0318 & 1 & 40.379 \\
\hline 5. S(different each month) & 42.880 & 7.38 & 0.01694 & 0.0250 & 6 & 30.505 \\
\hline 6. S(Nov-Dec\&Mar-Apr,Jan-Feb x year) & 43.589 & 8.09 & 0.01189 & 0.0175 & 6 & 31.214 \\
\hline 7. S(Nov-Dec\&Mar-Apr,Jan-Feb x area) & 44.677 & 9.18 & 0.00690 & 0.0102 & 8 & 28.029 \\
\hline
\end{tabular}

${ }^{a}$ We evaluated covariates including capture area (area) and capture year (year).

${ }^{\mathrm{b}} \mathrm{AIC}_{c}=$ Akaike's Information Criterion adjusted for small sample size; no. par. = no. of parameters.

${ }^{c}$ This model included a parameter to estimate survival during both Nov-Dec and Mar-Apr and another to estimate survival during Jan-Feb.

had unknown fates (Table 10). Of the 11 calves with unknown fates, 2 calves were missing, 7 lost their transmitters, and we could not examine 2 possible mortality sites. Of elk calves with known fates during their first year of life $(n=140), 74 \%$ died $(n=104)$ and $26 \%$ survived $(n=36)$. Most calf deaths during the first year of life occurred within 30 days of birth (86\% of confirmed deaths, $n=89$ of 104 and $59 \%$ of all captured calves, $n=89$ out of 151 ; Fig. 2). Predators killed $\geq 65 \%$ of all captured calves $(n=98$ of 151). Causes of death were similar across years (Table 10), and bears accounted for 58-60\% (60-62 of 104 deaths; grizzly bears accounted for $\geq 33$ deaths, black bears accounted for $\geq 21$, and bears of unknown species accounted for 6-8 deaths) of confirmed deaths (40-41\% of calves captured), wolves accounted for $14-17 \%$ (15-18 of 104 deaths) of confirmed deaths (11-13\% of calves captured), and coyotes accounted for 10-11\% (10-11 of 104 deaths) of confirmed deaths ( $7 \%$ of calves captured), depending on the cause of 2 deaths recorded wolf or bear and one recorded wolf or coyote (both species were at the elk calf mortality sites; Table 10).

Predators caused 94\% ( $n=98$ of 104) of confirmed deaths, and $77 \%(n=75$ of 98$)$ and $86 \%(n=84$ of 98$)$ of this predation occurred within the first 15 and 30 days after birth, respectively. Bears accounted for 69\% $(n=58)$ of all predation deaths during the first 30 days after birth $(n=84)$; specifically, grizzly bears accounted for 32 deaths, $38 \%$ of all predation deaths; black bears 20, 24\%; and unknown bears 6, 7\%. Coyotes and wolves accounted for $11 \%(n=9)$ and $12 \%(n=10)$, respectively. One calf about 16 days old died of pneumonia (Smits 1992) and one calf about 25 days old died of possible fluoride toxicosis evidenced by stained teeth, which has been reported in ungulates foraging near geothermic areas (Shupe et al. 1984, Vikoren and Stuve 1996, Garrott et al. 2002). Mean calf age at death was 10 days $(S D=8)$ for bear kills (9 days for grizzly bear kills $[\mathrm{SD}=7], 12$ days for black bear kills $[\mathrm{SD}=10]), 29$ days $(\mathrm{SD}=72)$ for coyote kills, 35 days $(\mathrm{SD}=53)$ for wolf kills, and 107 days $(\mathrm{SD}=24)$ for cougar kills (Fig. 3).

Calves born during the peak of calving were less likely to be killed by bears $(0.37, \mathrm{SE}=0.07)$ than those born prepeak $(0.41$, $\mathrm{SE}=0.07)$ and post-peak $(0.54, \mathrm{SE}=0.07)$, although this difference was not statistically significant $\left(P=0.16, F_{2,101}=1.87\right)$. Calves born in the Stephens Creek/Mammoth and Mount Everts/ Blacktail Deer Plateau/Tower areas were less likely to be killed by bears $(0.21, \mathrm{SE}=0.07$ and $0.26, \mathrm{SE}=0.09$, respectively) or by all predators combined $(0.45, \mathrm{SE}=0.09$ and $0.76, \mathrm{SE}=0.08$, respectively) than calves born in Swan Lake Flats (0.68 bears, SE $=0.08$ and 0.78 all predators, $\mathrm{SE}=0.07)$ and Lamar Valley $(0.58$ bears, $\mathrm{SE}=0.08$ and 0.83 all predators, $\mathrm{SE}=0.07 ; P=0.01, F_{3,101}$ $=4.32$ for bears; $P=0.04, F_{3,106}=2.93$ for all predators; Fig. 4). Probability of being killed by a bear did not vary by year, sex, or any 2-way interactions between those variables or by interactions with birth period and calving area. Probability of being killed by predation did not vary by capture year, birth period, sex, or any 2way interactions between those variables and between those variables and calving area. Due to small samples, we could not

Table 9. Ranking of 8 models estimating annual elk calf survival $(n=149)$ May-April on the northern range of Yellowstone National Park, USA, 2003-2005. The selected model (when $\hat{c}$, a variance term, was 1.0; i.e., assumed no dispersion in the data) is in bold.

\begin{tabular}{|c|c|c|c|c|c|c|}
\hline Model $^{\mathrm{a}}$ & $\mathrm{AIC}_{c}^{\mathrm{b}}$ & $\Delta \mathrm{AIC}_{c}$ & $\mathrm{AIC}_{c} \mathrm{wt}$ & Model likelihood & No. par. ${ }^{b}$ & Deviance \\
\hline 1. S(May-Jun,Jul-Oct\&Jan-Feb,Nov-Dec\&Mar-Apr+area_only May-Jun) ${ }^{c}$ & 374.976 & 0.00 & 0.71084 & 1.0000 & 6 & 362.840 \\
\hline 2. S(May-Jun,Jul-Oct\&Jan-Feb,Nov-Dec\&Mar-Apr+area) & 377.063 & 2.09 & 0.25039 & 0.3522 & 6 & 364.927 \\
\hline 3. S(May-Jun,Ju1-Oct\&Jan-Feb,Nov-Dec\&Mar-Apr x area) & 380.901 & 5.93 & 0.03674 & 0.0517 & 12 & 356.392 \\
\hline 4. S(May-Jun,Jul-Oct\&Jan-Feb,Nov-Dec\&Mar-Apr) & 387.200 & 12.22 & 0.00158 & 0.0022 & 3 & 381.161 \\
\hline 5. S(May-Jun,Jul-Oct\&Jan-Feb,Nov-Dec\&Mar-Apr+year) & 389.783 & 14.81 & 0.00043 & 0.0006 & 5 & 379.686 \\
\hline 6. S(May-Jun,Jul-Oct\&Jan-Feb,Nov-Dec\&Mar-Apr x year) & 396.195 & 21.22 & 0.00002 & 0.0000 & 9 & 377.903 \\
\hline 7. S(different each month) & 399.182 & 24.21 & 0.00000 & 0.0000 & 12 & 374.672 \\
\hline 8. S(constant) & 565.035 & 190.06 & 0.00000 & 0.0000 & 1 & 563.028 \\
\hline
\end{tabular}

\footnotetext{
${ }^{a}$ We evaluated covariates including capture area (area) and capture year (year).

${ }^{\mathrm{b}} \mathrm{AIC}_{c}=$ Akaike's Information Criterion adjusted for small sample size; no. par. = no. of parameters.

${ }^{\mathrm{c}}$ This model included parameters to estimate survival during 1) May-Jun, 2) Jul-Oct and Jan-Feb, and 3) Nov-Dec and Mar-Apr and an additive area effect (3 additional parameters for 4 calving areas) during May-Jun (calving areas including Stephens Creek/Mammoth, Swan Lake Flats, Blacktail Deer Plateau/Tower, and Lamar Valley).
} 
Table 10. Number of calf fates (\% of sample at the start of each period) attributable to predation, nonpredation, or unknown fate, and confirmed survivors ${ }^{a}$ during the first summer (birth-31 Oct), winter (1 Nov-30 Apr), and year of life (birth-30 Apr) of northern Yellowstone elk calves, Yellowstone National Park, USA, $2003-2005$.

\begin{tabular}{|c|c|c|c|c|c|c|c|c|c|c|c|c|}
\hline \multirow[b]{2}{*}{ Fate } & \multicolumn{3}{|c|}{2003} & \multicolumn{3}{|c|}{2004} & \multicolumn{3}{|c|}{2005} & \multicolumn{3}{|c|}{$2003-2005$} \\
\hline & Summer & Winter & Annual & Summer & Winter & Annual & Summer & Winter & Annual & Summer & Winter & Total \\
\hline \multicolumn{13}{|l|}{ Predation } \\
\hline Bear & $20(39)$ & $0(0)$ & $20(39)$ & $17(39)$ & $0(0)$ & $17(39)$ & $23(41)$ & $0(0)$ & $23(41)$ & $60(40)$ & $0(0)$ & $60(40)$ \\
\hline Grizzly bear & $11(22)$ & $0(0)$ & $11(22)$ & $7(16)$ & $0(0)$ & $7(16)$ & $15(27)$ & $0(0)$ & $15(27)$ & $33(22)$ & $0(0)$ & $33(22)$ \\
\hline Black bear & $6(12)$ & $0(0)$ & $6(12)$ & $7(16)$ & $0(0)$ & $7(16)$ & $8(14)$ & $0(0)$ & $8(14)$ & $21(14)$ & $0(0)$ & $21(14)$ \\
\hline Unknown bear & $3(6)$ & $0(0)$ & $3(6)$ & $3(7)$ & $0(0)$ & $3(7)$ & $0(0)$ & $0(0)$ & $0(0)$ & $6(4)$ & $0(0)$ & $6(4)$ \\
\hline Wolf & $4(8)$ & $0(0)$ & $4(8)$ & $3(7)$ & $1(8)$ & $4(9)$ & $7(13)$ & $0(0)$ & $7(13)$ & $14(9)$ & $1(2)$ & $15(10)$ \\
\hline Coyote & $3(6)$ & $1(6)$ & $4(8)$ & $4(9)$ & $0(0)$ & $4(9)$ & $2(4)$ & $0(0)$ & $2(4)$ & $9(6)$ & $1(2)$ & $10(7)$ \\
\hline Wolf/bear (both present) & $1(2)$ & $0(0)$ & $1(2)$ & $1(2)$ & $0(0)$ & $1(2)$ & $0(0)$ & $0(0)$ & $0(0)$ & $2(1)$ & $0(0)$ & $2(1)$ \\
\hline Wolf/coyote (both present) & $0(0)$ & $0(0)$ & $0(0)$ & $0(0)$ & $0(0)$ & $0(0)$ & $0(0)$ & $1(7)$ & $1(2)$ & $0(0)$ & $1(2)$ & $1(1)$ \\
\hline Cougar & $1(2)$ & $0(0)$ & $1(2)$ & $0(0)$ & $0(0)$ & $0(0)$ & $2(4)$ & $0(0)$ & $2(4)$ & $3(2)$ & $0(0)$ & $3(2)$ \\
\hline Wolverine (Gulo gulo) & $1(2)$ & $0(0)$ & $1(2)$ & $0(0)$ & $0(0)$ & $0(0)$ & $0(0)$ & $0(0)$ & $0(0)$ & $1(1)$ & $0(0)$ & $1(1)$ \\
\hline Golden eagle (Aquila chrysaetos) ${ }^{\mathrm{b}}$ & $0(0)$ & $0(0)$ & $0(0)$ & $1(2)$ & $0(0)$ & $1(2)$ & $0(0)$ & $0(0)$ & $0(0)$ & $1(1)$ & $0(0)$ & $1(1)$ \\
\hline Hunter & $0(0)$ & $1(6)$ & $1(2)$ & $0(0)$ & $0(0)$ & $0(0)$ & $0(0)$ & $0(0)$ & $0(0)$ & $0(0)$ & $1(2)$ & $1(1)$ \\
\hline Unknown predator & $1(2)$ & $0(0)$ & $1(2)$ & $1(2)$ & $0(0)$ & $1(2)$ & $3(5)$ & $0(0)$ & $3(5)$ & $5(3)$ & $0(0)$ & $5(3)$ \\
\hline \multicolumn{13}{|l|}{ Nonpredation or unknown fate } \\
\hline Not predation ${ }^{c}$ & $2(4)$ & $0(0)$ & $2(4)$ & $2(5)$ & $0(0)$ & $2(5)$ & $1(2)$ & $0(0)$ & $1(2)$ & $5(3)$ & $0(0)$ & $5(3)$ \\
\hline Missing & $1(2)$ & $0(0)$ & $1(2)$ & $1(2)$ & $0(0)$ & $1(2)$ & $0(0)$ & $0(0)$ & $0(0)$ & $2(1)$ & $0(0)$ & $2(1)$ \\
\hline Transmitter pull-out & $0(0)$ & $0(0)$ & $0(0)$ & $2(5)$ & $1(8)$ & $3(7)$ & $3(5)$ & $1(7)$ & $4(7)$ & $5(3)$ & $2(5)$ & $7(5)$ \\
\hline Unknown $^{\mathrm{d}}$ & $1(2)$ & $0(0)$ & $1(2)$ & $0(0)$ & $0(0)$ & $0(0)$ & $1(2)$ & $0(0)$ & $1(2)$ & $2(1)$ & $0(0)$ & $2(1)$ \\
\hline Total possible nonsurvivors & $35(69)$ & $2(13)$ & $37(73)$ & $32(73)$ & $2(17)$ & $34(77)$ & $42(75)$ & $2(14)$ & $44(79)$ & $109(72)$ & $6(14)$ & $115(76)$ \\
\hline Confirmed survivors & $16(31)$ & $14(88)$ & $14(27)$ & $12(27)$ & $10(83)$ & $10(23)$ & $14(25)$ & $12(86)$ & $12(21)$ & $42(28)$ & $36(86)$ & $36(24)$ \\
\hline Beginning sample & 51 & 16 & 51 & 44 & 12 & 44 & 56 & 14 & 56 & 151 & 42 & 151 \\
\hline
\end{tabular}

${ }^{a}$ Confirmed survivors included animals that we were able to confirm as survivors by radiotelemetry. Missing and transmitter pull-out cases may have been survivors, but we were unable to confirm survival, so we included those cases in unknown fates.

${ }^{\mathrm{b}}$ Determination of predation in this case was not definitive.

${ }^{\mathrm{c}}$ In 2003, one calf likely drowned and another possibly died from excess fluoride. In 2004, one calf's lungs never fully expanded and another likely died from exposure to cold in a late spring snowstorm. In 2005, one calf likely died from pneumonia.

${ }^{\mathrm{d}}$ Due to fires or high waters, respectively, we could not examine one possible mortality in 2003 and one in 2005.

statistically compare blood values with cause of death while appropriately accounting for possible main effects and interactions of capture age, sex, capture year, and capture area. Nevertheless, the means of blood characteristics of calves killed by bears, wolves, and coyotes and those of annual survivors (capture-Apr) do not seem to greatly differ (Table 11).

During the winter (Nov-Apr) of 2003-2004 ( $n=16)$, one calf was legally shot outside the park and one died of coyote predation; during 2004-2005 $(n=12)$ one died of wolf predation, and we censored one due to a possible transmitter pull-out; and during

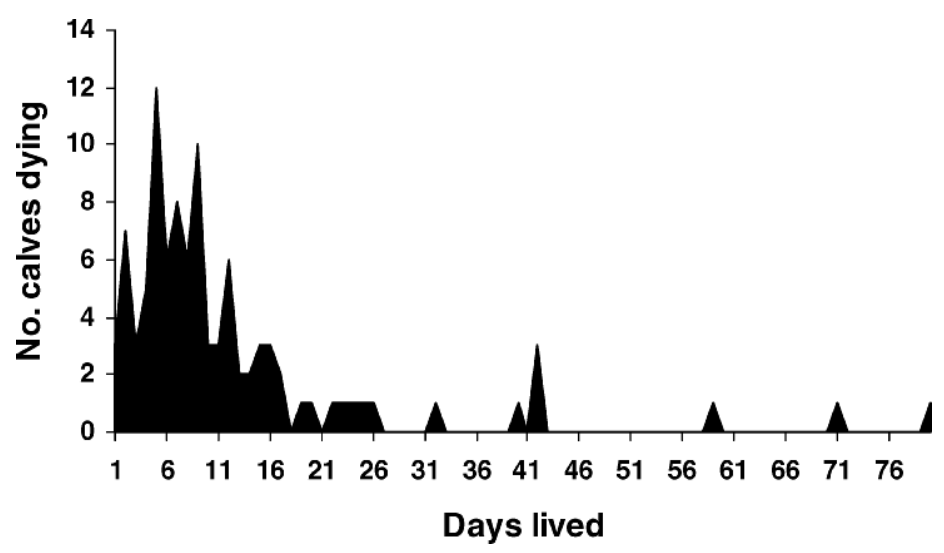

Figure 2. Mortality risk of northern Yellowstone elk calves studied in Yellowstone National Park, USA, during 2003-2005 from birth through 80 days $(n=99$ deaths).
2005-2006 $(n=14)$ one died of either wolf or coyote predation, and we censored one due to a possible transmitter pull-out. Excluding censored individuals during winter, $10 \%(n=4$ of 40$)$ of calves died during winter, none from malnutrition.

\section{Winter Migrations and Yearling Dispersal}

Of the 42 calves with functioning transmitters at the start of November, $48 \%$ ( $n=20$ of 42$)$ were originally captured in the

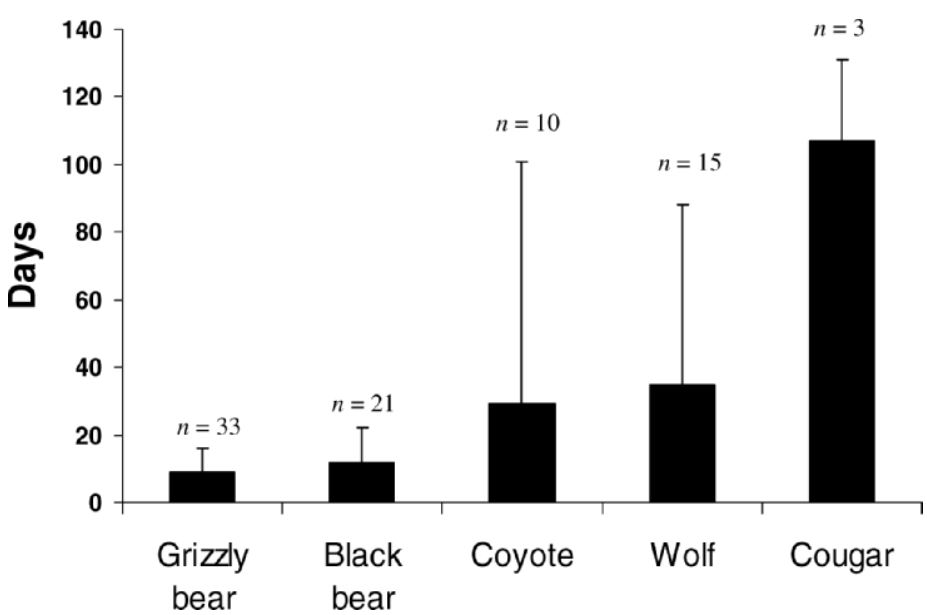

Figure 3. Mean age (days) at death of northern-range Yellowstone elk calves radiotagged in Yellowstone National Park, USA, during 2003-2005 and killed by various predators. 


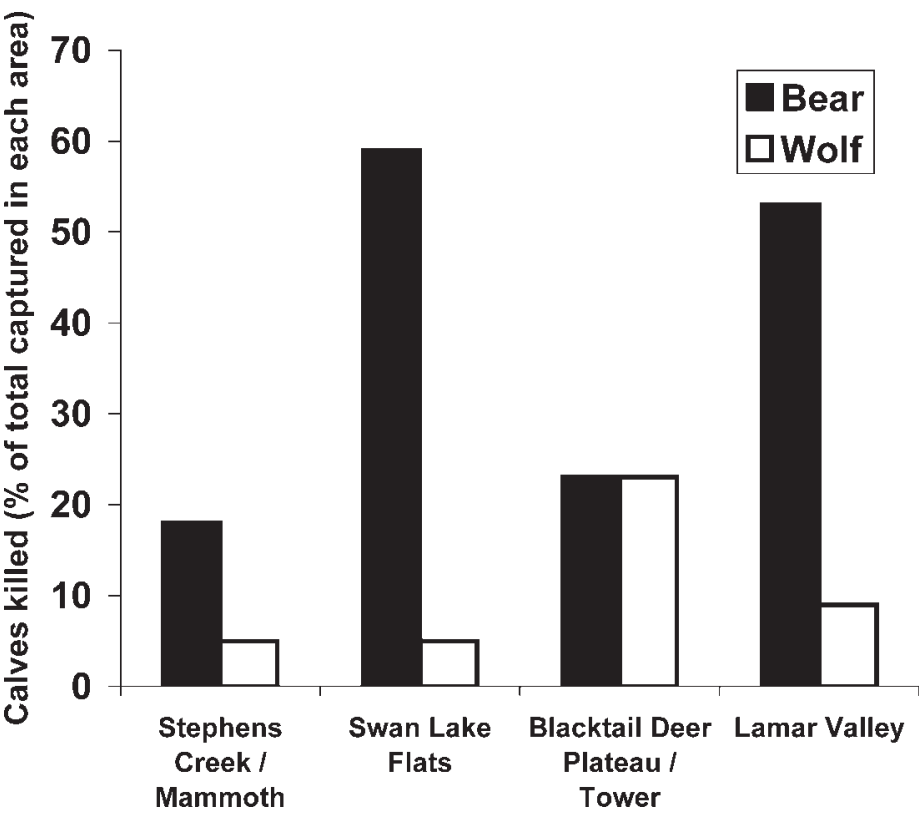

Figure 4. Percent of elk calves captured in each calving area killed by bears and wolves in Yellowstone National Park, USA, during 2003-2006.

Stephens Creek/Mammoth area, 19\% ( $n=8$ of 42) in the Swan Lake Flats area, 19\% ( $n=8$ of 42) in the Blacktail Deer Plateau/ Tower area, and $14 \%$ ( $n=6$ of 42$)$ in the Lamar Valley area. No calves captured in the Stephens Creek/Mammoth area migrated to a winter range, whereas all calves captured in the Lamar Valley area migrated to a different winter range (Table 12). At least 5 of the 6 calves that migrated from Lamar Valley survived, and the other calf likely had its transmitter fall out (Table 12).

Of the 32 calves with transmitters that functioned at least through their second summer (i.e., $>1$ yr), 2 likely dispersed out of YNP into adjacent elk herds before their transmitters ceased functioning. Two elk originally captured in the Stephens Creek/ Mammoth calving area during 2003 likely dispersed into 2 different herds: south to the Jackson elk herd and west to the Gallatin elk herd. Also, one calf captured in the Swan Lake Flats calving area during 2004 may have dispersed to the Gallatin elk herd during autumn 2004.

\section{DISCUSSION}

\section{Capture and Birth Characteristics}

We caught more female than male neonates (68M:83F) compared with 1987-1990 (73M:54F; Singer et al. 1997). This femalebiased sex ratio may indicate adult females were in poorer condition during 2003-2005 than 1987-1990 (Trivers and Willard 1973, Clutton-Brock et al. 1986, Smith et al. 1996). Our study was conducted during an extreme, 8-year drought (1998-2005; National Climate Data Center 2005) that may have reduced forage quality, diminished adult female condition, and, in turn, led to decreased reproductive rates and calf survival (Thorne et al. 1976, Clutton-Brock et al. 1982, Singer et al. 1997, Cook 2000). However, reproductive rates during our study were high (0.90) and similar to those before wolf restoration (White and Garrott 2005a). Our mean calf birth mass of $14.9 \mathrm{~kg}$ during 20032005 was in the low end of the range of values reported in freeranging elk (range $=14.8-16.8 \mathrm{~kg}$; Rush 1932, Johnson 1951, Schlegel 1976, Smith et al. 1997, Raithel 2005). However, estimated elk calf birth masses during 2003-2005 (range of yearly means $=14.1-14.8 \mathrm{~kg}$ ) were similar to those during 1987-1988 (yearly means $=13.8-14.9 \mathrm{~kg}$; Singer et al. 1997, fig. 1). Also, the body condition of 96 female northern Yellowstone elk during winters 2000-2002, as assessed using ultrasonography of subcutaneous rump fat, was characterized as "relatively good" for midto late winter (Feb-Mar), with only $4 \%$ of females at a level of condition indicative of elevated protein catabolism and high probability of mortality due to winter starvation (Cook et al.

Table 11. Values of blood ${ }^{\mathrm{a}}$ and morphometric characteristics at capture in elk calf survivors, nonsurvivors, those killed ${ }^{\mathrm{b}}$ by bears, wolves, or coyotes, and those dying from nonpredation sources from capture to April in the northern range of Yellowstone National Park, USA, during 2003-2005.

\begin{tabular}{|c|c|c|c|c|c|c|c|c|c|c|c|c|c|c|c|c|c|c|}
\hline & \multicolumn{3}{|c|}{ Survivors } & \multicolumn{3}{|c|}{ Nonsurvivors } & \multicolumn{3}{|c|}{ Bear } & \multicolumn{3}{|c|}{ Wolf } & \multicolumn{3}{|c|}{ Coyote } & \multicolumn{3}{|c|}{ Nonpredation } \\
\hline & $\bar{x}$ & $n$ & SE & $\bar{x}$ & $n$ & SE & $\bar{x}$ & $n$ & SE & $\bar{x}$ & $n$ & SE & $\bar{x}$ & $n$ & SE & $\bar{x}$ & $n$ & SE \\
\hline Thyroxine $(\mu \mathrm{g} / \mathrm{dL})$ & 12 & 31 & 0.80 & 17 & 94 & 1.7 & 17 & 56 & 2.3 & 21 & 14 & 6.4 & 13 & 9 & 1.3 & 11 & 3 & 3.6 \\
\hline Serum urea nitrogen $(\mathrm{mg} / \mathrm{dL})$ & 17 & 31 & 1.2 & 18 & 94 & 0.67 & 17 & 56 & 0.87 & 21 & 14 & 1.8 & 19 & 9 & 2.3 & 14 & 3 & 2.1 \\
\hline$\gamma$-Glutamyltransferase (IU/L) & 60 & 31 & 5.0 & 70 & 96 & 5.9 & 66 & 55 & 4.3 & 63 & 15 & 11 & 69 & 9 & 13 & 168 & 4 & 119 \\
\hline Insulin-like growth factor-1 (ng/mL) & 248 & 32 & 24 & 253 & 97 & 11 & 253 & 56 & 11 & 274 & 15 & 34 & 195 & 9 & 36 & 191 & 4 & 67 \\
\hline Gamma globulins ( $\mathrm{g} / \mathrm{dL})$ & 1.7 & 30 & 0.14 & 1.5 & 88 & 0.09 & 1.5 & 51 & 0.12 & 1.1 & 14 & 0.21 & 1.9 & 9 & 0.23 & 1.2 & 3 & 0.49 \\
\hline Interleukin-6 $(\mathrm{pg} / \mathrm{mL})$ & 0.12 & 32 & 0.05 & 0.05 & 98 & 0.01 & 0.06 & 57 & 0.01 & 0.05 & 15 & 0.02 & 0.05 & 9 & 0.02 & 0.05 & 4 & 0.02 \\
\hline Tumor necrosis factor- $\alpha(\mathrm{pg} / \mathrm{mL})$ & 7.4 & 32 & 2.5 & 11 & 100 & 2.9 & 10 & 58 & 4.3 & 23 & 15 & 8.4 & 7.1 & 10 & 5.5 & 5.9 & 4 & 3.9 \\
\hline Bovine-viral-diarrhea virus type 1 & 0.17 & 30 & 0.07 & 0.25 & 95 & 0.04 & 0.29 & 56 & 0.06 & 0.13 & 15 & 0.09 & 0.22 & 9 & 0.15 & 0.33 & 3 & 0.33 \\
\hline Infectious-bovine rhinotracheitis & 0.61 & 31 & 0.09 & 0.57 & 95 & 0.05 & 0.55 & 56 & 0.07 & 0.67 & 15 & 0.13 & 0.67 & 9 & 0.17 & 0.33 & 3 & 0.33 \\
\hline Bovine parainfluenza-3 & 0.30 & 30 & 0.09 & 0.34 & 94 & 0.05 & 0.36 & 55 & 0.07 & 0.33 & 15 & 0.13 & 0.56 & 9 & 0.18 & 0.00 & 3 & 0.00 \\
\hline Bovine-respiratory syncytial virus & 0.03 & 30 & 0.03 & 0.03 & 94 & 0.02 & 0.00 & 56 & 0.00 & 0.07 & 14 & 0.07 & 0.00 & 9 & 0.00 & 0.00 & 3 & 0.00 \\
\hline Brucellosis & 0.03 & 30 & 0.03 & 0.03 & 93 & 0.02 & 0.02 & 55 & 0.02 & 0.07 & 14 & 0.07 & 0.00 & 9 & 0.00 & 0.00 & 3 & 0.00 \\
\hline Female hind-foot length $(\mathrm{cm})$ & 40 & 13 & 0.87 & 40 & 35 & 0.52 & 40 & 23 & 0.63 & 40 & 3 & 1.8 & 41 & 2 & 0.25 & 31 & 1 & - \\
\hline Male hind-foot length $(\mathrm{cm})$ & 42 & 9 & 0.45 & 41 & 34 & 0.53 & 41 & 16 & 0.95 & 40 & 8 & 0.85 & 42 & 4 & 0.38 & 37 & 2 & 2.3 \\
\hline Female body-contour length $(\mathrm{cm})$ & 108 & 23 & 1.7 & 106 & 52 & 1.02 & 107 & 32 & 0.86 & 103 & 5 & 4.6 & 110 & 4 & 3.8 & 90 & 2 & 16 \\
\hline Male body-contour length $(\mathrm{cm})$ & 106 & 10 & 2.6 & 108 & 45 & 1.15 & 107 & 24 & 1.7 & 109 & 9 & 1.9 & 108 & 5 & 2.2 & 102 & 2 & 11 \\
\hline Female estimated birth mass $(\mathrm{kg})$ & 14 & 24 & 0.49 & 14 & 53 & 0.30 & 14 & 33 & 0.31 & 14 & 5 & 1.4 & 13 & 4 & 1.8 & 10 & 2 & 4.1 \\
\hline Male birth estimated mass $(\mathrm{kg})$ & 16 & 12 & 0.80 & 16 & 50 & 0.37 & 16 & 27 & 0.55 & 16 & 10 & 0.78 & 15 & 6 & 0.43 & 15 & 2 & 3.4 \\
\hline
\end{tabular}

a Disease seroprevalence is the no. of calves positive/the total no. assayed.

${ }^{\mathrm{b}}$ We excluded cases of wolf or bear and wolf or coyote. 
Table 12. Migrations to winter range and fates of elk calves from November to April captured during 2003-2005 on the northern range of Yellowstone National Park (YNP), USA.

\begin{tabular}{|c|c|c|c|c|}
\hline Birth area & $n$ & $\%$ & Winter range & Fates and comments \\
\hline Stephens Creek/Mammoth & 20 & 48 & Stephens Creek/Mammoth & $\begin{array}{l}17 \text { (85\%) survived, one died from wolf predation, } \\
\text { one from coyote predation, one was shot }\end{array}$ \\
\hline Swan Lake Flats & 8 & 19 & Stephens Creek/Mammoth & $\begin{array}{l}100 \% \text { survived, some calves made occasional trips } \\
\text { back to Swan Lake Flats }\end{array}$ \\
\hline Blacktail Deer Plateau/Tower & 8 & 19 & & \\
\hline Mount Everts and Blacktail Deer Plateau—6 & & & Mount Everts-5 & $100 \%$ survived \\
\hline Garnet Hill and Tower area-2 & & & $\begin{array}{l}\text { Northwest of YNP boundary-1 } \\
\text { Garnet Hill-1 } \\
\text { Mount Everts-1 }\end{array}$ & $\begin{array}{l}\text { Survived; Dome Mountain } \\
\text { Transmitter pull-out } \\
\text { Survived, made occasional trips back toward Tower } \\
\quad \text { area }\end{array}$ \\
\hline Lamar Valley & 6 & 14 & & \\
\hline $\begin{array}{l}\text { Mount Norris-2 } \\
\text { West of Mount Norris—4 }\end{array}$ & & & $\begin{array}{l}\text { Northeast of YNP boundary } \\
\text { Northwest of YNP boundary }\end{array}$ & $\begin{array}{l}\text { Survived; Sunlight Basin } \\
3 \text { (75\%) survived and one transmitter pull-out; } \\
\text { Dome Mountain }\end{array}$ \\
\hline
\end{tabular}

2004:719). In addition, only 2 of 33 documented deaths of radiocollared females during 2000-2004 were from winterkill (Evans et al. 2006). Thus, there was no indication that females were in poorer condition during 2003-2005 than 1987-1990, or that reproductive or calf survival rates were diminished by poor female condition.

\section{Blood Characteristics and Disease Seroprevalence}

Blood characteristic and disease-seroprevalence data are fundamental to monitoring the condition of neonates and the progression of diseases into elk herds. Such data are also useful for studies of possible "sanitation effects" (Mech 1970) wolves may have on prey populations (Barber-Meyer et al. 2007b). Our study is the first to report T4, IGF-1, GGT, and GG reference values in free-ranging neonatal elk. Our mean SUN concentration was within the ranges observed elsewhere in both free-ranging and captive neonatal elk (Hamlin and Ross 2002, International Species Information System [ISIS] 2002, Smith et al. 2006a). Our mean GGT (63 IU/L, SE $=2.7, n=134$ ) was approximately half that observed in captive elk $\leq 8$ days old (ISIS 2002; $120 \mathrm{IU} / \mathrm{L}, \mathrm{SD}=$ $84, n=9)$. Because blood characteristics can be affected by events (e.g., capture method) unrelated to condition (Franzmann 1972, Seal et al. 1972, LeResche et al. 1974, Wesson et al. 1979, Harder and Kirkpatrick 1994), the development of and adherence to standardized methods would allow for greater comparisons across studies. Although we encountered sample limitations in evaluating blood characteristics, our study nevertheless provides important reference values for future studies examining blood characteristics and survival supported by emerging research that indicates blood characteristics are useful in determining predisposition to mortality in neonatal ungulates (Smith et al. 2006a, Carstensen et al. 2008).

Antibodies in neonatal blood often reflect the mother's disease exposure rather than the neonate's (Hubbert et al. 1973). The seroprevalences of IBR, PI-3, and BVD-1 in our calves were all $\geq 25 \%$. In domestic cattle, IBR is highly contagious, results in intensely inflamed respiratory passages (Yates 1982), can lead to abortion (Smith 1997), and can become a latent infection able to be reactivated (Kahrs 1977). In elk, little is known about the epidemiology of IBR other than they can be exposed to and carry the virus, and no severe clinical effects have been detected (Kingscote et al. 1987). Although most PI-3 infections in ungulates are mild or clinically undetectable and no severe clinical effects have been demonstrated in elk, death can result when secondary infections of Pasteurella spp. cause pneumonia (Martin 1996, Frolich 2000, Storz et al. 2000). Bovine-viral-diarrhea virus type 1 causes enteritis, mucosal disease, infections, and respiratory and reproductive disorders in cattle (Baker 1995), but this apparently is not the case in elk (Tessaro et al. 1999). The epidemiology of these viruses in wild elk remains unresolved, and continued research is needed (Depner et al. 1991, Aguirre et al. 1995, Frolich 2000).

Disease seroprevalences of neonatal elk during 2003-2005 were generally similar to those of adult female elk in northern Yellowstone during 2000-2005 (Table 3; Barber-Meyer et al. 2007b) for BVD-1, BRSV, and brucellosis. However, neonates had a much higher mean IBR seroprevalence than adults and a much lower mean PI-3 seroprevalence than adults (Barber-Meyer et al. 2007b). This is surprising because we captured neonates before they joined nursery herds, and they were still relatively isolated from other calves. We expected neonatal disease seroprevalence to reflect seroprevalence of adult females because calves and adult females were captured across the same areas (Cook et al. 2004), and all calves and adults were sampled within a 6-year span (2000-2005). We suspect the difference between adult female and calf seroprevalences may be seasonal because neonates were sampled during summer, whereas adults were sampled during winter.

\section{Survival}

The over- and misapplication of information-theoretic methods to wildlife data have been criticized, including the selection of too many parameters (i.e., overfitting; Kadane and Lazar 2004), reliance on relative statistics (i.e., the method selects for a "best" model out of models available regardless of validity; Anderson and Burnham 2002, Eberhardt 2003, Guthery et al. 2005), incorrect use of AIC rather than $\mathrm{AIC}_{c}$, failure to explore nonlinearity and data dispersion (Anderson and Burnham 2002), and failure to test against independent data and to interpret biological meaning from selected models (Guthery et al. 2005). It is not likely that we over- 
Table 13. Comparisons of elk calf survival rates across North America from 1969 to 2005.

\begin{tabular}{|c|c|c|c|c|c|}
\hline Area & No. yr & Summer & Winter & Annual & Reference \\
\hline Northern Yellowstone & 3 & 0.29 & 0.90 & 0.22 & This study \\
\hline Northern Yellowstone & 4 & 0.65 & 0.72 & 0.43 & Singer et al. $1997^{\mathrm{a}}$ \\
\hline Northern Yellowstone & $7-9^{\mathrm{b}}$ & & $0.22-0.95$; males & 0.47 & Houston 1982 \\
\hline West-central Montana & 3 & 0.74 & & 0.58 & Raithel 2005 \\
\hline Southwestern Montana & 12 & & 0.95 & & Hamlin and Ross 2002 \\
\hline Southwestern Montana & 1 & 0.48 & & & Hamlin 2006 \\
\hline Northwestern Wyoming & 3 & 0.84 & 0.84 & 0.58 & Smith and Anderson 1998 \\
\hline North-central Idaho & 3 & 0.32 & & & Schlegel 1976 \\
\hline North-central Idaho & $8.5^{\mathrm{c}}$ & $0.00-0.84$ & & $0.06-0.83$ & Zager et al. 2005 \\
\hline Southeastern Washington & 5 & 0.58 & & $0.06-0.40$ & Myers et al. 1996 \\
\hline Michigan & 5 & 0.90 & 0.97 & 0.87 & Bender et al. 2002 \\
\hline
\end{tabular}

\footnotetext{
${ }^{a}$ Data are from 1987 to 1990.

b Winter survival data are from 1970 to 1978 (Houston 1982:49). Annual survival data are from 1969 to 1975 (Houston 1982:241).

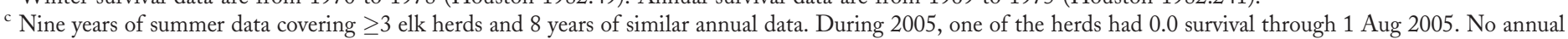
data for 2005 were published on any of the herds.
}

fit our data because the selected survival models were relatively simple and generally included variables documented as important in other juvenile elk survival studies (Dekker et al. 1995, Smith and Anderson 1996, Raithel 2005). Also, we found that all of the selected models were candidate models even under simulated overdispersion ( $\hat{c}=3.0$, Devries et al. 2003) and our methods accounted for many user-induced problems except for evaluating the selected models against independent or held-back data. We used all our data because our sample was small and little was known about the influence of physiological and pathological variables on elk calf survival in a predator-rich environment.

Annual survival (0.22) of northern Yellowstone calf elk during 2003-2005 was lower than most survival rates found in other elk studies (Table 13), probably because Yellowstone contains more predator species than do most other areas. The difference in annual survival was largely due to lower summer survival (0.29) compared with other juvenile elk studies across North America and northern Yellowstone elk during 1987-1990. Summer survival in our study (0.29) was generally lower than, but within the range of, means observed for other juvenile elk studies across North America (Table 13). Survival during summer was lowest during the first 2 weeks (0.65) after radiotagging (approx. first 2 weeks of life). Similarly, during 1987-1990, the majority of summer (birth-31 Aug) mortality of northern Yellowstone elk occurred at 3-10 days of age (Singer et al. 1997), and in northcentral Idaho $80 \%$ of the mortality occurred by 14 June (approx. 2 weeks of age; Schlegel 1976). During the first 2 weeks, relatively defenseless calves hide to avoid predation (Lent 1974), and their survival may depend upon the mother's ability to hide her calf and on the propensity of the calf to remain hidden (Geist 2002). If the calf is detected by a predator during the calf's first week, the calf will likely be killed unless the mother (alone or with a group) can defend the calf (Kruuk 1964, Bergerud 1974, Estes 1976, Estes and Estes 1979, Wissel and Brandl 1988) and move it elsewhere. During week 2, calves tend to run rather than hide when in danger, but they are still prone to predation because their running ability is not yet well developed. During weeks 3-6, calves detected by predators are less vulnerable because they have joined nursery herds (Altmann 1952), and they sometimes can escape predators depending upon their running and grouping ability when tested (Geist 2002).
As a result of low summer survival, our sample was temporally biased toward summer (at start of summer $n=151$, whereas in winter $n=42$ ); thus, our results may not completely reflect winter survival and mortality typical throughout the northern range. Due to calf migrations and higher mortality in areas with higher summer predator density (e.g., Lamar Valley and Swan Lake Flats; K. Gunther and D. Smith, unpublished data), our sample was spatially biased during winter toward the lower elevations of the northern range (i.e., primarily Stephens Creek/Mammoth area). However, this spatial bias may not be significant because that area is where most northern Yellowstone calves winter (Coughenour and Singer 1996, Singer et al. 1997). Average winter survival in our study (0.90) was high compared with summer, within the range observed in other studies (Table 13), and similar to that observed in YNP during 1989 and 1990 (0.92 and 0.94, respectively) after the 1988 drought and wildfires (Singer et al. 1997).

\section{Factors Affecting Survival}

Year was not important in our summer, winter, or annual survival models. The relative lack of variability in spring and summer weather and the mild-to-average winters during 2003-2005 likely contributed to this finding. Annual calf survival before wolf restoration $(1987=0.48,1988=0.14,1989=0.62$, and $1990=$ $0.47)$ varied negatively with increased winter severity, increased winter precipitation, and the fires of 1988 (Singer et al. 1997). During the mild winter of 1998, almost half the northern Yellowstone elk killed by wolves in March were calves, but during the previous severe winter only 2 of the 34 elk killed by wolves were calves (Mech et al. 2001). However, overwinter calf survival varied inversely with the severity of the snowpack for nonmigratory elk in west-central YNP during 1991-1998 (Garrott et al. 2003). Also, survival of female calves tagged in northwestern Wyoming (near Jackson) was correlated with summer temperature and inversely correlated with November precipitation (Sauer and Boyce 1983).

Because calf birth mass is in part determined by the condition of the adult female (Thorne et al. 1976, Clutton-Brock et al. 1982, Singer et al. 1997, Cook 2000) we expected that 2005 summer birth masses would be higher because May 2005 was wetter than 2002-2004 (National Climate Data Center 2006a), which may 
have resulted in higher quality forage for adult females. However, the difference in birth masses was not retained in our summer survival model. Similarly, a juvenile elk study on the National Elk Refuge near Jackson, Wyoming, concluded that birth mass was not important in summer survival (Smith and Anderson 1996). Predation pressure during our study may have been so high that the importance of calving area (i.e., varying concentrations of predators) overwhelmed the contribution of birth mass. Or, although there was more total precipitation during May 2005 compared with May 2003 and 2004, perhaps the importance of birth mass was diminished because mean spring precipitation during 2005 (Mar-May) was not statistically different $(P=0.91$, $F_{3,8}=0.17$ ) from that during 2002-2004 (National Climate Data Center 2006a). Also, the monthly mean temperature reported during May $2005\left(45.1^{\circ} \mathrm{C}\right)$ was similar to that of the other years (May 2003, $45.6^{\circ} \mathrm{C}$; May 2004, $44.4^{\circ} \mathrm{C}$; National Climate Data Center 2006b). Possibly with increased weather variability, birth mass and year may play a greater role in survival because both birth mass and winter severity were significant in YNP elk calf survival from 1987 to 1990 (Singer et al. 1997). Birth mass may also play a more important role in situations where the main predators are not bears, which are not as likely to prey on neonates in poor condition as are wolves due to differences in hunting techniques (although poor condition may still play a role; see Discussion, Compensatory and Additive Mortality). Furthermore, although calf birth masses in our study did not indicate malnutrition, condition well after birth also likely has an important influence on survival (Zager et al. 2005).

Calving area was important in summer and annual survival, with the highest survival for calves captured in the Stephens Creek/ Mammoth area and the lowest for calves captured in the Lamar Valley area (Table 6). Higher survival in the Stephens Creek/ Mammoth area may be partially explained by the human residential area in Mammoth where elk congregate but predators are less likely to occur during spring and summer (K. Gunther and D. Smith, unpublished data). However, calves born in the undeveloped portion of the Stephens Creek/Mammoth area also had much lower probabilities of being killed by a predator likely due to the comparatively lower predator densities throughout this area during spring and summer (K. Gunther and D. Smith, unpublished data). Lower survival in the Swan Lake Flats and Lamar Valley calving areas is likely a function of a high density of bears that historically have congregated in these areas during calving season (Grimm 1947, Reynolds 1950), well-established resident wolf packs (Smith et al. 2005), and the absence of substantial human residential areas that might serve as refuges for elk. In Jasper National Park, Alberta, elk calf survival was also higher in areas of presumably lower predator (wolf) density (Dekker et al. 1995). The density of calves and adult female elk in the Blacktail Deer Plateau/Tower area has been historically low compared with the other main calving areas. This lower density may explain the intermediate survival we documented in this area. It may not be optimal for predators to search for elk calves (small prey item relative to $\geq 1$-yr-old elk) when their density is below a particular level relative to adult elk (Stephens and Krebs 1986). Calving area was likely not important in winter survival because overall mortality was summer-biased and most surviving radio- tagged calves migrated to the northwestern areas of the park to winter (Table 12).

Although predation during the 1-2-week hiding phase may seem to be nonselective, predators during this phase may select neonates in poor condition expressed through neonatal behavior. Neonates in poor condition during the hiding phase may be more likely to cry out for additional feedings from their mother due to their malnutrition, which may expose the hiding neonate to predators. Also, neonates in poor condition may be less apt to follow their mothers to new hiding locations, resulting in stronger scent trails created by the mother traveling to the neonate's location, again increasing the predator's ability to detect the neonate. A study in which predation was the major mortality source of white-tailed deer in Minnesota lends support to the theory that neonates in the hiding phase may be selected based on condition. That study found serum urea nitrogen and triglycerides were lower and mean potassium concentration higher in neonates that survived to 1 week (Carstensen et al. 2008). Similarly, Wyoming elk calves with lower levels of blood urea nitrogen survived better where predation was the main mortality source (Smith et al. 2006a).

Our selected summer survival models included bdtdev and GG. The majority of northern Yellowstone elk calved during 21 May12 June, which was within the range of means reported for other populations of free-ranging elk (Rust 1946, Johnson 1951, Flook 1970, Schlegel 1976, Smith et al. 1997, Raithel 2005). Calves born closest to the median birth date survived better during our study, possibly due to a dilution effect (Darling 1938, Pulliam and Caraco 1984, Rutberg 1987), confusion effect (Hamilton 1971), and/or increased defense afforded by numerous vigilant adult females (Kruuk 1964, Bergerud 1974, Estes 1976, Estes and Estes 1979, Wissel and Brandl 1988). We expect that predation was a driving force behind calving synchrony because it was the main source of mortality in our study (and likely reflects evolutionary history before the extermination of wolves in Yellowstone). Calves born significantly postpeak (e.g., Jul) likely do not have increased survival because predators may still be abundant on calving ranges, predator search images have been honed, and neither the dilution nor confusion effects are as effective as during the peak (Testa 2002).

Elk calves with higher GG levels had higher survival during our study, similar to white-tailed deer fawns in Oklahoma during 1990-1992 (Ditchkoff et al. 2001) but in contrast to Wyoming elk calves studied during 1997-1999 (Smith et al. 2006a). Lower GG may indicate poorer condition and have been associated with a variety of diseases and neonatal ungulate mortality (Findlay 1973, Harker 1974, Logan and Gibson 1975, McGuire et al. 1976, Vihan 1988). Because we did not consider interactions in our survival model, the importance of GG may be related to older males having better survival than younger females because we were only able to test these covariates as main effects due to sample limitations. However, it is interesting to note that calves with the lowest mean GG were killed by wolves, followed by those that died from nonpredator sources (Table 11).

Additional factors that may predispose calves to mortality may have been missed due to small samples because calving area was used as a blocking variable in the survival model (e.g., Blacktail 
Table 14. Comparisons of summer predation rates (calves killed/total sample) among published studies of juvenile elk across North America.

\begin{tabular}{lccll}
\hline \multicolumn{1}{c}{ Area } & No. yr & Predation rate (\%) & \multicolumn{1}{c}{ Period } & \multicolumn{1}{c}{ Reference } \\
\hline Northern Yellowstone & 3 & 63 & Capture to 31 Aug of uncensored calves & This study \\
Northern Yellowstone & 4 & 22 & Capture to 31 Aug & Singer et al. 1997 \\
West-central Montana & 3 & 17 & Capture to 31 Aug & Raithel 2005 \\
Southwestern Montana & 12 & 17 & Capture to 31 Aug & Hamlin and Ross 2002 \\
Northwestern Wyoming & 3 & 10 & Capture to 15 Jul & Schlegel 1976 Anderson 1996 \\
North-central Idaho & 3 & 64 & Capture to 31 Oct of uncensored calves & Zager et al. 2005 \\
North-central Idaho & 1 & 29 & Capture to 1 Aug & \\
\hline
\end{tabular}

${ }^{a}$ Data are from 1987 to 1990.

Deer Plateau/Tower, $n=25)$. Samples of 30-35 in each calving area during each period when covariates are evaluated are ideal. If the research objective were to evaluate predisposing characteristics during winter, either significantly more calves would need to be captured at the beginning of the study or additional captures would need to occur in the autumn. Given the probability of summer survival estimated in our study (0.29), we would have needed to capture approximately 121 calves each year (362 total) to have about 35 calves survive to the start of each winter. Alternatively, we could have captured approximately 23 more calves each autumn (69 total) to increase the sample at the start of each winter.

\section{Cause-Specific Mortality}

Predators killed $65 \%$ of captured calves and accounted for $94 \%$ (98 of 104) of all confirmed deaths. Almost all of this predation (95 of 98) occurred before November. In contrast, during 1987-1990 predators killed 23\% $(n=29)$ of all captured calves $(n=127)$ and accounted for $45 \%(n=29)$ of all deaths $(n=65$; Singer et al. 1997). The summer predation rate during 2003-2005 was $63 \%$ (92 of 145) of uncensored calves by 31 August, a much higher rate than reported by most other studies (Table 14). This recent trend of greater predation in the northern Yellowstone elk herd is the most likely contributor to low elk calf recruitment.

There were only 4 confirmed deaths during the winters of 20032006, none of which were due to malnutrition (3 predators and 1 hunter). In contrast, 15 of 26 winter mortalities during 1987-1990 were due to malnutrition (Singer et al. 1997). We expected fewer winter malnutrition deaths during 2003-2006 than 1987-1990 because elk densities were lower (counts averaged 9,032 during 2003-2005 and 15,435 during 1987-1990; Singer et al. 1997, White and Garrott 2005a) and winters were milder (Singer et al. 1997). However, the high survival we observed during winter may also have been due to calves originally captured in the Lamar Valley area migrating elsewhere during winter (Table 12). The 6 calves we captured in the Lamar Valley area that still had functioning transmitters by November of their birth year migrated 40-60 km northwest to the Dome Mountain area or northeast to the Sunlight Basin area. All of these calves survived through April, even though wolves were present in both areas. Dome Mountain and Sunlight basin had lower wolf presence (6-15 wolves) than the 19-34 wolves that used portions of the Lamar Valley during 2003-2005 (U.S. Fish and Wildlife Service et al. 2005).

Bears killed the most elk calves. Numerous studies have documented bears (sympatric with wolves) are efficient neonatal ungulate predators in the Greater Yellowstone Ecosystem (Gunther and Renkin 1990, Smith and Anderson 1996, Singer et al. 1997, Clark et al. 1999, Smith et al. 2006a), Alaska (Whitten et al. 1992, Adams et al. 1995, Bertram and Vivion 2002, Valkenburg et al. 2004, Jenkins and Barten 2005), Minnesota (Kunkel and Mech 1994, Carstensen et al. 2008), and Canada (Hamer and Herrero 1991, Dekker et al. 1995) and elsewhere where wolves are not present (Pojar and Bowden 2004, Vreeland et al. 2004). Black bears caused $50 \%$ of confirmed deaths by 15 July on the National Elk Refuge (Smith and Anderson 1996) and $74 \%$ of the total mortality through October in northcentral Idaho (Schlegel 1976). Although it is not surprising that bears were significant predators in our study, it is interesting to note their increased importance since the previous YNP elk calf study. During 1987-1990 (Singer et al. 1997), mortality by bears accounted for $12 \%$ of captured calves, compared with $40 \%$ during our study $\left(\chi_{1}^{2}=16.20, P<0.01\right)$.

Since the previous study, grizzly bear abundance has increased almost 3-fold (Haroldson et al. 1998, Haroldson and Frey 2005; Figs. 5, 6). The minimum grizzly bear estimate in the Greater Yellowstone Ecosystem increased from 135 in 1983 to 431 in 2005 (Schwartz et al. 2006), which equates to 70-92 grizzlies on the northern range during summer (K. Gunther, unpublished data). Similarly, the number of unduplicated sightings of grizzly bears with cubs increased from 13 in 1987 to 31 in 2005 (Haroldson 2006). Abundant black bears inhabit the northern range during autumn and summer in unknown numbers $(\mathrm{K}$. Gunther, unpublished data). The greater (approx. 3-fold) proportion of bear-killed calves in our study likely reflects the increase in bear abundance (approx. 3-fold) rather than a change in bear feeding behavior, although it is possible that less winterkilled carcasses are available for bears emerging from their dens each spring due to wolf consumption; therefore, bears may need to

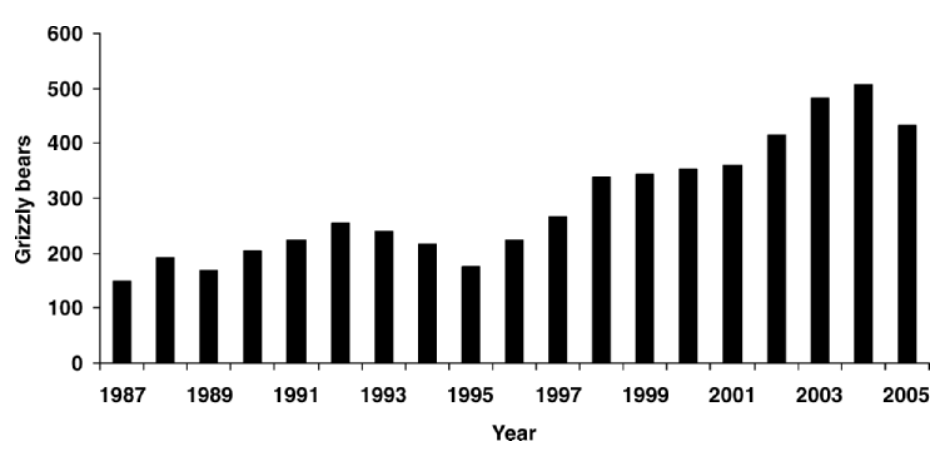

Figure 5. Grizzly bear minimum population estimates in the Greater Yellowstone Area, USA, 1987-2005. Data are from Haroldson et al. (1998), Haroldson and Frey (2005), and Schwartz et al. (2006). 


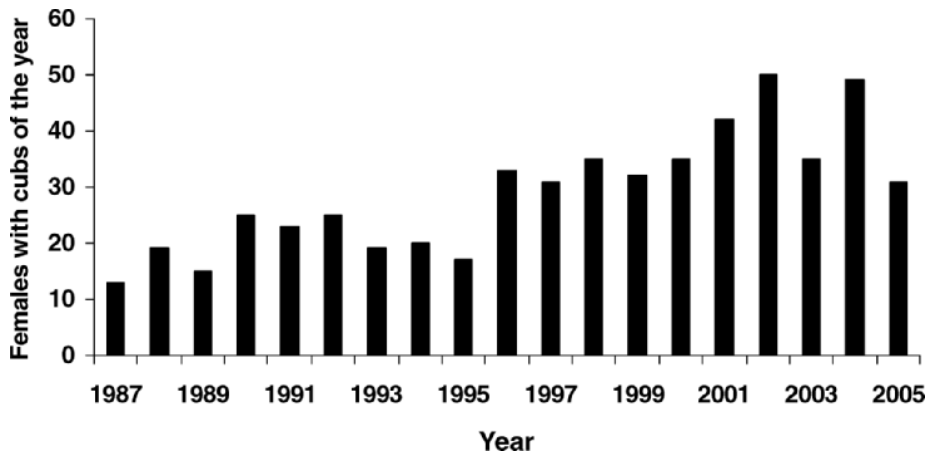

Figure 6. Grizzly bear unduplicated sightings of females with cubs of the year in the Greater Yellowstone Area, USA, 1987-2005. Data are from Haroldson et al. (1998), Haroldson and Frey (2005), and Haroldson (2006).

depend more on other food sources such as elk calves (Smith and Anderson 1996, Mattson 1997). Additionally, bear predation on northern Yellowstone elk calves may vary in response to the availability of whitebark pine nuts (Pinus albicaulis, a masting species) remaining from the previous summer and autumn because bears feed on these nuts after emerging from their dens each spring (Mattson et al. 1991, Mattson 1997, Felicetti et al. 2003).

Using the cause-specific mortality rates we observed and estimated predator abundance (Figs. 5-7), we estimated that bears killed more elk calves per year (2,544) during 2003-2005 on the northern range of Yellowstone than wolves, coyotes, and cougars combined (1,252; Fig. 8). We also estimated that grizzly bears killed more elk calves/individual predator (19) than wolves, coyotes, and cougars combined (16; Fig. 9). These estimates are necessarily biased due to high summer mortality (i.e., small winter sample) and migration of surviving, tagged calves to winter ranges with lower wolf densities. However, even if wolves had killed all the survivors in our study $(n=36$, potential total wolf kills $=51-$ 54 ), bears would have still killed more elk calves overall from our beginning sample $(n=60-62)$.

Coyotes were secondarily important predators in our study, along with wolves. Coyotes remain abundant in the study area, although their numbers decreased for a few years due to killing by wolves (Crabtree and Sheldon 1999), which may explain the slight decrease in coyote predation; 7\% of captured calves during our study compared with 9\% during 1987-1990 (Singer et al. 1997).

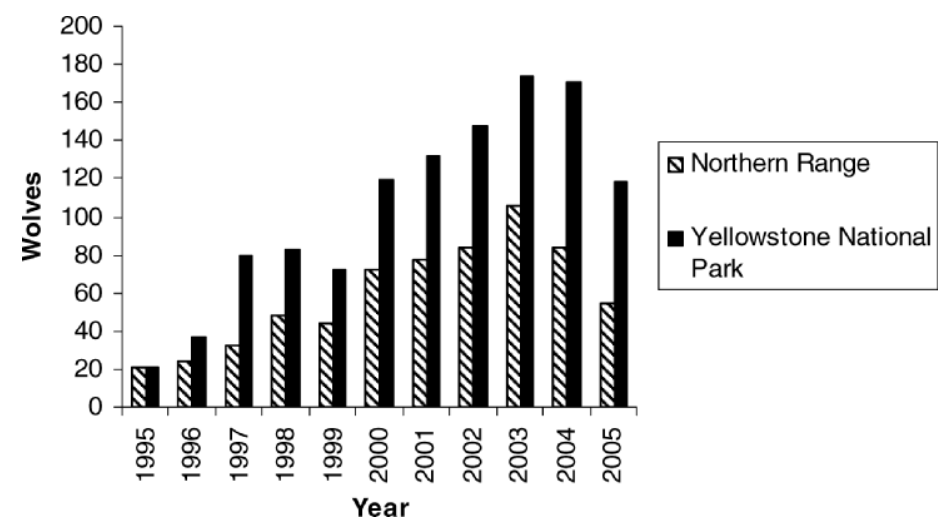

Figure 7. Wolf population in Yellowstone National Park, 1995-2005. Data are from Smith et al. (2006b) and U.S. Fish and Wildlife Service et al. (2005).

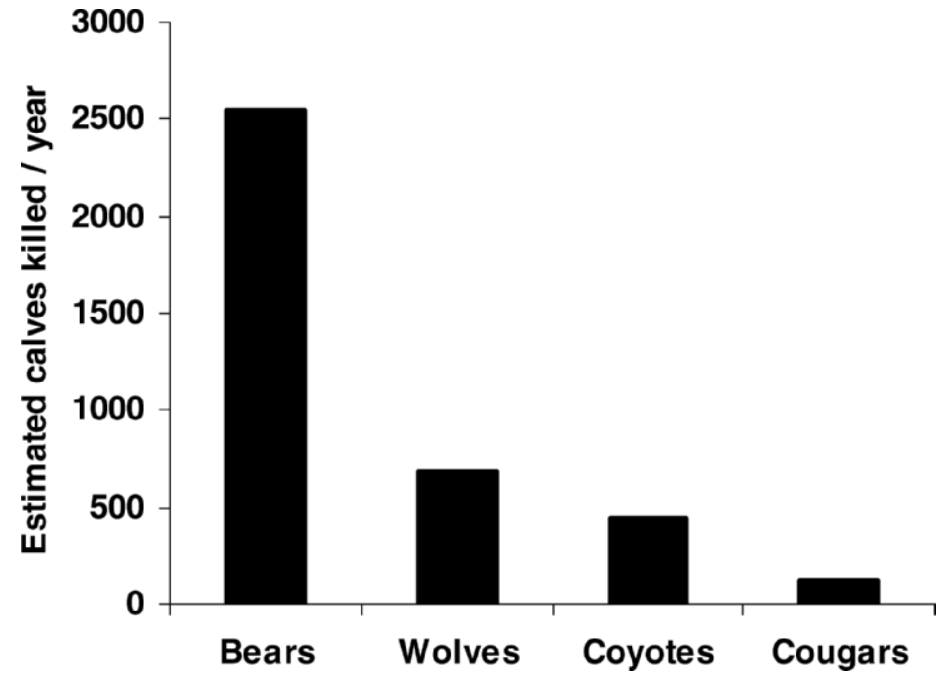

Figure 8. Estimated number of northern-range Yellowstone elk calves killed by predator source/year in Yellowstone National Park, USA, during 2003-2005 based on the cause-specific mortality rates (no. killed/151 calves captured). We estimated the annual calf crop per year $(6,298)$ by multiplying 12,000 elk (approx. mean elk abundance determined from counts corrected for sightability; Coughenour and Singer 1996, Eberdardt et al. 2007) by 64\% females (Houston 1982) and by $82 \%$ pregnancy (Cook et al. 2004).

This slight decrease was not significant $\left(\chi_{1}^{2}=0.35, P=0.55\right)$. It is interesting that wolf predation accounted for only slightly more mortalities than coyote predation (14-17\% of all confirmed deaths vs. $10-11 \%$, respectively), although these findings may be somewhat biased by high summer mortality.

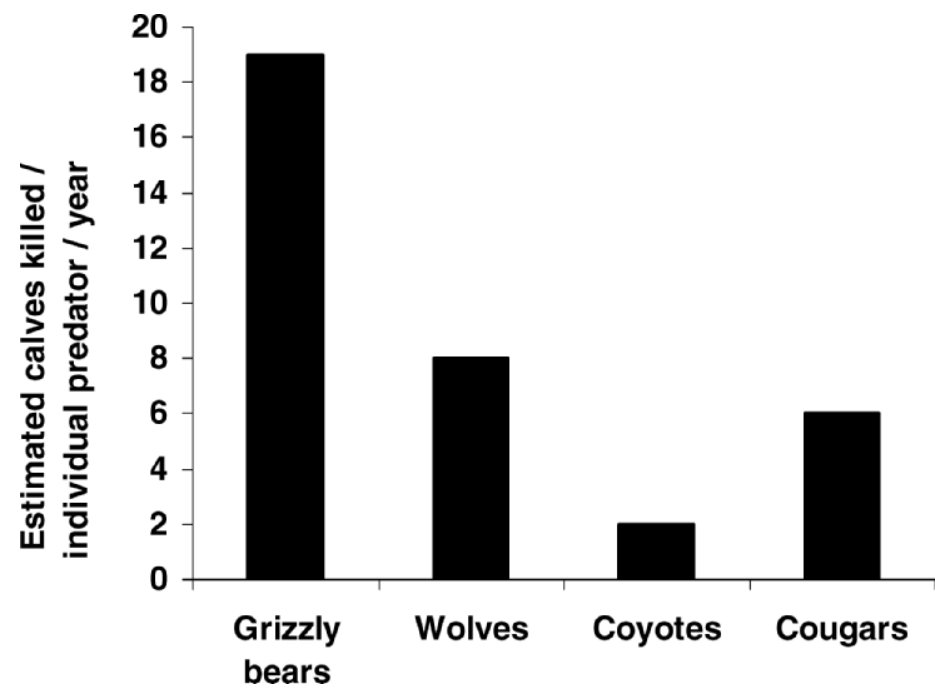

Figure 9. Estimated number of northern-range Yellowstone elk calves killed by individual predators/year during 2003-2005 based on the cause-specific mortality rates (no. killed / 151 calves captured). We estimated the annual calf crop per year $(6,298)$ by multiplying 12,000 elk (approx. mean elk abundance determined from counts corrected for sightability; Coughenour and Singer 1996, Eberhardt et al. 2007) by $64 \%$ females (Houston 1982) and by $82 \%$ pregnancy (Cook et al. 2004). We assumed there were 81 grizzly bears (approx. 70-92; Haroldson and Frey 2005; K. Gunther, unpublished data), 84 wolves (106, 89, and 57 wolves during Nov-Dec 2003, 2004, and 2005, respectively), 225 coyotes (Crabtree and Sheldon 1999), and 20 cougars (Ruth 2004) on the northern range during our study. Because only grizzly bear abundance was estimated, we could not approximate this for black bears or all bears. 
In addition to wolf restoration to YNP (Fig. 7) and increasing bear abundance (Figs. 5, 6), cougar densities in the northwestern portion of the northern range increased (Murphy 1998, Ruth 2004). However, our rate of calf kill by cougars (2\%) was not statistically different from that found in the previous study $(1 \%$, Singer et al. 1997; $\left.\chi^{2}{ }_{1}=0.68, P=0.41\right)$. Because the mean age of calves cougars killed was 107 days, it seems that cougars do not specialize on neonates. This is probably due to their hunting technique (Kruuk 1972, Schaller 1972), as stalkers that surprise their prey and opportunistically attack (Hirst 1965, Schaller 1967, Hornocker 1970).

\section{Compensatory and Additive Mortality}

During 1987-1990, counts of northern Yellowstone elk ranged from 10,265 to 18,913 and averaged 15,042 , which is likely a 20 $40 \%$ underestimate of the actual elk population based on sightability during survey conditions (Coughenour and Singer 1996). During 2003-2005, elk counts (also not corrected for sightability) averaged 9,032 (range $=8,335-9,545$; White and Garrott 2005a) representing an approximate $40 \%$ decline between the prewolf restoration calf study (Singer et al. 1997) and our study. Despite this substantial decrease in elk density, annual survival of tagged elk calves was significantly lower during 20032005 (0.22) than 1987-1990 (0.43). This decreased survival at lower density was due primarily to a significant increase in summer predation rates during 2003-2005 (63\%) compared with 19871990 (22\%). During our study, no calves surviving to winter died of malnutrition or disease. By comparison, $15 \%$ of summer mortality (6 of 39 deaths) and $65 \%$ of winter mortality (17 of 26 deaths) were attributed to starvation, disease, and accidents during 1987-1990 (Singer et al. 1997). Based on these findings, we suggest mortality due to predation had a significant additive component during the lower-density phase of the population in 2003-2005, similar to the findings of other researchers on moose in Alaska, USA, and Canada (Gasaway et al. 1983, 1992; Ballard et al. 1991; Messier 1994; Hayes et al. 2003). Approximately 171 wolves resided in YNP during 2004, and during winters of November 1995-March 2004, elk calves accounted for 38\% $(n=$ 389 of 1,024) of documented wolf-killed elk on the northern range (Smith et al. 2005). Thus, wolves could limit elk recruitment if much of this predation was additive to other mortality.

Our nonpredation mortality rate was much lower $(n=5$ of 104 deaths) than during 1987-1990, which indicates some predation mortality was likely compensatory. Our finding of partial compensatory mortality was expected because, even at lower ungulate densities, vulnerable prey are still available for compensation. For examples, juveniles born to first-time mothers tend to survive less (Ozoga and Verme 1986, Mech and McRoberts 1990), and, even where no predators exist, $7-21 \%$ of juvenile ungulates die before hunting season (Loudon 1985, Linnell et al. 1995, Sæther and Andersen 1996, Andersen and Linnell 1998). Therefore, 7-21\% of our captured calves (11 to 32 deaths of 151 calves) might have died from nonpredation deaths (e.g., disease, starvation, exposure) in the absence of predation. Because we only observed 5 nonpredation deaths, possibly another 27 calves $(32-5$ $=27,18 \%$ of all calves) might have died from starvation, disease, or accidents had they not been killed by predators. Using this measure, $28 \%$ of the total predation mortality ( 27 of 98 predation deaths) and $26 \%$ of all mortality (27 of 104 total deaths) might have been compensatory with starvation, disease, or accidents.

In a review of studies with predators, the proportion of nonpredation mortality of juvenile ungulates ranged from zero to $87 \%$ (Linnell et al. 1995). Elk studies have shown similar variation (Schlegel 1976, Bear 1989, Smith and Anderson 1996, Singer et al. 1997, Hamlin and Ross 2002). Thus, $\geq 28 \%$ (27 of 98 predation deaths) and possibly as much as $87 \%$ (85 of 98 predation deaths) of the total mortality caused by predation (94\%, 98 of 104 total deaths) might have compensated for deaths that would otherwise have resulted from starvation/disease. However, these comparisons do not account for differences in predator densities, prey densities, or both across studies or potential synergistic effects of multiple predators (Gasaway et al. 1992; Ballard and Van Ballenberghe 1997; Crête 1998, 1999). As a result, 87\% compensatory mortality is likely too high an estimate for our study because YNP supports a larger predator suite than other areas in North America; therefore, there are less predisposed animals available to each predator on average for compensation because other predators are likely compensating for some deaths as well (assuming nonwolf predation can also be compensatory). Although predation must have numerically compensated for some deaths, temporally, predation probably resulted in earlier deaths because juvenile condition is likely a continuum, with the poorest dying first and others during winter or spring.

Whether primarily bears, wolves, or coyotes compensate for starvation- and disease-related mortality in YNP may depend on their hunting methods. Wolves, and coyotes to a lesser extent, are coursers eliciting flight followed by herd sorting (Estes and Goddard 1967), which generally leads to capture of prey in poorer condition (Mech 1970, Kruuk 1972, Mech et al. 1998, Mech and Peterson 2003, Smith et al. 2004). In contrast, bears search in grid-like patterns during May and June for hiding neonates (Gunther and Renkin 1990), which are highly vulnerable once detected (although whether or not neonates are detected partially depends on their behavior that may be determined in part by their condition). Therefore, wolf predation, followed by coyote predation, more likely compensates for starvation and disease than does bear predation. However, due to temporal differences in predation pressures, this distinction may not be important. Bear predation was so significant and early in our study that it may preclude compensating by the later (on average) wolf or coyote predation.

Also, there is always some winterkill. As a result, the potential exists for compensatory predation in the northern Yellowstone elk population because it inhabits a mountainous area with severe environmental fluctuations (Houston 1982). Thus, the lack of winter malnutrition mortality in our study compared with the 58\% during the prewolf study (Singer et al. 1997) indicates that partial compensation may be occurring despite the increased predation we documented. The extreme 8-year drought (1998-2005, National Climate Data Center 2005) may have temporarily decreased the ecological carrying capacity for elk on the northern winter range, even though there were 40\% fewer elk during 2003-2005 than 1987-1990. However, this potential drought effect was counterbalanced somewhat by a series of relatively mild winters during 
2003-2005, during which carcass surveys indicate winterkill was insignificant (about 3 carcasses/survey) compared with 1990-1996 (4-78 carcasses/survey) and during the severe winter of 1997 (534 carcasses; Lemke 2005). Unfortunately, these standardized carcass surveys were not conducted during the moderate winter of 20052006. However, field observations indicate winterkill was somewhat higher than during 1990-1996 (D. Smith and K. Gunther, unpublished data).

\section{Modeling Implications}

Models assessing weather, hunting, and wolf predation to explain the elk decline after wolf restoration (White et al. 2003, Vucetich et al. 2005, Varley and Boyce 2006) underestimate the role of bear predation or incorrectly assign its effects to another mortality source. Our results and those of other studies cited herein indicate that among predators, bears can substantially influence ungulate recruitment. Research conducted on caribou (Rangifer tarandus) and moose calf mortality in Alaska also demonstrated that bear predation was predominant early and declined with calf age, whereas wolf predation peaked later (Gasaway et al. 1992, Adams et al. 1995). Although we did not document increased wolf predation during winter, this likely resulted from high summer mortality that reduced our sample to primarily calves living in areas of fewer predators (e.g., fewer bears and wolves during spring and summer in the Stephens Creek/Mammoth area than Swan Lake Flats or Lamar Valley areas; K. Gunther and D. Smith, unpublished data). Because our sample was temporally biased towards summer and spatially biased during winter toward the northwestern part of the northern range, it may not have included sources of winter mortality that are typical across the northern range. Although calves represented $12-25 \%$ of winter wolf-killed elk from December and March during 2004-2005 across the northern range (Smith et al. 2005, 2006b), it is important to note that the area intensively studied did not include the northwestern portion (i.e., Stephens Creek/Mammoth area) where the majority of our calves wintered. If the Stephens Creek/Mammoth area had been included, the proportion of calves killed by wolves may have been much less because, although wolves inhabited this area, the apparent overwinter calf mortality rate in this area was lower than that observed in the area intensively researched by the Yellowstone wolf winter study.

Another problem our study exposes in models attempting to describe the decline in northern Yellowstone elk is that most are not spatially explicit in terms of the various calving grounds across the northern range (White et al. 2003, Vucetich et al. 2005, Varley and Boyce 2006). Calves born in the Stephens Creek/Mammoth and Mount Everts/Blacktail Deer Plateau/Tower areas were much less likely to be killed by a bear during their first year $(21 \%$ and $25 \%$, respectively) than calves born in Swan Lake Flats (68\%) and Lamar Valley (58-60\%). Our results show the importance of accounting for the unique mortality rates within each calving area by using estimates generated from a northern range-wide sample.

Accounting for the varying mortality rates of calf elk may become increasingly important as the northern herd shifts in geographic abundance (White and Garrott 2005a). If elk shift calving grounds from the Lamar Valley or Swan Lake Flats where bears historically congregate (Grimm 1947, Reynolds 1950) to the Stephens Creek/Mammoth or Blacktail Deer Plateau areas where
Table 15. Proportions of elk calf captures in different calving areas across the northern range of Yellowstone National Park, USA, 1987-1989 and 2003-2005.

\begin{tabular}{|c|c|c|c|c|}
\hline \multirow[b]{2}{*}{ Calving area } & \multicolumn{2}{|c|}{$1987-1989^{a}$} & \multicolumn{2}{|c|}{ 2003-2005 } \\
\hline & $n$ & $\%$ & $n$ & $\%$ \\
\hline Stephens Creek/Mammoth & 1 & 1.0 & 39 & 25.8 \\
\hline Swan Lake Flats & 51 & 51.0 & 39 & 25.8 \\
\hline Mount Everts/Blacktail Deer Plateau/Tower & 2 & 2.0 & 30 & 19.9 \\
\hline Buffalo Plateau/Northeast Little America ${ }^{\mathrm{b}}$ & 10 & 10.0 & 1 & 0.7 \\
\hline Lamar Valley/Mount Norris ${ }^{\mathrm{b}}$ & 29 & 29.0 & 42 & 27.8 \\
\hline Cache Calfee Ridge $^{c}$ & 7 & 7.0 & 0 & 0.0 \\
\hline Total captures & 100 & & 151 & \\
\hline
\end{tabular}

${ }^{a}$ F. Singer (deceased), United States Geological Survey, unpublished data; no data for 1990.

${ }^{\mathrm{b}}$ For purposes of comparing to Singer et al. (1997), one calf we captured in the Buffalo Plateau/Northeast Little America area is separated from our Lamar Valley captures.

${ }^{\mathrm{c}}$ Calf captures were not conducted during 2003-2005 in the Cache Calfee Ridge area.

there are fewer bears, calf recruitment may increase. However, bears may eventually shift to these alternate calving grounds unless bears are congregating in the historic areas (Swan Lake Flats and Lamar Valley) primarily for vegetation, which coincidentally may be why elk use these areas (Schlegel 1976). Comparisons of the locations of our neonate captures to those from 1987-1989 indicate that this elk shift may be occurring (Table 15). However, human harvests may become more important because elk in the areas of lower bear density (especially Stephens Creek/Mammoth) are more likely to be exposed to hunting than those remaining in the interior of the park (Lemke 2003). Furthermore, dissimilar mortality rates for adult elk at varying elevations and hunting pressures across the northern range have been documented (Lemke 2003, Wright 2003), along with a varying age distribution of female elk (i.e., older female elk in the northeast and younger in the northwest; Houston 1982, Coughenour and Singer 1996, Barmore 2003, Cook et al. 2004). Varying survival based on both calf and adult elk spatial relationships within the northern range should be considered.

\section{Recruitment Rate Comparisons}

We estimated mean annual elk calf survival at $0.22(95 \% \mathrm{CI}=$ $0.15-0.29$ ). We used our survival rate and its $95 \%$ confidence interval along with an estimated $82 \%$ pregnancy rate (Cook et al. 2004), to estimate a mean calf:adult female ratio of $18: 100(95 \%$ confidence interval $=12-24: 100)$. However, our estimate of winter survival was biased due to high summer mortality and migration of surviving, tagged calves to areas with lower wolf densities. The majority (93\%; 97 of 104) of mortality in our study occurred before September, but 12-25\% of documented wolf kills of elk in the Blacktail Deer Plateau to Lamar Valley area during December and March of winters 2004 and 2005 were calves (Smith et al. 2005, 2006b). Also, cougars selectively kill elk calves during this period (Ruth 2004). Thus, our annual estimates of survival are likely biased somewhat high. Despite this bias, our mean calf:adult female estimate was similar to the mean ratio of 16 calves:100 adult females (both ratios include yearlings as adults) observed by the Northern Yellowstone Cooperative Wildlife Working Group during late-winter (Feb-Mar) aerial surveys during 2004 (12:100, $95 \% \mathrm{CI}=11-14: 100), 2005$ (13:100, 95\% CI $=12-14: 100)$, and 
2006 (24:100, 95\% CI =22-26:100; 95\% CI were calculated using odds ratios without replacement and an estimate of the population size of 10,000-12,000 elk [i.e., PopComp program, Kim Keating, United States Geological Survey-Northern Rocky Mountain Science Center, Bozeman, MT]), and the ratio predicted from a deterministic WOLF6 model (Varley and Boyce 2006). Our estimated ratio was lower than those predicted for 10,12, and 14 years postwolf restoration (26, 36, 34:100, respectively; Mack and Singer 1993a) and than the mean observed from 1967-1968 to 1989-1990 ( $\bar{x}=33.5: 100, \mathrm{SD}=9.2$, range $=17-48: 100$; Mack and Singer 1993b). Also, our mean calf:adult female ratio was similar to that in Jasper National Park, Alberta, Canada, when elk calved near wolf denning sites (18-19:100; Dekker et al. 1995).

\section{Expectations for the Northern Yellowstone Elk Population}

In some situations, wolf predation seems to limit ungulate numbers in North America (Ballard et al. 1987, 1991; Gasaway et al. 1992; Hayes et al. 2003; Mech and Peterson 2003), but there is considerable debate regarding whether wolves show a densitydependent response that allows them to regulate ungulate numbers at suppressed equilibrium densities. Wolves were reported to regulate moose at low densities (Messier 1994, Hayes and Harestad 2000). However, others contend the combined predation of bears and wolves was necessary to regulate moose at a lower equilibrium (Gasaway et al. 1992; Ballard and Van Ballenberghe 1997; Crête 1998, 1999). Also, Nelson and Mech (2006) reported wintering white-tailed deer have not recolonized a $3,000-\mathrm{km}^{2}$ area in northeastern Minnesota 30 years after they were decimated by a combination of severe winters and wolves, likely due to wolf persistence in the area supported by moose predation. Predation by bears and coyotes limited, but did not regulate, the northern Yellowstone elk population during 19871990 (Singer et al. 1997). Depending on the population growth of bears in YNP, increased calf mortality may be observed unless bear abundance is curbed by regulated harvest of bears occupying territories that extend beyond YNP. However, during 2005 the grizzly bear population in the Greater Yellowstone Ecosystem did not seem to increase significantly (Figs. 5, 6).

Predictions of future trends in northern Yellowstone elk abundance based on data collected since wolf restoration range from elk being maintained at low densities (i.e., 6,000-7,000 elk), in part because of predation, to elk numbers fluctuating around a mean of approximately 10,000 elk with long-term oscillations. The latter prediction was based on the assumption of selective and density-dependent predation providing a stabilizing influence that reduced the risk of severe elk population decline (Varley and Boyce 2006). The density of northern Yellowstone elk $\left(5-9 / \mathrm{km}^{2}\right)$ is within the range observed previously $\left(3-13.5 / \mathrm{km}^{2}\right.$; Coughenour and Singer 1996, Singer et al. 1997). Also, recent data (winter 2005-2006) show that calf recruitment on the northern range approximately doubled that of previous years (winters 2003-2004 and 2004-2005; winter calf:adult female counts; P. J. White, unpublished data; but see information on winter 2006-2007 calf:ad F ratio under Management Implications), possibly because of average weather conditions during spring 2005 and winter 2005-2006 where most calves winter (White and Garrott 2005b; Northern Yellowstone Cooperative Wildlife Working Group, unpublished data), a substantial reduction in the harvest (because the late harvest focuses on females [Lemke 2003], most of which are pregnant [Cook et al. 2004]), and a substantial decrease of wolves during 2005 due to poor pup survival (Smith et al. 2006b). Therefore, despite the relatively high elk calf mortality during our study, we do not expect the restoration of wolves to this ecosystem to extirpate elk or reduce them to consistently low numbers (i.e., $<4,000$, which the population has been above during the last 4 decades; Singer et al. 1997, White and Garrott 2005a) because of the demonstrated resiliency of the population after previous decreases in abundance due to management culls, hunter harvest, and winterkill, and the strength of density-related responses in survival and reproduction, potential functional and numerical responses of wolves, and use of alternate prey by wolves (Coughenour and Singer 1996, Taper and Gogan 2002, Varley and Boyce 2006).

\section{MANAGEMENT IMPLICATIONS}

Our findings have immediate relevance for natural resource managers in the Greater Yellowstone Area regarding the combined role of an intact, diverse predator guild at limiting an abundant prey population. The successful restoration of wolves into areas with already diverse large predator suites may necessitate rapid and substantial reductions in human harvests of female elk in some areas. Based largely on 4 consecutive years of low calf recruitment, the Montana Department of Fish, Wildlife, and Parks reduced the number of antler-less permits for the Gardiner Late Elk Hunt of northern Yellowstone elk by $>90 \%$ from 1,102 in 2005 to 104 in 2006 and 2007. This reduction essentially eliminated antler-less harvest as a significant factor decreasing elk numbers. Conservative harvest strategies will likely remain in effect for many years because the population has not responded with increased survival of prime-aged females (high reproductive value) and increased recruitment of calves into the breeding population. Instead, a count of 6,738 elk and a classification of 19 calves:100 adult females during winter 2007 reflect a continuing decrease in elk numbers and low recruitment (Northern Yellowstone Cooperative Wildlife Working Group, unpublished data).

There are limited options for managing predation inside YNP because park staff attempt to minimize human intervention while preserving or restoring fundamental biological processes (National Park Service 2006). Thus, populations of predators and prey are not controlled and reductions in human harvests of elk outside the park are one of the few available management tools. However, grizzly bears and wolves in the Greater Yellowstone Area were recently removed from the federal List of Endangered and Threatened Wildlife (Federal Register 2007, 2008). Delisting will provide managers outside the park with more flexibility to manipulate predators in certain areas through regulated harvests, including bears and wolves occupying ranges extending beyond park boundaries, which may somewhat alleviate additive mortality of elk calves (Smith et al. 2006a).

The spatial distribution of elk in the northern range seems to be shifting, with increased abundance in the lower-elevation northwestern portion of the range due to the potential spatial effects of differential calf summer survival and female age structure. Yellowstone National Park winter calf survival also 
likely varies similarly due to substantial differences in spatial distribution of wolves (Smith et al. 2006b). Furthermore, the age structure of adult female elk seems to vary across northern range of YNP, with older elk at higher elevations and younger elk at lower elevations (Houston 1982, Coughenour and Singer 1996, Cook et al. 2004). If calves demonstrate fidelity to their mothers' birthing areas and migration patterns, as is typical for large ungulates (Baker 1978, McCullough 1985), then the apparent spatial shift in the distribution of the population to lower-elevation areas outside the park may continue over time. This shift may be exacerbated by behavioral avoidance responses of elk to higher densities of wolves and deeper snows in the upper elevation areas of the winter range inside the park (Ripple et al. 2001, Fortin et al. 2006).

Elk in lower elevations outside the park are exposed to different management regimes (e.g., hunting), increased contact with humans, domestic animals, and croplands. Some potential issues regarding this segment of the elk population increasing include disease transmission (e.g., brucellosis) and crop damage. For example, every known brucellosis transmission to cattle in the Greater Yellowstone Ecosystem where the species could be reasonably assigned has been attributed to elk (Cheville et al. 1998, Galey et al. 2005). A shift of elk to lower elevations may also complicate efforts by the Montana Department of Fish, Wildlife, and Parks to maintain elk numbers within management objectives on portions of the winter range (e.g., north of Dome Mountain), even though overall population numbers have decreased by $>50 \%$ since 1995 . Thus, effective management of the northern winter range for elk and other ungulates will only be accomplished with strong partnerships that encourage the cooperative collection and sharing of information, discussion of alternate management approaches, and the implementation of proactive measures to conserve resources. The National Park Service should continue and expand their efforts to develop a collaborative vision and agenda for the northern range with their federal, state, and private partners.

Wolf restoration to YNP has been related to reductions in herbivore browsing, decreased elk competition with bighorn sheep, increased beaver (Castor canadensis) settlement, limited willow (Salix spp.) recovery, and an increase in food available to scavengers due to the remains of wolf-killed ungulates (Ripple et al. 2001, Smith et al. 2003, Wilmers et al. 2003, Smith and Ferguson 2005). Our findings suggest some of these apparent effects may not be the result of wolf restoration alone and ongoing research should consider the potential influence of bears, which have approximately tripled in abundance during the past 3 decades. This information will enable scientists to improve the explanatory power of existing wolf-ungulate models by incorporating the timing and spatial distribution of predation by bears and area-specific calf survival rates. In addition, assessments of the effects and effectiveness of wolf restoration into an already diverse large predator and herbivore guild, such as our study, will influence natural resource managers in other areas of North America (e.g., Mexico) or abroad (e.g., France, Italy, Scandanavia, Scotland, and Spain) that are either considering reintroductions of large predators or developing harvest recommendations because predators are increasing in density and recolonizing areas (Martínez-Meyer et al. 2006, Nilsen et al. 2007).

\section{ACKNOWLEDGMENTS}

We thank F. J. Singer for consultation and assistance during project design and implementation and for sharing data from the 1987-1990 northern Yellowstone elk calf study. We thank E. E. Albers, T. N. (Bedgood) Culberson, W. N. Bering, T. A. Caddy, T. Clark, B. A. Colasuonno, C. I. Crowe, T. L. Davis, V. T. Green, C. M. Hanson, T. O. Lemke, K. M. Loveless, M. L. St. Martin, W. P. Neighbors, D. A. Ravenel, and J. M. Smith for assisting with fieldwork. Hawkins \& Powers (Greybull, Wyoming) and Central Helicopters (Bozeman, Montana) conducted helicopter flights. D. A. Krapf, W. H. Hafer, and M. A. Wagner served as helicopter managers. D. C. Chapman and B. J. Walton (Montana Aircraft) conducted monitoring flights. T. O. Lemke assisted with aerial capture. N. J. Anderson performed necropsies, and tissue samples were analyzed by the State of Montana Department of Livestock Diagnostic Laboratory (Bozeman, MT). L. P. Waits and C. L. Anderson performed DNA analyses of predator hair and scat samples. K. P. Pilgrim performed DNA analyses on one predator hair and scat sample. J. C. Halfpenny trained our 2005 crew on predator hair identification. D. W. Smith, R. McIntyre, and the Yellowstone Wolf Project shared information on elk calf natality and mortality. Also, the Yellowstone Wolf Project graciously provided use of a vehicle each summer. K. A. Gunther and Yellowstone's Bear Management Office shared information regarding bear feeding behavior. We are grateful to J. C. Blanco and M. Crête for translating the abstract into Spanish and French, respectively. We thank D. E. Andersen, T. J. Kreeger, J. J. Meyer, J. K. Oakleaf, D. B. Siniff, D. W. Stephens, and one anonymous reviewer for critiquing earlier drafts of the manuscript. We are especially grateful to T. W. Arnold for providing significant assistance in analyzing survival data and using Program MARK.

\section{LITERATURE CITED}

Adams, L. G., F. J. Singer, and B. W. Dale. 1995. Caribou calf mortality in Denali National Park, Alaska. Journal of Wildlife Management 59:584-594.

Aguirre, A. A., D. E. Hansen, E. E. Starkey, and R. G. McLean. 1995. Serologic survey of wild cervids for potential disease agents in selected national parks in the United States. Preventive Veterinary Medicine 21:313-322.

Aguirre, A. A., and E. E. Starkey. 1994. Wildlife disease in U.S. National Parks: historical and coevolutionary perspectives. Conservation Biology 8:654-661.

Allee, W. C., A. E. Emerson, O. Park, T. Park, and K. P. Schmidt. 1949. Principles of animal ecology. Saunders, Philadelphia, Pennsylvania, USA.

Altmann, M. 1952. Social behavior of elk, Cervus canadensis nelsoni, in the Jackson Hole area of Wyoming. Behaviour 4:116-143.

Andersen, R., and J. D. C. Linnell. 1998. Ecological correlates of mortality of roe deer fawns in a predator-free environment. Canadian Journal of Zoology 76: 1217-1225.

Anderson, D. R., and K. P. Burnham. 2002. Avoiding pitfalls when using information-theoretic methods. Journal of Wildlife Management 66:912-918.

Baker, J. C. 1995. The clinical manifestations of bovine viral diarrhea infection. Veterinary Clinics of North America: Food Animal Practice 11:627-640.

Baker, R. R. 1978. The evolutionary ecology of animal migration. Holmes and Meier, New York, New York, USA.

Ballard, W. B., and V. Van Ballenberghe. 1997. Predator/prey relationships. Pages 247-273 in A. W. Franzmann and C. C. Schwartz, editors. Ecology and management of the North American moose. Smithsonian Institute Press, Washington, D.C., USA.

Ballard, W. B., J. S. Whitman, and C. L. Gardner. 1987. Ecology of an exploited wolf population in south-central Alaska. Wildlife Monographs 98. 
Ballard, W. B., J. S. Whitman, and D. J. Reed. 1991. Population dynamics of moose in south-central Alaska. Wildlife Monographs 114.

Bangs, E. E., and S. H. Fritts. 1996. Reintroducing the gray wolf to central Idaho and Yellowstone National Park. Wildlife Society Bulletin 24:402-413.

Barber, S. M., L. D. Mech, and P. J. White. 2005. Yellowstone elk calf mortality following wolf restoration-bears remain top summer predators. Yellowstone Science 13:37-44.

Barber-Meyer, S. M., C. R. Johnson, M. P. Murtaugh, L. D. Mech, and P. J. White. 2007a. Interleukin-6 and tumor necrosis factor- $\alpha$ values in elk neonates. Journal of Mammalogy 88:421-426.

Barber-Meyer, S. M., P. J. White, and L. D. Mech. 2007b. Selected pathogens and blood characteristics of northern Yellowstone elk. American Midland Naturalist 158:369-381.

Barmore, W. J. 2003. Ecology of ungulates and their winter range in northern Yellowstone National Park: research and synthesis 1962-1970. Yellowstone Center for Resources, Yellowstone National Park, Wyoming, USA.

Bear, G. D. 1989. Seasonal distribution and population characteristics of elk in Estes Valley, Colorado. Colorado Division of Wildlife, Special Report 651-12, Denver, USA.

Bender, L. C., E. Carlson, S. M. Schmitt, and J. B. Haufler. 2002. Production and survival of elk (Cervus elaphus) calves in Michigan. American Midland Naturalist 148:163-171.

Bergerud, A. T. 1974. The role of environment in the aggregation, movement and disturbance behaviour of the caribou. Pages 552-584 in V. Geist and F. Walther, editors. The behaviour of ungulates and its relationship to management: the papers of an international symposium, University of Calgary, 2-5 November 1972, Alberta, Canada. The World Conservation Union (IUCN), Morges, Switzerland.

Bertram, M. R., and M. T. Vivion. 2002. Moose mortality in eastern interior Alaska. Journal of Wildlife Management 66:747-756.

Boyce, M. S. 1993. Predicting the consequences of wolf recovery to ungulates in Yellowstone National Park. Pages 234-269 in R. S. Cook, editor. Ecological issues on reintroducing wolves into Yellowstone National Park. National Park Service Scientific Monograph NPS/NRYELL/NRSM-93/22. U.S. Department of the Interior, National Park Service, Denver, Colorado, USA.

Boyce, M. S., and J.-M. Gaillard. 1992. Wolves in Yellowstone, Jackson Hole, and the north fork of the Shoshone River: simulating ungulate consequences of wolf recovery. Pages 71-115 in J. D. Varley and W. G. Brewster, editors. Wolves for Yellowstone? A report to the United States Congress, research and analysis. Volume 4. U.S. Department of the Interior, National Park Service, Yellowstone National Park, Wyoming, USA.

Bunck, C. M., and K. H. Pollock. 1993. Estimating survival of radio-tagged birds. Pages 51-63 in J.-D. Lebreton and P. M. North, editors. Marked individuals in the study of bird populations. Birkhauser-Verlag, Basel, Switzerland.

Carl, G. R., and C. T. Robbins. 1988. The energetic cost of predator avoidance in ungulates: hiding versus following. Canadian Journal of Zoology 66:239-246.

Carstensen, M., G. D. DelGiudice, B. A. Sampson, and D. W. Kuehn. 2008. Survival and cause-specific mortality of white-tailed deer neonates relative to winter severity and nutritional condition of their dams. Journal of Wildlife Management 72:in press.

Carstensen Powell, M., G. D. DelGiudice, and B. A. Sampson. 2005. Low risk of marking-induced abandonment in free-ranging white-tailed deer neonates. Wildlife Society Bulletin 33:643-655.

Cheatum, E. L. 1949. Bone marrow as an index of malnutrition in deer. New York State Conservationist 3:19-22.

Cheville, N. F., D. R. McCulough, L. R. Paulson, N. Grossblatt, K. Iverson, and S. Parker. 1998. Brucellosis in the greater Yellowstone area. National Academy Press, Washington, D.C., USA.

Chouinard, M. P., and T. W. Arnold. 2007. Survival and habitat use of mallard (Anas platyrhynchos) broods in the San Joaquin Valley, California. Auk 124:13051316.

Clark, T. A., P. Curlee, S. C. Minta, and P. M. Kareiva, editors. 1999. Carnivores in ecosystems: the Yellowstone experience. Yale University Press, New Haven, Connecticut, USA.

Clutton-Brock, T. H., S. D. Albon, and F. E. Guinness. 1986. Great expectations: dominance, breeding success and offspring sex ratios in red deer. Animal Behaviour 34:460-471.

Clutton-Brock, T. H., F. E. Guinness, and S. D. Albon. 1982. Red deer: behavior and ecology of two sexes. University of Chicago Press, Chicago, Illinois, USA.

Cooch, E. G., and G. C. White. 2002. MARK: a gentle introduction. <http:// www.phidot.org/software/mark/docs/book>. Accessed 1 Sep 2005.

Cook, J. G., L. J. Quinland, L. L. Irwin, L. D. Bryant, R. A. Riggs, and J. W.
Thomas. 1996. Nutrition-growth relations of elk calves during late summer and fall. Journal of Wildlife Management 60:528-541.

Cook, R. C. 2000. Studies of body condition and reproductive physiology in Rocky Mountain elk. Thesis, University of Idaho, Moscow, USA.

Cook, R. C., J. G. Cook, and L. D. Mech. 2004. Nutritional condition of northern Yellowstone elk. Journal of Mammalogy 85:714-722.

Cook, R. D., and S. Weisberg. 1999. Applied regression including computing and graphics. John Wiley, New York, New York, USA.

Cook, R. S. 1993. Ecological issues on reintroducing wolves into Yellowstone National Park. National Park Service Scientific Monograph NPS/NRYELL/ NRSM-93/22. U.S. Department of the Interior, National Park Service, Denver, Colorado, USA.

Coughenour, M. B., and F. J. Singer. 1996. Elk population processes in Yellowstone National Park under the policy of natural regulation. Ecological Applications 6:573-583.

Cowan, I. McT. 1951. The disease and parasites of big game mammals of western Canada. Proceedings of the Annual British Columbia Game Convention 5:3764.

Crabtree, R. L., and J. W. Sheldon. 1999. Coyotes and canid coexistence in Yellowstone. Pages 127-164 in T. W. Clark, A. P. Curlee, S. C. Minta, and P. M. Kareiva, editors. Carnivores in ecosystems: the Yellowstone experience. Yale University Press, New Haven, Connecticut, USA.

Crête, M. 1998. Ecological correlates of regional variation in life history of the moose Alces alces: comment. Ecology 79:1836-1838.

Crête, M. 1999. The distribution of deer biomass in North America supports the hypothesis of exploitation ecosystems. Ecology Letters 2:223-227.

Darling, F. F. 1938. Bird flocks and breeding cycle. Cambridge University Press, Cambridge, United Kingdom.

Dekker, D., W. Bradfor, and J. R. Gunson. 1995. Elk and wolves in Jasper National Park, Alberta, from historical times to 1992. Pages 85-94 in L. N. Carbyn, S. H. Fritts, and D. R. Seip, editors. Ecology and conservation of wolves in a changing world. Canadian Circumpolar Institute, University of Alberta, Edmonton, Alberta, Canada.

Depner, K., O. J. B. Hubschle, and B. Liess. 1991. Prevalence of ruminant pestivrius infections in Namibia. Ondersterpoort Journal of Veterinary Research 58:107-109.

Despain, D. G. 1990. Yellowstone vegetation. Robert Rinehart, Boulder, Colorado, USA.

Despain, D. G., A. Rodman, P. Schullery, and H. Shovic. 1989. Burned area survey of Yellowstone National Park: the fires of 1988. Yellowstone National Park, Wyoming, USA.

Devries, J. H., J. J. Citta, M. S. Lindberg, D. W. Howerter, and M. G. Anderson. 2003. Breeding-season survival of mallard females in the prairie pothole region of Canada. Journal of Wildlife Management 67:551-563.

Ditchkoff, S. S., M. G. Sams, R. L. Lochmiller, and D. M. Leslie, Jr. 2001. Utility of necrosis factor- $\alpha$ and interleukin- 6 as predictors of neonatal mortality in white-tailed deer. Journal of Mammalogy 82:239-245.

Eberhardt, L. L. 1971. Population analysis. Pages 457-495 in R. H. Giles, editor. Wildlife management techniques. The Wildlife Society, Washington, D.C., USA.

Eberhardt, L. L. 1985. Assessing the dynamics of wild populations. Journal of Wildlife Management 49:997-1012.

Eberhardt, L. L. 2003. What should we do about hypothesis testing? Journal of Wildlife Management 67:241-247.

Eberhardt, L. L., P. J. White, R. A. Garrott, and D. B. Houston. 2007. A seventyyear history of trends in Yellowstone's northern elk herd. Journal of Wildlife Management 71:594-602.

Errington, P. L. 1946. Predation and vertebrate populations. The Quarterly Review of Biology 21:144-177.

Estes, R. D. 1976. The significance of breeding synchrony in the wildebeest. East African Wildlife Journal 14:135-152.

Estes, R. D., and R. K. Estes. 1979. The birth and survival of wildebeest calves. Zietschrift fur Tierpsychologie 50:45-95.

Estes, R. D., and J. Goddard. 1967. Prey selection and hunting behavior of the African wild dog. Journal of Wildlife Management 31:52-70.

Evans, S. B., L. D. Mech, D. W. Smith, P. J. White, and G. A. Sargeant. 2006. Survival and causes of mortality of cow elk in Yellowstone's northern range. Journal of Wildlife Management 70:1372-1378.

Farnes, P. E., C. Heydon, and K. Hansen. 1999. Snowpack distribution across Yellowstone National Park. Final report CA 1268-1-9017. Department of Earth Sciences, Montana State University, Bozeman, USA.

Federal Register. 2007. Part II, Department of the Interior, Fish and Wildlife 
Service, 50 CFR Part 17. Endangered and threatened wildlife and plants, designating the Greater Yellowstone Ecosystem population of grizzly bears as a distinct population segment, removing the Yellowstone distinct population segment of grizzly bears from the federal List of Endangered and Threatened Wildlife, proposed rule. Federal Register 72:14866-14938.

Federal Register. 2008. Department of the Interior, Fish and Wildlife Service, 50 CFR Part 17. Endangered and threatened wildlife and plants; final rule designating the northern Rocky Mountain population of gray wolf as a distinct population segment and removing this distinct population segment from the federal List of Endangered and Threatened Wildlife; final rule. Federal Register 73:10514-10560.

Felicetti, L. A., C. C. Schwartz, R. O. Rye, M. A. Haroldson, K. A. Gunther, and C. T. Robbins. 2003. Use of sulfur and nitrogen stable isotopes to determine the importance of whitebark pine nuts to Yellowstone grizzly bears. Canadian Journal of Zoology 81:763-770.

Findlay, C. R. 1973. Serum immune globulin levels in lambs under a week old. The Veterinary Record 92:530-532.

Flook, D. R. 1970. A study of sex differential in the survival of wapiti. Canada Wildlife Service Report, Serial Number 11. Queens Printer, Ottawa, Ontario, Canada.

Fortin, D., H. L. Beyer, M. S. Boyce, D. W. Smith, T. Duchesne, and J. S. Mao. 2006. Wolves influence elk movements: behavior shapes a trophic cascade in Yellowstone National Park. Ecology 86:1320-1330.

Franzmann, A. W. 1972. Environmental sources of variation of bighorn sheep physiologic values. Journal of Wildlife Management 36:924-932.

Frolich, K. 2000. Viral diseases of northern ungulates. Rangifer 20:83-97.

Gaillard, J. M., M. Festa-Bianchet, N. G. Yoccoz, A. Loison, and C. Toigo. 2000. Temporal variation in fitness components and population dynamics of large herbivores. Annual Review Ecological Systematics 31:367-393.

Galey, F., J. Bousman, T. Cleveland, J. Etchpare, R. Hendry, J. Hines, B. Lambert, J. Logan, S. Madden, B. Mead, K. Mills, K. Musgrave, D. Oldham, M. Olsen, T. Pollard, C. Purves, J. Snow, A. Sommers, T. Thorne, B. Wharff, B. Williams, B. Combs, W. Gern, J. Keck, T. Kreeger, R. Lance, B. Larson, E. Olson, D. O'Toole, D. Roberts, S. Werbelow, and A. Gertonson. 2005. Wyoming Brucellosis Coordination Team report and recommendations. Report presented to Governor Dave Freudenthal on January 11, 2005, Cheyenne, Wyoming, USA. $<$ http://agriculture.wy.gov/news/brucellosiscoordteam/brucellosiscoordrpt. pdf $>$. Accessed 10 Mar 2008.

Gannon, W. L., and R. S. Sikes, and the Animal Care and Use Committee of the American Society of Mammalogists. 2007. Guidelines of the American Society of Mammalogists for the use of wild mammals in research. Journal of Mammalogy 88:809-823.

Garner, G. W., K. R. Whitten, and F. J. Mauer. 1985. Methodology for studying neonatal mortality of caribou in remote areas. Pages 139-152 in T. C. Meredith and A. M. Martell, editors. Proceedings of Second North American Caribou Workshop. McGill University, Montreal, Quebec, Canada.

Garrott, R. A., L. L. Eberhardt, J. K. Otton, P. J. White, and M. A. Chaffee. 2002. A geochemical trophic cascade in Yellowstone's geothermal environments. Ecosystems 5:659-666.

Garrott, R. A., L. L. Eberhardt, P. J. White, and J. Rotella. 2003. Climate-induced variation in vital rates of an unharvested large-herbivore population. Canadian Journal of Zoology 81:33-45.

Gasaway, W. C., R. D. Boertje, D. V. Grangaard, D. G. Kelleyhouse, R. O. Stephenson, and D. G. Larsen. 1992. The role of predation in limiting moose at low densities in Alaska and Yukon and implications for conservation. Wildlife Monographs 120.

Gasaway, W. C., R. O. Stephenson, J. L. Davis, P. E. K. Shepherd, and O. E. Burris. 1983. Interrelationships of wolves, prey, and man in interior Alaska. Wildlife Monographs 84.

Geist, V. 2002. Adaptive behavioral strategies. Pages 389-433 in D. E. Toweill and J. W. Thomas, editors. North American elk: ecology and management. Smithsonian Institution Press, Washington, D.C., USA.

Goyal, S. M., M. A. Khan, S. W. McPherson, R. A. Robinson, and W. J. Boylan. 1988. Prevalence of antibodies to seven viruses in a flock of ewes in Minnesota. American Journal of Veterinary Research 49:464-467.

Gratson, M. W., and P. Zager. 1998. (Lochsa) Elk ecology. Study IV. Factors influencing elk calf recruitment. Federal Aid in Wildlife Restoration, Job Progress Report, Job 1 W-160-R-24. Idaho Department of Fish and Game, Boise, USA.

Greer, K. R. 1968. Special collections-Yellowstone elk study, 1967-68. Federal Aid in Wildlife Restoration, W-83-R-10. Montana Fish and Game Department Report, Montana Fish, Wildlife and Parks, Wildlife Division, Helena, USA.
Grimm, R. 1947. Coyote-bear relations. Yellowstone Nature Notes 21:45-46.

Guinness, F. E., T. H. Clutton-Brock, and S. D. Albon. 1978. Factors affecting calf mortality in red deer (Cervus elaphus). Journal of Animal Ecology 47:817832.

Gunther, K., and R. Renkin. 1990. Grizzly bear predation on elk calves and other fauna of Yellowstone National Park. International Conference on Bear Research and Management 8:329-334.

Guthery, F. S., L. A. Brennan, M. J. Peterson, and J. J. Lusk. 2005. Information theory in wildlife science: critique and viewpoint. Journal of Wildlife Management 69:457-465.

Hamer, D., and S. Herrero. 1991. Elk, Cervus elaphus, calves as food for grizzly bears, Ursus arctos, in Banff National Park, Alberta. The Canadian FieldNaturalist 105:101-103.

Hamilton, W. D. 1971. The geometry of the selfish herd. Journal of Theoretical Biology 31:295-311.

Hamlin, K. L. 2006. Monitoring and assessment of wolf-ungulate interactions and population trends within the Greater Yellowstone Area, Southwestern Montana, and Montana statewide. Federal Aid in Wildlife Restoration Project, W-120-R. Montana Fish, Wildlife and Parks, Wildlife Division, Helena, USA.

Hamlin, K. L., and M. S. Ross. 2002. Effects of hunting regulation changes on elk and hunters in the Gravelly-Snowcrest Mountains, Montana. Federal Aid in Wildlife Restoration Project, W-120-R-April 2002. Montana Fish, Wildlife and Parks, Wildlife Division, Helena, USA.

Harder, J. D., and R. L. Kirkpatrick. 1994. Physiological methods in wildlife research. Pages 275-306 in T. A. Bookhout, editor. Research and management techniques for wildlife and habitats. Fifth edition. The Wildlife Society, Bethesda, Maryland, USA.

Harker, D. B. 1974. Serum immune globulin levels in artificially reared lambs. Veterinary Record 95:229-231.

Haroldson, M. A. 2006. Unduplicated females. Pages 11-16 in C. C. Schwartz, M. A. Haroldson and K. West, editors. Yellowstone grizzly bear investigations: annual report of the Interagency Grizzly Bear Study Team, 2005. U.S. Geological Survey, Bozeman, Montana, USA.

Haroldson, M. A., and K. Frey. 2005. Grizzly bear mortalities. Pages 24-29 in C. C. Schwartz and M. A. Haroldson, editors. Yellowstone grizzly bear investigations: annual report of the Interagency Grizzly Bear Study Team, 2005. U.S. Geological Survey, Bozeman, Montana, USA.

Haroldson, M. A., R. A. Swalley, S. Podruzny, C. C. Schwartz, M. Ternet, G. Holm, and D. Moody. 1998. Page 12 in Yellowstone grizzly bear investigations: report of the Interagency Grizzly Bear Study Team, 1997. U.S. Geological Survey, Bozeman, Montana, USA.

Harris, N. C. 2007. Monitoring survival of young in ungulates: a case study with Rocky Mountain elk. Thesis, University of Montana, Missoula, USA.

Haugen, A. O., and W. Speake. 1958. Determining the age of young white-tailed deer. Journal of Wildlife Management 22:319-321.

Hayes, R. D., R. Farnell, R. M. P. Ward, J. Carey, M. Dehn, G. W. Kuzyk, A. M. Baer, C. L. Gardner, and M. O'Donoghue. 2003. Experimental reduction of wolves in the Yukon: ungulate responses and management implications. Wildlife Monographs 152.

Hayes, R. D., and A. S. Harestad. 2000. Wolf functional response and regulation of moose in the Yukon. Canadian Journal of Zoology 78:60-66.

Hirst, S. M. 1965. Ecological aspects of big game predation. Fauna and Flora 16:315.

Honess, R. F., and K. B. Winter. 1956. Diseases of wildlife in Wyoming. Bulletin 9. Wyoming Game and Fish Commission, Laramie, Wyoming, USA.

Hornocker, M. G. 1970. An analysis of mountain lion predation upon mule deer and elk in the Idaho primitive area. Wildlife Monographs 21.

Houston, D. B. 1979. The northern Yellowstone elk: winter distribution and management. Pages 263-272 in M. S. Boyce and L. D. Hayden-Wing, editors. North American elk: ecology, behavior and management. University of Wyoming, Laramie, USA.

Houston, D. B. 1982. The northern Yellowstone elk: ecology and management. Macmillian, New York, New York, USA.

Hubbert, W. T., J. H. Bryner, A. L. Fernelitus, G. H. Frank, and P. C. Estes. 1973. Viral infection of the bovine fetus and its environment. Archives of Virology 41:86-98.

Hurvich, C. M., and C.-L. Tsai. 1995. Model selection for extended quasilikelihood models in small samples. Biometrics 51:1077-1084.

International Species Information System [ISIS]. 2002. Cervus elaphus, red deer, both sexes $\leq 8$ days old, Apple Valley, Minnesota. $<$ http://www.isis.org/>. Accessed 6 Jan 2006.

Irwin, L. L. 2002. Migration. Pages 493-513 in D. E. Toweill and J. W. Thomas, 
editors. North American elk: ecology and management. Smithsonian Institution Press, Washington, D.C., USA.

Jenkins, K. J., and N. L. Barten. 2005. Demography and decline of the Mentasta caribou herd in Alaska. Canadian Journal of Zoology 83:1174-1188.

Johnson, D. E. 1951. Biology of the elk calf, Cervus canadensis nelsoni. Journal of Wildlife Management 15:396-410.

Kadane, J. B., and N. A. Lazar. 2004. Methods and criteria for model selection. Journal of the American Statistical Association 99:279-290.

Kahrs, R. F. 1977. Infectious bovine rhinotracheitis: a review and update. Journal of the American Veterinary Medical Association 171:1055-1064.

Keech, M. A., R. T. Bowyer, J. M. Ver Hoef, R. D. Boertje, B. W. Dale, and T. R. Stephenson. 2000. Life-history consequences of maternal condition in Alaskan moose. Journal of Wildlife Management 64:450-462.

Kingscote, B. F., W. D. G. Yates, and G. B. Tiffin. 1987. Diseases of wapiti utilizing cattle range in southwestern Alberta. Journal of Wildlife Diseases 23: 86-91.

Krebs, C. J. 1999. Ecological methodology. Second edition. Addison Wesley Longman, Menlo Park, California, USA.

Kruuk, H. 1964. Predators and anti-predation behavior of the black-headed gull (Larus ridibundus). Behaviour (Supplement 11):1-129. Brill, Leiden, The Netherlands.

Kruuk, H. 1972. The spotted hyena: a study of predation and social behavior. University of Chicago Press, Chicago, Illinois, USA.

Kunkel, K. E., and L. D. Mech. 1994. Wolf and bear predation on white-tailed deer fawns in northeastern Minnesota. Canadian Journal of Zoology 72:15571565.

Kunkel, K. E., and D. H. Pletscher. 1999. Species-specific population dynamics of cervids in a multipredator system. Journal of Wildlife Management 63:10821093.

Larsen, D. G., D. A. Gauthier, and R. L. Markel. 1989. Causes and rates of mortality of moose in southwestern Yukon. Journal of Wildlife Management 53 548-557.

Lemke, T. O. 2003. Gardiner late elk hunt annual report. Montana Fish, Wildlife and Parks, Livingston, USA.

Lemke, T. O. 2005. Spring 2005 ungulate carcass count. Montana Fish, Wildlife and Parks, Livingston, USA.

Lemke, T. O., J. A. Mack, and D. B. Houston. 1998. Winter range expansion by the northern Yellowstone elk herd. Intermountain Journal of Sciences 4:1-9.

Lent, P. C. 1974. Mother-infant relationships in ungulates. Pages 14-55 in V. Geist, and F. Walther, editors. The behaviour of ungulates and its relation to management. International Union for the Conservation of Nature, Morges, Switzerland.

LeResche, R. E., U. S. Seal, P. D. Karns, and A. W. Franzmann. 1974. A review of blood chemistry of moose and other Cervidae, with emphasis on nutritional assessment. Le Naturaliste Canadien 101:263-290.

Linnell, J. D. C., R. Aanes, and R. Andersen. 1995. Who killed Bambi? The role of predation in the neonatal mortality of temperate ungulates. Wildlife Biology 1: 209-223.

Logan, E. F., and T. Gibson. 1975. Serum immunoglobulin levels in suckled beef calves. Veterinary Record 97:229-230.

Loudon, A. S. I. 1985. Lactation and neonatal survival of mammals. Symposium of the Zoological Society London 54:183-207.

Mack, J. A., and F. J. Singer. 1992. Predicted effects of wolf predation on northern range elk, mule deer, and moose using Pop-II models. Pages 43-70 in J. D. Varley and W. G. Brewster, editors. Wolves for Yellowstone? A report to the United States Congress, research and analysis. Volume 4. U.S. Department of the Interior, National Park Service, Yellowstone National Park, Wyoming, USA.

Mack, J. A., and F. J. Singer. 1993a. Using Pop-II models to predict effects of wolf predation and hunter harvests on elk, mule deer, and moose on the northern range. Pages 49-74 in R. S. Cook, editor. Ecological issues on reintroducing wolves into Yellowstone National Park. National Park Service Scientific Monograph NPS/NRYELL/NRSM-93/22. U.S. Department of the Interior, National Park Service, Denver, Colorado, USA

Mack, J. A., and F. J. Singer. 1993b. Population models for elk, mule deer, and moose on Yellowstone's northern winter range. Pages 270-305 in R. S. Cook, editor. Ecological issues on reintroducing wolves into Yellowstone National Park. National Park Service Scientific Monograph NPS/NRYELL/NRSM-93/ 22. U.S. Department of the Interior, National Park Service, Denver, Colorado, USA.

Martin, W. B. 1996. Respiratory infections of sheep. Comparative Immunology, Microbiology, and Infectious Diseases 19:171-179.

Martínez-Meyer, E., A. T. Peterson, J. I. Servin, and L. F. Kiff. 2006. Ecological niche modeling and prioritizing areas for species reintroductions. Oryx 40:411418.

Mattson, D. J. 1997. Use of ungulates by Yellowstone grizzly bears Ursus arctos. Biological Conservation 81:161-177.

Mattson, D. J., C. M. Gillin, S. A. Benson, and R. R. Knight. 1991. Bear use of alpine insect aggregations in the Yellowstone ecosystem. Canadian Journal of Zoology 69:2430-2435.

McCullough, D. R. 1985. Long range movements of large terrestrial animals. Contributions in Marine Science Supplement 27:444-465.

McGuire, T. C., N. E. Pfeiffer, J. M. Weikel, and R. C. Gartsch. 1976. Failure of colostral immunoglobulin transfer in calves dying from infectious disease. Journal of American Veterinary Medical Association 169:713-718.

Meagher, M. M. 1974. Yellowstone's bison-a unique wild heritage. National Parks and Conservation Magazine May:9-14.

Mech, L. D. 1970. The wolf: the ecology and behavior of an endangered species. Doubleday, New York, New York, USA.

Mech, L. D. 2007. Femur-marrow fat of white-tailed deer fawns killed by wolves. Journal of Wildlife Management 71:920-923.

Mech, L. D., L. G. Adams, T. J. Meier, J. W. Burch, and B. W. Dale. 1998. The wolves of Denali. University of Minnesota Press, Minneapolis, USA.

Mech, L. D., and P. D. Karns. 1977. Role of the wolf in a deer decline in the Superior National Forest. U.S. Department of Agriculture Forest Service Research Paper NC-148, North Central Forest Experimental Station, St. Paul, Minnesota, USA.

Mech, L. D., and R. E. McRoberts. 1990. Survival of white tailed deer fawns in relation to maternal age. Journal of Mammalogy 71:465-467.

Mech, L. D., and R. O. Peterson. 2003. Wolf-prey relationships. Pages 131-161 in L. D. Mech, and L. Boitani, editors. Wolves: behavior, ecology, and conservation. University of Chicago Press, Chicago, Illinois, USA.

Mech, L. D., D. W. Smith, K. M. Murphy, and D. R. MacNulty. 2001. Winter severity and wolf predation on a formerly wolf-free elk herd. Journal of Wildlife Management 65:998-1003.

Messier, F. 1994. Ungulate population models with predation: a case study with the North American moose. Ecology 75:478-488.

Messier, F., W. C. Gasaway, and R. O. Peterson. 1995. Wolf-ungulate interactions in the Northern Range of Yellowstone: hypotheses, research priorities, and methodologies. Midcontinent Ecological Science Center, National Biological Service, Fort Collins, Colorado, USA.

Moore, T. D., L. E. Spence, and C. G. Dugnolle. 1974. Identification of dorsal guard hairs of some mammals of Wyoming. Bulletin 14. Wyoming Game Fish Department, Cheyenne, Wyoming, USA

Murie, O. L. 1951. The elk of North America. Stackpole, Harrisburg, Pennsylvania, USA.

Murphy, K. M. 1998. The ecology of the cougar (Puma concolor) in the northern Yellowstone ecosystem: interactions with prey, bears, and humans. Dissertation, University of Idaho, Moscow, USA.

Myers, W. L., B. Lyndaker, P. E. Fowler, and W. Moore. 1996. Investigations of calf elk mortalities in southeast Washington: a progress report 1992-1996. Washington Department of Wildlife, Olympia, USA.

National Climate Data Center. 2005. Palmer Drought Survey Index (PDSI), Wyoming Division 1. <http://www.cpc.ncep.noaa.gov/products/ monitoring_and_data/drought.shtml $>$. Accessed 11 Sep 2005.

National Climate Data Center. 2006a. Precipitation, Wyoming Division 1. $<$ http://www.cpc.ncep.noaa.gov/products/monitoring_and_data/us_prec. shtml >. Accessed 2 Apr 2006.

National Climate Data Center. 2006b. Temperature, Wyoming Division 1. $<$ http://www.cpc.ncep.noaa.gov/products/monitoring_and_data/us_prec. shtml>. Accessed 2 Apr 2006.

National Park Service. 2006. Management policies. U.S. Department of the Interior, National Park Service, Washington, D.C., USA.

National Research Council. 2002. Ecological Dynamics on Yellowstone's Northern Range. The National Academies Press, Washington, D.C., USA.

Nelson, M. E., and L. D. Mech. 2006. A 3-decade dearth of deer (Odocoileus virginianus) in a wolf (Canis lupus)-dominated ecosystem. American Midland Naturalist 155:373-382.

Nelson, T. A., and A. Woolf. 1987. Mortality of white-tailed deer fawns in southern Illinois. Journal of Wildlife Management 51:326-329.

Neter, J., M. H. Kutner, C. J. Nachtsheim, and W. Wasserman. 1996. Applied linear statistical models. Fourth edition. WCB McGraw-Hill, New York, New York, USA.

Nilsen, E. B., E. J. Milner-Gulland, L. Schofield, A. Mysterud, N. C. Stenseth, and T. Coulson. 2007. Wolf reintroduction to Scotland: public attitudes and 
consequences for red deer management. Proceedings of the Royal Society B 274: 995-1002.

Noyes, J. H., B. K. Johnson, L. D. Bryant, S. L. Findholt, and J. W. Thomas. 1996. Effects of bull age on pregnancy rates and conception dates of cow elk. Journal of Wildlife Management 60:508-517.

O'Gara, B. W. 1978. Differential characteristics of predator kills. Proceedings of Antelope States Workshop 8:380-393.

Ozoga, J. J., and L. J. Verme. 1986. Relation of maternal age to fawn-rearing success in white-tailed deer. Journal of Wildlife Management 50:480-486.

Palmer, W. C. 1965. Meterological drought. U.S. Weather Bureau Research Paper 45. National Oceanic and Atmospheric Administration Library and Information Services Division, Washington, D.C., USA.

Paquet, P. C., and R. K. Brook. 2004. From the field: island use as an anti-predator tactic by parturient elk and nursery herds in Riding Mountain National Park, Manitoba. Wildlife Society Bulletin 32:1321-1324.

Phillips, M. P., and D. W. Smith. 1996. The wolves of Yellowstone. Voyageur Press, Stillwater, Minnesota, USA.

Pimlott, D. H. 1967. Wolf predation and ungulate populations. American Zoologist 7:267-278.

Pojar, T., and D. C. Bowden. 2004. Neonatal mule deer fawn survival in westcentral Colorado. Journal of Wildlife Management 68:550-560.

Pollock, K. H., S. R. Winterstein, C. M. Bunck, and P. D. Curtis. 1989. Survival analysis in telemetry studies: the staggered entry design. Journal of Wildlife Management 53:7-15.

Pulliam, H. R., and T. R. Caraco. 1984. Living in groups: is there an optimal group size? Pages 122-147 in J. R. Krebs, and N. B. Davies, editors. Behavioural ecology: an evolutionary approach. Second edition. Sinauer, Sunderland, Massachusetts, USA.

Raithel, J. D. 2005. Calf elk survival in west-central Montana and its impact on population dynamics. Thesis, University of Montana, Missoula, USA.

Raithel, J. D., M. K. Kauffman, and D. H. Pletscher. 2007. Impact of spatial and temporal variation in calf survival on the growth of elk populations. Journal of Wildlife Management 71:795-803.

Reynolds, H. B. 1950. The law of the wild. Yellowstone Nature Notes 24:44-45. Rhyan, J. C., K. Aune, D. R. Ewalt, J. Marquardt, J. W. Mertins, J. B. Payeur, D. A. Saari, P. Schladweiler, E. J. Sheehan, and D. Worley. 1997. Survey of freeranging elk from Wyoming and Montana for selected pathogens. Journal of Wildlife Diseases 33:290-298.

Ripple, W. J., E. J. Larsen, R. A. Renkin, and D. W. Smith. 2001. Trophic cascades among wolves, elk and aspen on Yellowstone National Park's northern range. Biological Conservation 102:227-234.

Roy, L. L., and M. J. Dorrance. 1976. Methods of investigating predation of domestic livestock: a manual for investigating officers. Alberta Agriculture, Edmonton, Alberta, Canada.

Rush, W. M. 1932. Bang's disease in the Yellowstone National Park buffalo and elk herds. Journal of Mammalogy 13:371-372.

Rust, H. J. 1946. Mammals of northern Idaho. Journal of Mammalogy 27:308327.

Rutberg, A. T. 1987. Adaptive hypotheses of birth synchrony in ruminants: an interspecific test. American Naturalist 130:692-710.

Ruth, T. K. 2004. "Ghost of the Rockies"-the Yellowstone cougar project. Yellowstone Science 12:13-24.

Sadlier, R. M. 1969. The ecology of reproduction in wild and domesticated mammals. Methuen, London, United Kingdom.

Sæther, B.-E., and R. Andersen. 1996. Ecological correlates of regional variation in life history of the moose Alces alces. Ecology 77:1493-1500.

Sauer, J. R., and M. S. Boyce. 1983. Density dependence and survival of elk in northwestern Wyoming. Journal of Wildlife Management 47:31-37.

Schaller, G. B. 1967. Hunting behavior of the cheetah in the Serengeti National Park. East African Wildlife Journal 6:95-100.

Schaller, G. B. 1972. The Serengeti lion: a study of predator-prey relations. University of Chicago Press, Chicago, Illinois, USA.

Schlegel, M. 1976. Factors affecting calf elk survival in north central Idaho. A progress report. Proceedings of the Western Association of State Game Fish Commission 56:342-355.

Schwartz, C. C., M. A. Haroldson, G. C. White, R. B. Harris, S. Cherry, K. A. Keating, D. Moody, and C. Servheen. 2006. Temporal, spatial, and environmental influences on the demographics of grizzly bears in the Greater Yellowstone Ecosystem. Wildlife Monographs 161.

Seal, U. S., M. E. Nelson, L. D. Mech, and R. L. Hoskinson. 1978. Metabolic indicators of habitat differences in four Minnesota deer populations. Journal of Wildlife Management 42:746-754.
Seal, U. S., J. J. Ozoga, A. W. Erickson, and L. J. Verme. 1972. Effects of immobilization on blood analyses of white-tailed deer. Journal of Wildlife Management 36:1034-1040.

Sekulic, R. 1978. Seasonality of reproduction in sable antelope. East African Wildlife Journal 16:177-182.

Shupe, J. L., A. E. Olson, H. B. Peterson, and J. B. Low. 1984. Fluoride toxicosis in wild ungulates. Journal of the American Veterinary Medical Association 185: $1295-1300$

Sinclair, A. R. E., S. A. R. Mduma, and P. Arcese. 2000. What determines phenology and synchrony of ungulate breeding in Serengeti? Ecology 81:21002111.

Singer, F. J., A. Harting, K. K. Symonds, and M. B. Coughenour. 1997. Density dependence, compensation, and environmental effects on elk calf mortality in Yellowstone National Park. Journal of Wildlife Management 61:12-25.

Singer, F. J., W. Schreier, J. Oppenheim, and E. O. Garton. 1989. Drought, fires, and large mammals. BioScience 39:716-722.

Smith, B. L., and S. H. Anderson. 1996. Patterns of neonatal mortality of elk in northwest Wyoming. Canadian Journal of Zoology 74:1229-1237.

Smith, B. L., and S. H. Anderson. 1998. Juvenile survival and population regulation of the Jackson elk herd. Journal of Wildlife Management 62:10361045.

Smith, B. L., R. L. Robbins, and S. H. Anderson. 1996. Adaptive sex ratios: another example? Journal of Mammalogy 77:818-825.

Smith, B. L., R. L. Robbins, and S. H. Anderson. 1997. Early development of supplementally fed, free-ranging elk. Journal of Wildlife Management 61:27-39.

Smith, B. L., E. S. Williams, K. C. McFarland, T. L. McDonald, G. Wang, and T. D. Moore. 2006a. Neonatal mortality of elk in Wyoming: environmental, population, and predator effects. U.S. Department of Interior, U.S. Fish and Wildlife Service, Biological Technical Publication BTP-R6007-2006, Washington D.C., USA.

Smith, D. W. 2005. Ten years of Yellowstone wolves. Yellowstone Science 13:733.

Smith, D. W., T. D. Drummer, K. M. Murphy, D. S. Guernsey, and S. B. Evans. 2004. Winter prey selection and estimation of wolf kill rates in Yellowstone National Park, 1995-2000. Journal of Wildlife Management 68:153-166.

Smith, D. W., and G. Ferguson. 2005. Decade of the wolf: returning the wild to Yellowstone. The Lyons Press, Guilford, Connecticut, USA.

Smith, D. W., R. O. Peterson, and D. B. Houston. 2003. Yellowstone after wolves. BioScience 53:330-340.

Smith, D. W., D. R. Stahler, and D. S. Guernsey. 2005. Yellowstone Wolf Project: annual report, 2004. YCR-NR-2005-02. National Park Service, Yellowstone Center for Resources, Yellowstone National Park, Wyoming, USA.

Smith, D. W., D. R. Stahler, and D. S. Guernsey. 2006b. Yellowstone Wolf Project: annual report, 2005. YCR-NR-2006-04. National Park Service, Yellowstone Center for Resources, Yellowstone National Park, Wyoming, USA.

Smith, K. C. 1997. Herpesviral abortion in domestic animals. Veterinary Journal (London) 153:253-268.

Smits, J. E. G. 1992. Elk disease survey in western Canada and northwestern United States. Pages 101-106 in R. D. Brown, editor. The biology of deer. Springer-Verlag, New York, New York, USA.

Stephens, D. W., and J. R. Krebs. 1986. Foraging theory. Princeton University Press, Princeton, New Jersey, USA.

Storz, J., X. Lin, C. W. Purdy, V. N. Chouljenko, K. G. Kousoulas, F. M. Enright, W. C. Gilmore, R. E. Briggs, and R. W. Loan. 2000. Coronavirus and Pasteurella infections in bovine shipping fever pneumonia and Evan's criteria for causation. Journal of Clinical Microbiology 38:3291-3298.

Taper, M. L., and P. J. P. Gogan. 2002. The northern Yellowstone elk: density dependence and climatic conditions. Journal of Wildlife Management 66:106122

Tessaro, S. V., P. S. Carman, and D. Deregt. 1999. Viremia and virus shedding in elk infected with type 1 and virulent type 2 bovine viral diarrhea virus. Journal of Wildlife Diseases 35:671-677.

Testa, J. W. 2002. Does predation on neonates inherently select for earlier births? Journal of Mammalogy 83:699-706.

Thorne, E. T., R. E. Dean, and W. G. Hepworth. 1976. Nutrition during gestation in relation to successful reproduction in elk. Journal of Wildlife Management 40:330-335.

Thorne, E. T., E. S. Williams, W. M. Samuel, and T. P. Kistner. 2002. Diseases and parasites. Pages 351-387 in D. E. Toweill, and J. W. Thomas, editors. North American elk: ecology and management. Smithsonian Institution Press, Washington, D.C., USA 
Thrusfield, M. 2005. Veterinary epidemiology. Third edition. Blackwell Science, Oxford, United Kingdom.

Trivers, R. L., and D. E. Willard. 1973. Natural selection of parental ability to vary the sex ratio of offspring. Science 179:90-92.

Tunnicliff, E. A., and H. Marsh. 1935. Bang's disease in bison and elk in the Yellowstone National Park and on the National Bison Range. Journal of the American Veterinary Medical Association 86:745-752.

U.S. Fish and Wildlife Service. 1994. The reintroduction of gray wolves to Yellowstone National Park and central Idaho: final environmental impact statement. U.S. Fish and Wildlife Service, Helena, Montana, USA.

U.S. Fish and Wildlife Service, Nez Perce Tribe, National Park Service, Montana Fish, Wildlife and Parks, Idaho Fish and Game, and USDA Wildlife Services. 2005. Rocky Mountain Wolf Recovery 2004 annual report. D. Boyd, editor. U.S. Fish and Wildlife Service, Ecological Services, Helena, Montana, USA.

Valkenburg, P., M. E. McNay, and B. W. Dale. 2004. Calf mortality and population growth in the Delta caribou herd after wolf control. Wildlife Society Bulletin 32:746-756.

Varley, J. D., and W. G. Brewster, editors. 1992. Wolves for Yellowstone? A report to the United States Congress, research and analysis. Volume 4. National Park Service, Yellowstone National Park, Wyoming, USA.

Varley, N., and M. S. Boyce. 2006. Adaptive management for reintroductions. Updating a wolf recovery model for Yellowstone National Park. Ecological Modeling 193:315-339.

Vihan, V. S. 1988. Immunoglobulin levels and their effect on neonatal survival in sheep and goats. Small Ruminant Research 1:135-144.

Vikoren, T., and G. Stuve. 1996. Fluoride exposure in cervids inhabiting areas adjacent to aluminum smelters in Norway 11. Fluorosis. Journal of Wildlife Diseases 32:181-189.

Vreeland, J. K., D. R. Diefenbach, and B. D. Wallingford. 2004. Survival rates, mortality causes, and habitats of Pennsylvania white-tailed deer fawns. Wildlife Society Bulletin 32:542-553

Vucetich, J. A., D. W. Smith, and D. R. Stahler. 2005. Influence of harvest, climate, and wolf predation on Yellowstone elk, 1961-2004. Oikos 111:259-270.

Wade, D. A., and J. E. Bowns. 1985. Procedures for evaluating predation on livestock and wildlife. Bulletin Number B-1429, Texas Agricultural Extension Service, Texas A\&M University, San Angelo, USA.

Weaver, J. 1978. The wolves of Yellowstone. Natural Resources Report no. 14. National Park Service, Washington, D.C., USA

Wesson, J. A., III., P. F. Scanlon, R. L. Kirkpatrick, H. S. Mosby, and R. L. Butcher. 1979. Influence of chemical immobilization and physical restraint on steroid hormone levels in blood of white-tailed deer. Canadian Journal of Zoology 57:768-776.
White, G. C., and K. P. Burnham. 1999. Program MARK: survival estimation from populations of marked animals. Bird Study 46:S120-S139.

White, G. C., and R. M. Garrott. 1990. Analysis of wildlife radio-tracking data. Academic Press, New York, New York, USA.

White, P. J., and R. A. Garrott. 2005a. Northern Yellowstone elk after wolf restoration. Wildlife Society Bulletin 33:942-955.

White, P. J., and R. A. Garrott. 2005b. Yellowstone's ungulates after wolvesexpectations, realizations, and predictions. Biological Conservation 125:141-152.

White, P. J., R. A. Garrott, and L. L. Eberhardt. 2003. Evaluating the consequences of wolf recovery on northern Yellowstone elk, YCR-NR-200402. U.S. Department of Interior National Park Service, Yellowstone Center for Resources, Yellowstone National Park, Wyoming, USA.

Whitten, K. R., G. W. Garner, F. J. Mauer, and R. B. Harris. 1992. Productivity and early calf survival in the Porcupine Caribou herd. Journal of Wildlife Management 56:201-212.

Wilmers, C., R. Crabtree, D. Smith, K. Murphy, and W. Getz. 2003. Trophic facilitation by introduced top predators: grey wolf subsidies to scavengers in Yellowstone National Park. Journal of Animal Ecology 72:909-916.

Wissel, C., and R. Brandl. 1988. A model for the adaptive significance of partial reproductive synchrony within social units. Evolutionary Ecology 2:102-114.

Worley, D. E., and R. E. Barrett. 1964. Studies on the parasites of the northern Yellowstone elk herd and a suggested program for its restoration. Yellowstone files, Yellowstone National Park, Wyoming, USA.

Wright, G. J. 2003. An analysis of the northern Yellowstone elk herd: population reconstruction and selection of elk by wolves and hunters. Thesis, Michigan Technological University, Houghton, USA.

Yates, W. D. 1982. A review of infectious bovine rhinotracheitis, shipping fever pneumonia and viral-bacterial synergism in respiratory disease of cattle. Canadian Journal of Comparative Medicine 46:225-263.

Yellowstone National Park, U.S. Fish and Wildlife Service, University of Wyoming, University of Idaho, Interagency Grizzly Bear Study Team, University of Minnesota Cooperative Park Studies Unit. 1990. Wolves for Yellowstone? A report to the United States Congress, vol. 1: executive summary; vol. 2: research and analysis. National Park Service, Yellowstone National Park, Wyoming, USA.

Zager, P., C. White, and G. Pauley. 2005. Elk ecology. Study IV. Factors influencing elk calf recruitment. Job \#s 1-3. Pregnancy rates and condition of cow elk. Calf mortality causes and rates. Predation effects on elk calf recruitment. Federal Aid in Wildlife Restoration, Job Progress Report, W-160-R-32, Subproject 31. Idaho Department of Fish and Game, Boise, USA.

Received: 7 August 2006

Accepted: 5 November 2007 


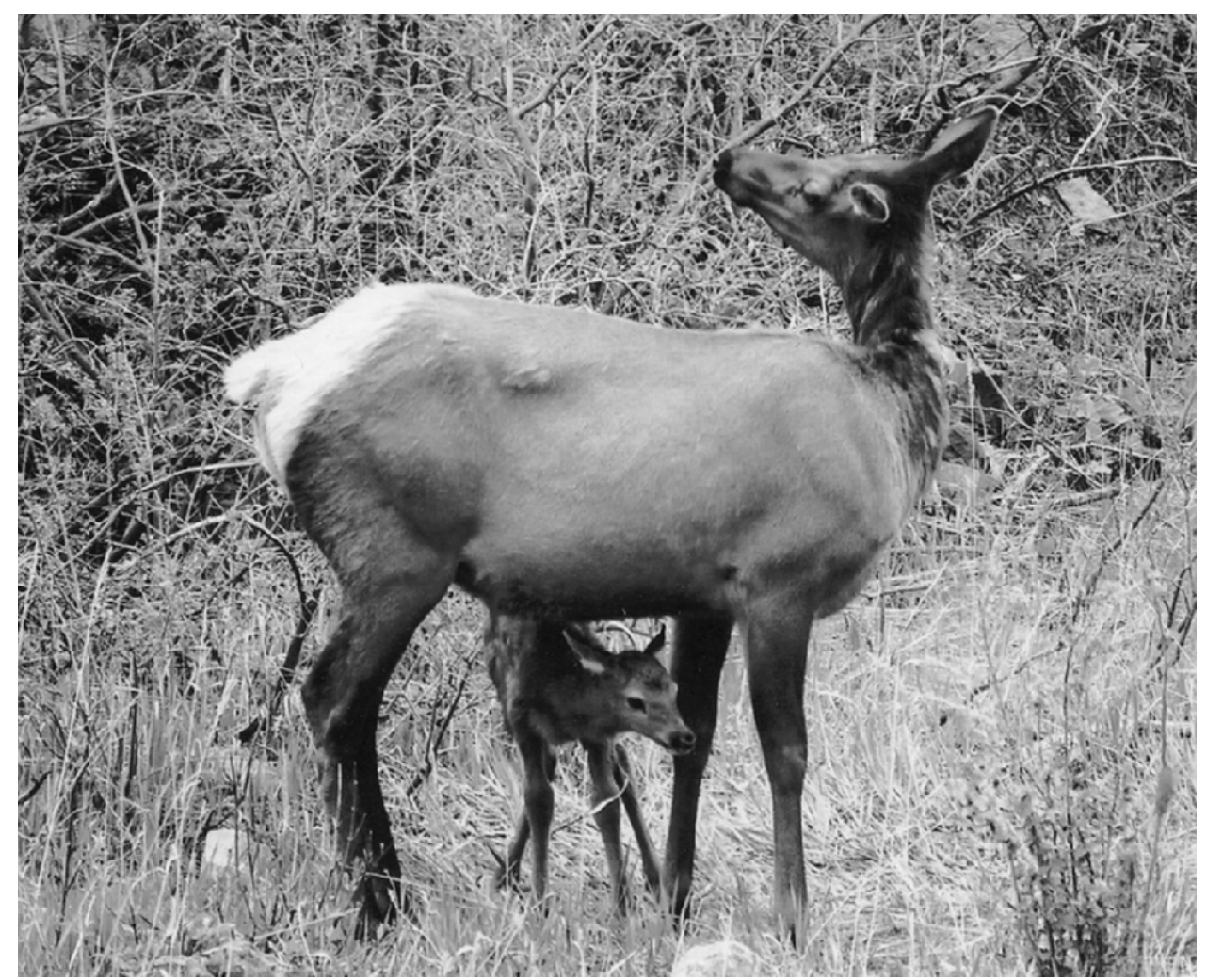

An elk calf stands under its watchful mother in Yellowstone National Park. Photo by Chris I. Crowe. 